Thaís Fonseca Rech

Improving the classification of data deficient species in Red Lists: the case of the trigonal clam Tivela mactroides (Born, 1778) (Bivalvia) in São Paulo State

\begin{abstract}
Dissertação apresentada ao Instituto Oceanográfico da Universidade de São Paulo, como parte dos requisitos para obtenção do título de Mestre em Ciências, Programa de Oceanografia, na área de Oceanografia Biológica.
\end{abstract}

Orientador: Prof. Dr. Alexander Turra 
Universidade de São Paulo

Instituto Oceanográfico

\section{Improving the classification of data deficient species in Red Lists: the case of the trigonal clam Tivela mactroides (Born, 1778) (Bivalvia) in São Paulo State}

\section{(VERSÃO CORRIGIDA)}

Thaís Fonseca Rech

Dissertação apresentada ao Instituto Oceanográfico da Universidade de São Paulo, como parte dos requisitos para obtenção do título de Mestre em Ciências, área de Oceanografia Biológica.

Julgada em

$\operatorname{Prof}(\mathrm{a}) . \operatorname{Dr}(\mathrm{a}) . \quad$ Conceito

$\operatorname{Prof}(\mathrm{a}) . \operatorname{Dr}(\mathrm{a}) . \quad$ Conceito

$\operatorname{Prof}(a) . \operatorname{Dr}(a) . \quad$ Conceito

Agosto, 2019 


\section{ACKNOWLEDGMENT}

This project relied on the work of more than 50 hands. A group of people, interested in science and beaches, dedicated a fraction of their time to registering and documenting the beaches with united valves of $T$. mactroides. Thus, their contributions should be acknowledged and valued, and l'd like to thank each one of them for their work.

I must thank everyone that has stopped to listen to my interview pitch, and specially those who accepted to participate. Being interviewed, particularly by a stranger, is an uncomfortable situation for most people, and I cannot appreciate enough those who answered my questions.

I want to thank my parents, for all they always have done for me, for their love and care. I want to thank my advisor, Alexander Turra, for his guidance, mentorship and help. I would like to thank Marcia Denadai, for her advice, knowledge and help, particularly for the field trips.

I want to thank Gabriel, who made the field trips possible. Without his friendship, driving skills and pacience, this work could not exist.

I would like to thank Profo Simone and Nathan of MZUSP for the research support. Also, I have to thank Wagner, as this work would be more poorly researched and written if wasn't for him.

Then, I thank everyone in the Ubatuba Base and CEBIMAR, who helped me in my field work.

Luciana and Mariana: Thank you for saving my academic life several times.

Next, I want to thank all my great friends at Lab. Manejo. lara, Marilia, Marina, Natália, Juliana and Maila, not only for reviewing and helping me with my work, but for being so lovely, and for putting up with me. Each one of you has helped me in ways I cannot put in words.

Finally, I want to thank Hugo, Laura, Hevelim, Amanda, Justin, Dessa, Júlia, Rubens, Gi, Lucas and Dai, because you are my friends.

"This study was financed in part by the Coordenação de Aperfeiçoamento de Pessoal de Nível Superior - Brasil (CAPES) - Finance Code 001" 


\section{LIST OF FIGURES}

Figure 1: Top left (1): External view of a left valve of Tivela mactroides. Bottom left (2): Internal view of a left valve of T. mactroides. Right (3): T. mactroides for sale at $25 \mathrm{de}$ Março Street, São Paulo, Brasil. (Photo: Marcia Denadai).

Figure 2: Flowchart illustrating the strategy employed to overcome the data deficiency of the trigonal clam Tivela mactroides to support the discussion of its inclusion in the List of Endangered Species, The methods are organized in the three objectives of the present study (assess the geographic distribution and trends in size of populations and threats) and three overall methodological approaches (assessment of existing data, exploratory modeling and additional evidences and validation). The numbers on boxes indicate the order of each step within each objective.

Figure 3: Two valves of Tivela mactroides still joined by ligament, interior side facing up - Barequeçaba Beach - São Sebastião. The ligament indicates recent death (Photo: Thaís Rech)...

Figure 4: Number of new records/evidence of occurrence of Tivela mactroides added by each method (steps 1-7). SHS modelling is not represented (step 3). From bottom to top, all the locations that had not been indicated by the method before were counted and plotted.

Figure 5: Locations where Tivela mactroides was recorded or has evidence of its presence in the Northern Coast of São Paulo state. The sources that lead to the record or evidence are represented by icons. The past temporal trends in the size of populations, as perceived by interviewees (experts and community), are also shown. The beaches are marked by a color dot, indicating its Simplified Habitat Suitability rank.

Figure 6: Number of beaches with records of Tivela mactroides in databases and collections divided by municipality.

Figure 7: Number of adequate submissions of pictures of Tivela mactroides from citizen scientists, grouped by beach. The "Grande" beach is in São Sebastião.

Figure 8: The percentage of beaches with and without records (literature review, data repositories and museums, interviews with experts and community and citizen science) of Tivela mactroides by Simplified Habitat Suitability class, considering only records and evidence from or after 1998. Shell observation is shown separately, since it was only performed in beaches with a SHS rank above 5 .

Figure 9: The differences in perceived threats by the experts that talked about threats in terms of the whole coast (light gray) and the experts that specified threats by beach (dark gray). An experts may have answered the questions considering both specific beaches and the whole coast. The threats are shown in terms of times they were mentioned.

Figure 10: The differences in perceived threats by the community members that talked about threats in terms of the whole coast (light gray) and the members that specified threats by beach (dark gray). Community may have answered the questions considering both specific beaches and the whole coast. The threats are shown in terms of times they were mentioned.

Figure 11: Threats to Tivela mactroides in the Northern Coast of São Paulo state described by community and experts, grouped by beach. In parenthesis, the number of people that have mentioned the threat..... 
Figure 12: Future tendencies of the threats to Tivela mactroides, as perceived by interviewees (experts and community), and the time-frame within T. mactroides is expected to be locally extinct, by beach and the perceived extinction horizon. The arrows indicate if the threat is expected to become more intense, less intense or stable in the future.

Figure 13: Interaction with one follower on Facebook, showing that the participant started to pay more attention at beach fauna.

Figure 14: Graph showing: (square) the number of beaches with registers/evidence of Tivela mactroides by Simplified Habitat Suitability (SHS) rank; (triangle) number of beaches where T. mactroides might occur but no records/evidence were found; (circle) the number of beaches in that SHS rank. 


\section{LIST OF TABLES}

Table 1: Short definitions of the concepts in which the criteria for the Red Lists are based. Adapted from International Union for Conservation of Nature (2000).

Table 2: Results of Simplified Habitat Suitability (only scores $>5$ shown), displaying the values for Grain Size (fine sand:3; medium, very fine:2; coarse:1), Slope (lower than $5^{\circ}$ : 3; higher than $5^{\circ}$ and lower than $15^{\circ}: 2$, higher than $15^{\circ}: 1$ ) and Exposure (Exposed:1; Sheltered: 0 ), based on MAREM. The municipality is also indicated for clarity.

Table 3: Interactions with citizen scientists through the project's social media (Facebook, Instagram and Whataspp) pages. Adequate submissions are the ones that follow the guidelines, total submissions are all picture submissions, and other clues are written indications of where Tivela mactroides might be found

Table 4: Threats found in Literature review: to T. mactroides in the Northern Coast of São Paulo State, to T. mactroides in general and to beach clams, as described by Defeo, et al. (2008).

Table 5: List of possible threats to Tivela mactroides mentioned for the Northern Coast of São Paulo and their description. The number of interviewees citing each threat, the number of beaches and number of citations for the entire coast is shown by experts $(E)$ and community (C). The percentages shown in parenthesis, in the case $N^{\circ}$ of interviewees citing this threat and in the $N^{\circ}$ of citations of this threat for the whole coast are in relation to the total number of interviewees, and in the $N^{\circ}$ of beaches for which this threat was cited are in relation to the number of beaches these groups mentioned.

Table 6: Comparison of the perceived advantages and disadvantages of the methods employed for assessing the locations with T. mactroides in the Northern Coast of São Paulo......

Table 7: Comparison of the perceived advantages and disadvantages of the methods employed for assessing the temporal population and the threats to trends T. mactroides in the Northern Coast of São Paulo. 


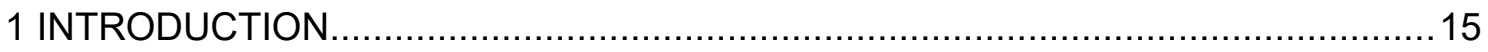

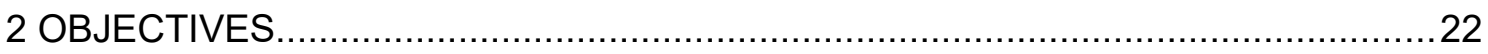

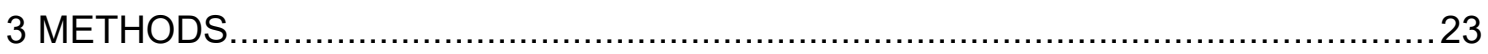

3.1 Assess the geographic distribution of Tivela mactroides in the Northern Coast of

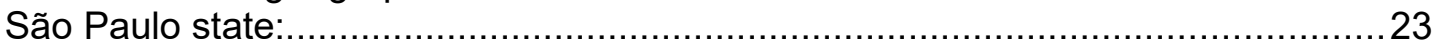

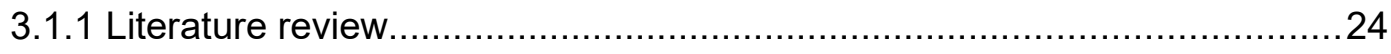

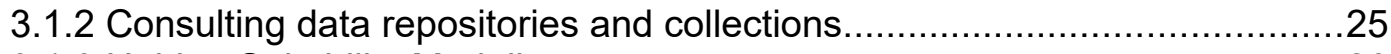

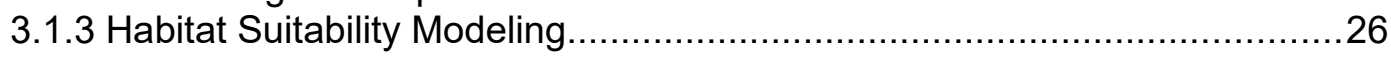

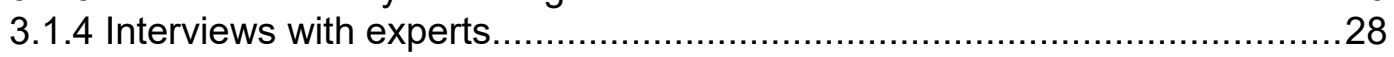

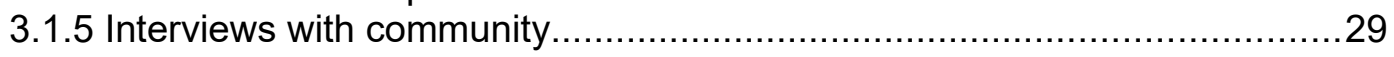

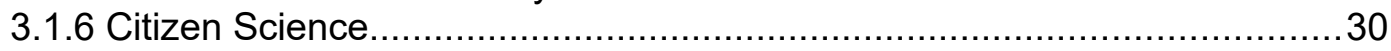

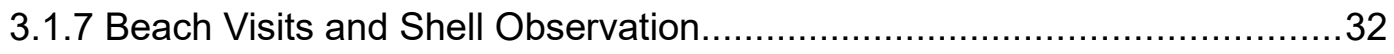

3.2 Assess temporal trends in the size of populations (abundance) of Tivela mactroides on the Northern Coast of São Paulo state...........................................33

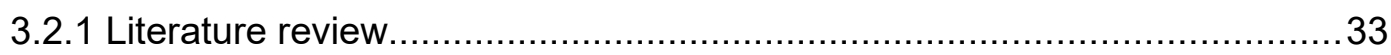

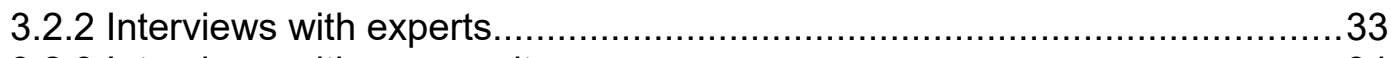

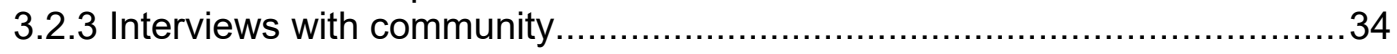

3.3 Identify possible threats to clam populations on the Northern Coast of São Paulo

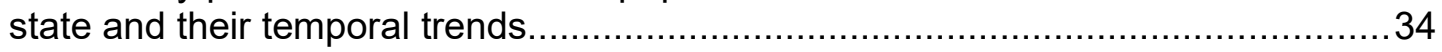

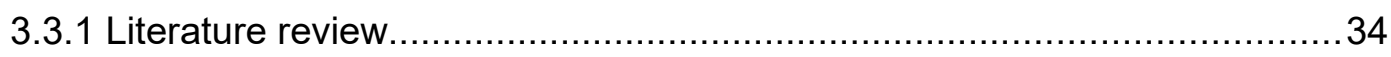

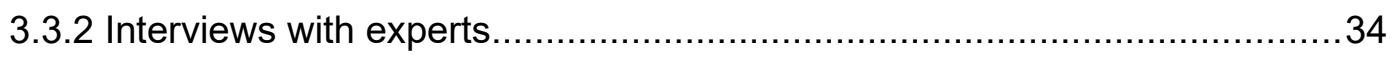

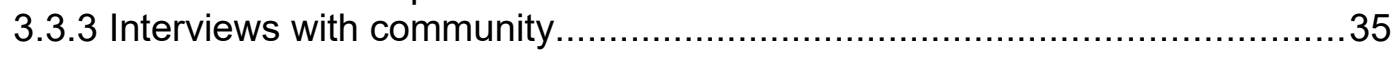

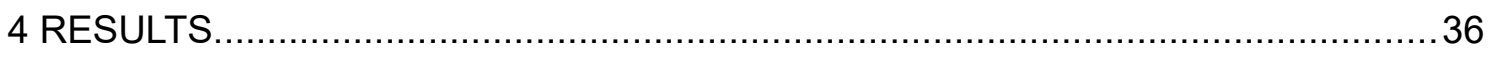

4.1 Geographic distribution of Tivela mactroides in the Northern Coast of São Paulo

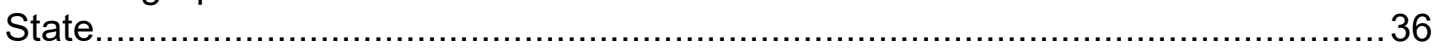

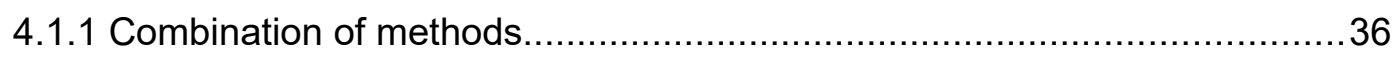

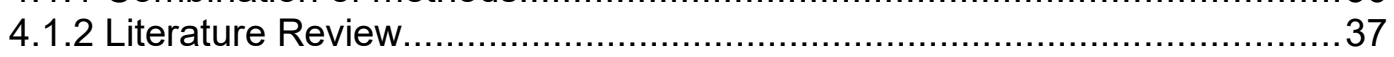

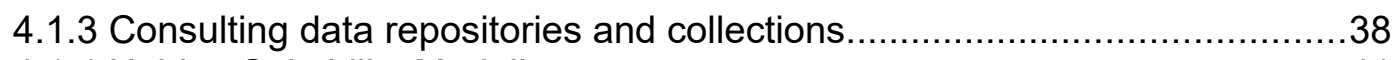

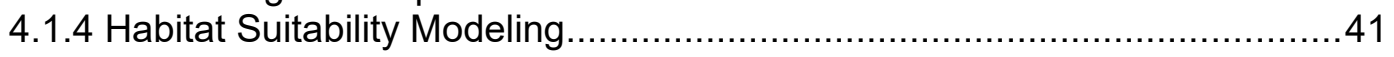

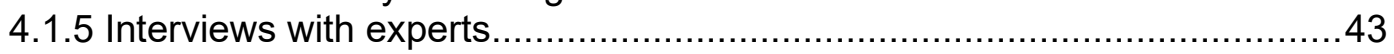

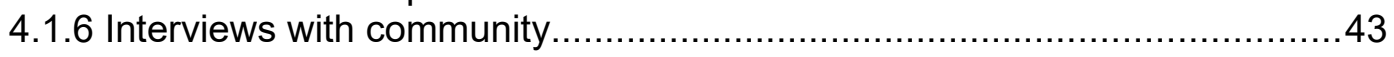

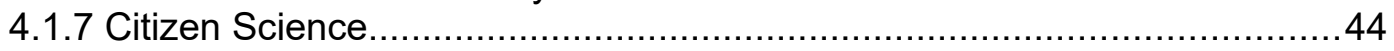

4.1.8 Beach Visits and Shell Observation................................................... 45

4.2 Temporal trends in the size of populations (abundance) of Tivela mactroides on

the Northern Coast of São Paulo state................................................................46

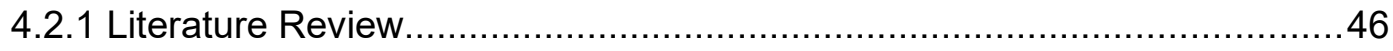

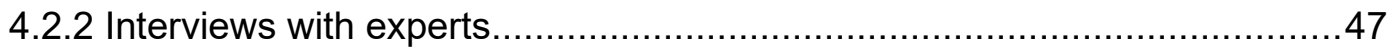

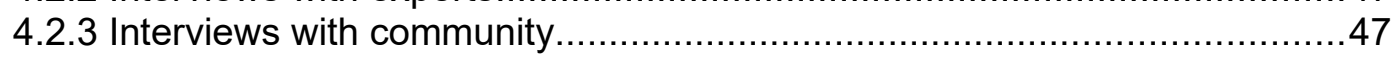

4.3 Possible threats to clam populations on the Northern Coast of São Paulo........48

4.3.1 Literature Review................................................................ 48

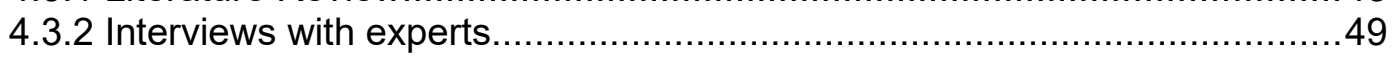

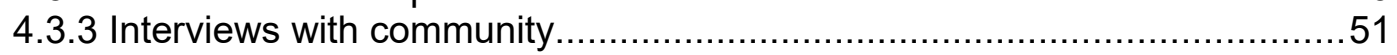

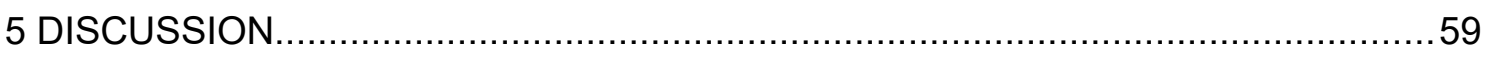

5.1 Application of the stepped approach in Geographic distribution for red list management. 
5.2 Geographic distribution of Tivela mactroides in the Northern Coast of São Paulo

5.3 Application of the stepped approach in the temporal trends in the size of populations (abundance) in applications for other species.

5.4 Temporal trends in the size of populations (abundance) of Tivela mactroides on the Northern Coast of São Paulo state.

5.5 Application of the stepped approach for possible threats to populations in general and applications for other species

5.6 Possible threats to clam populations on the Northern Coast of São Paulo state70

5.7 Tivela mactroides in the List of Endangered Species of the State of São Paulo and applications for other species.................................................................... 75

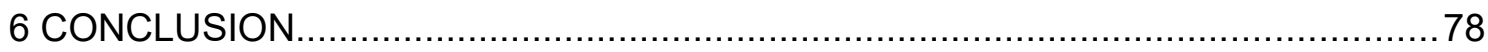

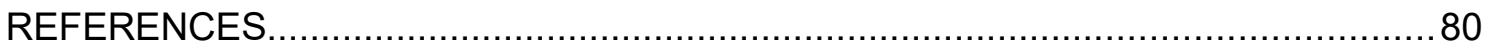

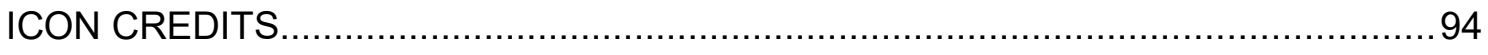

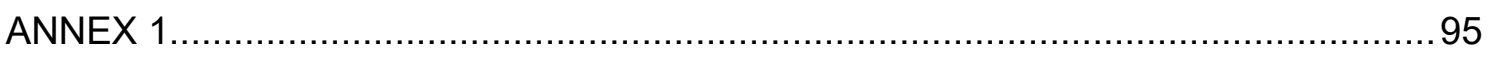

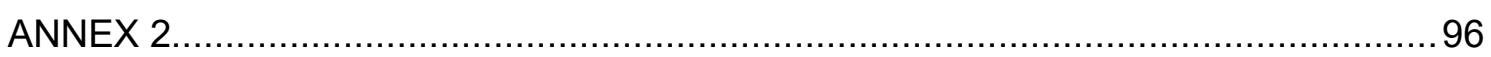

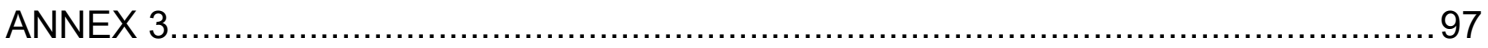

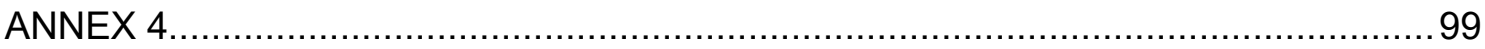

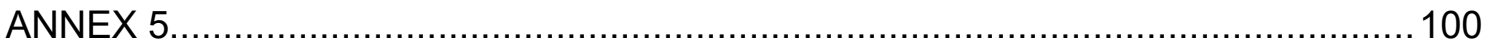

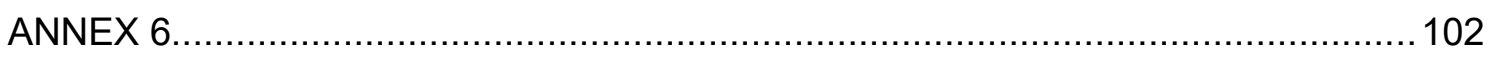

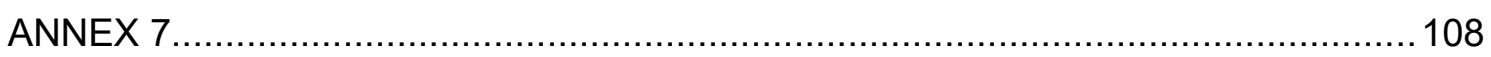

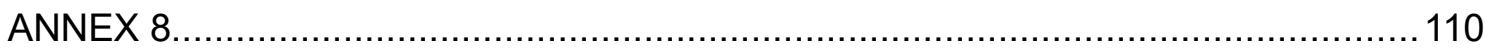

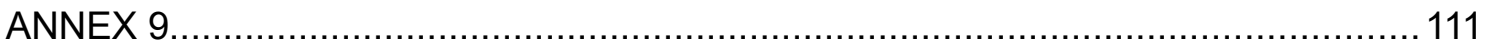

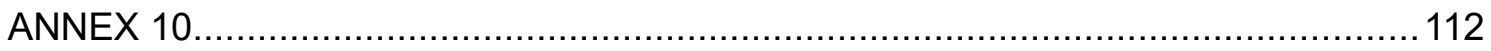

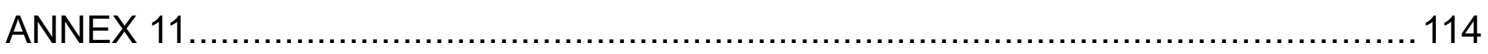




\section{ABSTRACT}

Endangered species lists (or Red Lists) are useful tools for species conservation but, if inappropriately applied, they can be sources of conflict. This situation is aggravated for marine species, whose data deficiency is associated with the difficulties in the acquisition of information about the ecology of most organisms, especially invertebrates. In addition, lists can be made for different administrative levels (Global, National, Regional etc.) and, therefore, adequate information is needed for each of these scales. The list of endangered species of the State of São Paulo, Brazil, includes the trigonal clam Tivela mactroides, a beach bivalve used as food and recreation resource by inhabitants and tourists on the Northern Coast of the state. The lack of information on concepts and criteria to support inclusion in the state Red List and the potential negative consequences of this management tool to clam users raised concern on its application to T. mactroides. To overcome this data deficiency, we employed a stepped strategy to qualify information on its geographic distribution and trends in population size and potential threats. In this work, we developed a strategy of gathering information aiming to improve the categorization of this clam in the list of endangered species. We combined incremental steps considering review of literature and data repositories, simplified habitat suitability model, interviews with experts and local community, citizen science approach and beach validation visits. The combination of the employed methods revealed the occurrence of $T$. mactroides in 59 beaches, more than what could had been previously identified by traditional methods available (41 beaches) to the creation of Red Lists: Literature review, data repositories and experts. The literature was insufficient to inform the trends in population density and the possible threats. The overall temporal trends in the size of populations derived from interviews indicated a decrease, both for specific beaches and for the coastal as a whole. Waste water, oil spills and other pollutants were frequently mentioned, by both experts and communities, while clam capture was not cited as often as a threat. Considering that a species included in the List of Threatened Species of the State of São Paulo is protected from capture by law, the inclusion on the list might not offer full protection for $T$. mactroides due to the existence of multiple threats and the risk of habitat loss. An Ecosystem Based approach, facing both direct and indirect pressures on clam populations, would be the most adequate course of action to support conservation and sustainable use of Tivela mactroides. We demonstrated possible weaknesses and strengths of the methods, proposing that each method can be applied for conservation purposes depending on the characteristics of the project.

Keywords: Marine conservation; Coastal Threats; Citizen participation; Data gaps; Biodiversity loss. 
Listas de espécies ameaçadas de extinção (ou Listas Vermelhas) são ferramentas úteis para a conservação de espécies, mas podem ser fontes de conflito, se aplicadas inadequadamente. Essa situação é agravada para espécies marinhas, cuja deficiência de dados está associada às dificuldades na aquisição de informações sobre a maioria dos organismos, especialmente invertebrados. Além disso, listas podem ser feitas para diferentes níveis administrativos (Global, Nacional, Regional) e, portanto, informações adequadas são necessárias para cada uma dessas escalas. A Lista de Espécies Ameaçadas de Extinção do Estado de São Paulo, Brasil, inclui o berbigão Tivela mactroides, um bivalve de praia usado como alimento e recreação por habitantes e turistas na Costa Norte do estado. A falta de informações sobre conceitos e critérios para apoiar a inclusão na Lista Vermelha estadual e as possíveis conseqüências negativas dessa ferramenta de gestão para os usuários do berbigão aumentaram a preocupação com sua aplicação ao T. mactroides. Para superar essa deficiência de dados, empregamos uma estratégia escalonada para qualificar informações sobre sua distribuição geográfica e tendências no tamanho da população e ameaças potenciais. Neste trabalho, desenvolvemos uma estratégia de coleta de informações visando melhorar a categorização deste bivalve na Lista de Espécies Ameaçadas de Extinção. Combinamos etapas incrementais e inovadoras considerando a revisão de literatura, bases de dados, modelo simplificado de adequação de habitat, entrevistas com especialistas e comunidade, ciência cidadã e visitas de validação de praias. A combinação dos métodos empregados revelou a ocorrência de $T$. mactroides em 59 praias, mais do que poderia ter sido previamente identificado pelos métodos tradicionais (41 praias) disponíveis para a criação de Listas Vermelhas: Revisão de literatura, repositórios de dados e especialistas. A literatura foi insuficiente para informar as tendências da densidade populacional e as possíveis ameaças. As tendências temporais globais no tamanho das populações oriundas de entrevistas indicaram uma diminuição, tanto para praias específicas quanto para o litoral como um todo. Águas servidas, derrames de óleo e outros poluentes foram frequentemente mencionados, tanto por especialistas como por comunidades, enquanto a captura de moluscos não foi citada com tanta frequência. Dado que a espécie incluída na Lista de Espécies Ameaçadas do Estado de São Paulo está protegida de captura por lei, sua inclusão pode não oferecer proteção total para $T$. mactroides devido à existência de múltiplas ameaças e ao risco de perda. Uma abordagem baseada em ecossistemas, enfrentando pressões diretas e indiretas sobre as populações de amêijoas, seria o curso de ação mais adequado para apoiar a conservação e o uso sustentável de T. mactroides. Demonstramos possíveis pontos fracos e fortes dos métodos, propondo que cada método possa ser aplicado para fins de conservação, dependendo das características do projeto.

Palavra-chave: Conservação Marinha; Ameaças Costeiras; Participação cidadã; Lacuna de dados; Perda de biodiversidade. 


\section{INTRODUCTION}

The increase in human population and its demand for resources since the Industrial Revolution, has caused environmental destruction and species extinction. And while continued industrialization polluted environments, larger demand for food has led to the transformation of large extensions of land (SHUKLA et al., 1989). Human nourishment has pressed heavily the fishing stocks, and it is estimated that $31.7 \%$ of all stocks are under unsustainable levels of exploitation (FOOD AND AGRICULTURE ORGANIZATION, 2016). As Halpern et al. (2008) argued, no area in the ocean is unaffected by human drivers.

As a response, humanity has tried to control and limit the negative impacts of its actions, shifting the perspective toward said impacts. In the second half of the last century, several agreements and policies were implemented to conserve and protect the environment. A set of principles came with this perspective shift, should govern decision-taking and environmental law, as exemplified by the Precautionary Principle, thus described by the Rio Declaration:

Where there are threats of serious or irreversible damage, lack of full scientific certainty shall not be used as a reason for postponing cost-effective measures to prevent environmental degradation (UNITED NATIONS CONFERENCE ON ENVIRONMENT AND DEVELOPMENT, 1992).

The application of this principle requires tracing strategies that can be used to support conservation and acting towards a better environment (INTERNATIONAL UNION FOR CONSERVATION OF NATURE, 2007). Since there is a myriad of threats, there are several different tools to be used, each according to the particular circumstances in stake. These actions can have varying emphasis, focusing on ecosystems and areas (i.e. Marine Protected Areas) or on the organisms themselves, as the Lists of Endangered Species or Red Lists (TURRA, in press).

One of the tools aimed at biodiversity protection is the creation of Red Lists, which are compilations that include species whose populations need special attention. This type of list is considered a useful tool in conservation (RODRIGUES et al., 2006), and intends to protect a given set of species and, indirectly, the environment in which they occur, with no special objective of favoring the sustainable exploitation, or even the maintenance of economic and cultural activities (INTERNATIONAL UNION FOR CONSERVATION OF NATURE, 2000). Generally, the lists follow orientation established by the International Union for Conservation of Nature (IUCN), described in 
the IUCN Red List Categories and Criteria (INTERNATIONAL UNION FOR CONSERVATION OF NATURE, 2000).

The Red List consists of a listing of species organized into categories, according to the level and urgency of the threats faced (INTERNATIONAL UNION FOR CONSERVATION OF NATURE, 2000). The IUCN Red List categories for regional and national levels are (INTERNATIONAL UNION FOR CONSERVATION OF NATURE, 2012): Extinct, Extinct in Nature, Regionally Extinct, Critically Endangered, Endangered, Vulnerable, Near Threatened, and Least Concern. In addition to these categories, there is also the Insufficient Data category, which indicates that existing data on the species is not sufficient to determine a conservation status. Three of these categories pose as "threatened": Critically Endangered, Endangered, and Vulnerable.

This classification considers five overall criteria (see below) that establish minimum conditions for framing a given species within a category. Thus, for a species to be classified into any of the Red List categories above, it should fulfill the conditions of one of the following criteria. In a simplified way, the criteria are as follows:

A. Reduction of population size, whether already occurring or foreseen for the near future;

B. Geographical range limited or in extent of occurrence or area of occupation, accompanied by fragmentation, decline or fluctuations in population/geographic reach;

C. Restriction in the number of mature individuals, accompanied by decline, concentrations in the population structure, or fluctuations in the number of mature individuals;

D. Very small or restricted population in the number of individuals/area of occupation;

E. Likelihood of extinction within a certain future period.

These criteria are based on twelve concepts cemented on biological and ecological information (INTERNATIONAL UNION FOR CONSERVATION OF NATURE, 2000) (Table 1).

For populations whose species have distributions that extend beyond the area to which the list refers, there are adjustments that can be applied according to Guidelines for Application of IUCN Red List Criteria at Regional and National Levels (INTERNATIONAL UNION FOR CONSERVATION OF NATURE, 2012). These adjustments seek to consider differences between the evaluation scales (INTERNATIONAL UNION FOR CONSERVATION OF NATURE, 2012). The existence of appropriate information at one level may not be accompanied by appropriate information at another level. 
Table 1: Short definitions of the concepts in which the criteria for the Red Lists are based. Adapted from International Union for Conservation of Nature (2000).

\begin{tabular}{|l|l|}
\hline Concept & Short Definition \\
\hline Population and Population Size & $\begin{array}{l}\text { Population is "the total number of number of } \\
\text { individuals of the taxon", and population size is } \\
\text { measured the "number of mature individuals only". }\end{array}$ \\
\hline Sub-populations & $\begin{array}{l}\text { Geographically distinct groups in the population with } \\
\text { little demographic or genetic exchange between them. }\end{array}$ \\
\hline Mature Individuals & $\begin{array}{l}\text { Number of individuals (known, estimated or inferred) } \\
\text { capable of reproduction. }\end{array}$ \\
\hline Generations & Average age of the parents of the current cohort \\
\hline Reduction & $\begin{array}{l}\text { A decline in the number of mature animals over a set } \\
\text { number of years. }\end{array}$ \\
\hline Continued Decline & $\begin{array}{l}\text { A situation where the decline is projected to "continue } \\
\text { unless remedial measures are taken". }\end{array}$ \\
\hline Extreme Fluctuations & $\begin{array}{l}\text { When population size or area varies widely, rapidly } \\
\text { and frequently. }\end{array}$ \\
\hline Severe Fragmentation & $\begin{array}{l}\text { When most individuals of a population area found in } \\
\text { small and isolated areas, resulting increased risk of } \\
\text { extinction. }\end{array}$ \\
\hline Extension of the Occurrence & $\begin{array}{l}\text { The entire area formed by the polygon created by the } \\
\text { locations with the species }\end{array}$ \\
\hline Area of Occupancy & $\begin{array}{l}\text { "It is a scaled metric that represents the area of } \\
\text { suitable habitat currently occupied by the taxon." }\end{array}$ \\
\hline Location & $\begin{array}{l}\text { A geographically or ecologically distinct area in which } \\
\text { a single event can rapidly affect all the members of } \\
\text { the species. }\end{array}$ \\
\hline Quantitative Analysis & $\begin{array}{l}\text { A form of analysis which estimates extinction } \\
\text { probability of a taxon }\end{array}$ \\
\hline
\end{tabular}

The IUCN categorization guide itself says that the apparent lack of knowledge about a particular species at a given spatial scale should not preclude an honest attempt to categorize the organism (INTERNATIONAL UNION FOR CONSERVATION OF NATURE, 2000), thus exercising the aforementioned Precautionary Principle. This is particularly important in the Southern Hemisphere, (MILOSLAVICH et al., 2011), for marine biota as a whole and for certain taxonomic groups (such as invertebrates), for which available and systematized information is less abundant (CARDOSO et al., 2011). Globally, IUCN assessments are disproportionately focused in well-described groups, which tend to be non-marine, and the proportion of Data Deficient classifications in marine taxa is twice the proportion in non-marine (WEBB; MINDEL, 2015).

In these cases, the use of alternative strategies such as: Species distribution modeling, or Habitat Suitability Models (which is model of habitat adequacy, made from previously existing information) (LAURIA et al., 2015); Expert Survey (which consists in accessing the knowledge of experts in the field) (TOMASINI, 2018); Traditional Ecological Knowledge (TEK) (consisting of accessing the knowledge held by traditional populations) (SHACKEROFF; CAMPBELL, 2007); Citizen Science, or science made by 
non-scientists (in which persons outside academia and research centers are responsible for data collections and/or analysis) (ELLWOOD; CRIMMINS; MILLERRUSHING, 2017; MCKINLEY et al., 2017); non-systematic methods of data collection, or "opportunistic data" (data collected in a non-systematic way) (MAES et al., 2015); and proxies, or indirect indicators (researching one subject to represent another) (CASALE; TUCKER, 2015) may be valuable.

There have been studies addressing the lack of appropriate info for conservation decision-making, applying each of the methods described above individually, and studies focusing in the creation of Red Lists. In doing so, these works use the IUCN guidelines for the application of the Precautionary Principle, especially Guideline 5 - Use the Best Possible Information, and Guideline 6 - Characterize Uncertain Threats (INTERNATIONAL UNION FOR CONSERVATION OF NATURE, 2007). However, studies combining multiple alternative approaches to offer a framework for tackling the lack of appropriate information for a Red List are at least uncommon. In the present study, we investigated the potential of an incremental data gathering to overcome the data insufficiency in the case of Tivela mactroides (Born, 1778), a trigonal clam present in the sandy beaches of São Paulo state, seeking to obtain information that inform the IUCN concepts.

The present work aimed to overcome the data limitation by proposing, applying and discussing a stepped strategy to qualify information for the application of Red Lists to data deficient species. We conducted a case study on the potentially inappropriate categorization of the trigonal clam T. mactroides in the List of Endangered Species of the State of São Paulo, southeastern Brazil. In the State of São Paulo, the application of the Red List is reflected in the List of Endangered Species of the State of São Paulo, as promulgated in State Decree $N^{\circ} 63,853 / 2018$. The species was first included in the list in the previous State Decree $N^{\circ} 60,133 / 2014$, which is the base for this study. Despite the indication that IUCN guidelines should be followed, the 2014 decree did not indicate in which IUCN category the listed species might fit, nor did it provide justification for most species framed as endangered.

The trigonal clam T. mactroides (Figure 1) is among the species listed in the List of Endangered Species of the State of São Paulo, in 2014 and 2018. This animal, also known as berbigão, vôngole or sapinhauá, is a bivalve mollusk with socioeconomic (TURRA et al., 2016) and ecological (TURRA et al., 2015) importance in the Northern Coast of the State of São Paulo. T. mactroides can be found on moderately exposed and dissipative beaches (MCLACHLAN, 1996; MCLACHLAN et al., 1996), in the intertidal region up to depths of $5 \mathrm{~m}$. It is found in heterogeneous sediments, from coarse sand to mud (AMARAL; RIZZO; ARRUDA, 2005). This species occurs from 
Venezuela and parts of the Caribbean (RIOS, 1985; MCLACHLAN, 1996) to Brazil, where it is found from the Northeastern Coast to Santa Catarina state (Balneário Camboriú) (MCLACHLAN et al., 1996; MEDEIROS; HENRY-SILVA, 2014) and throughout the coast of the state of São Paulo.

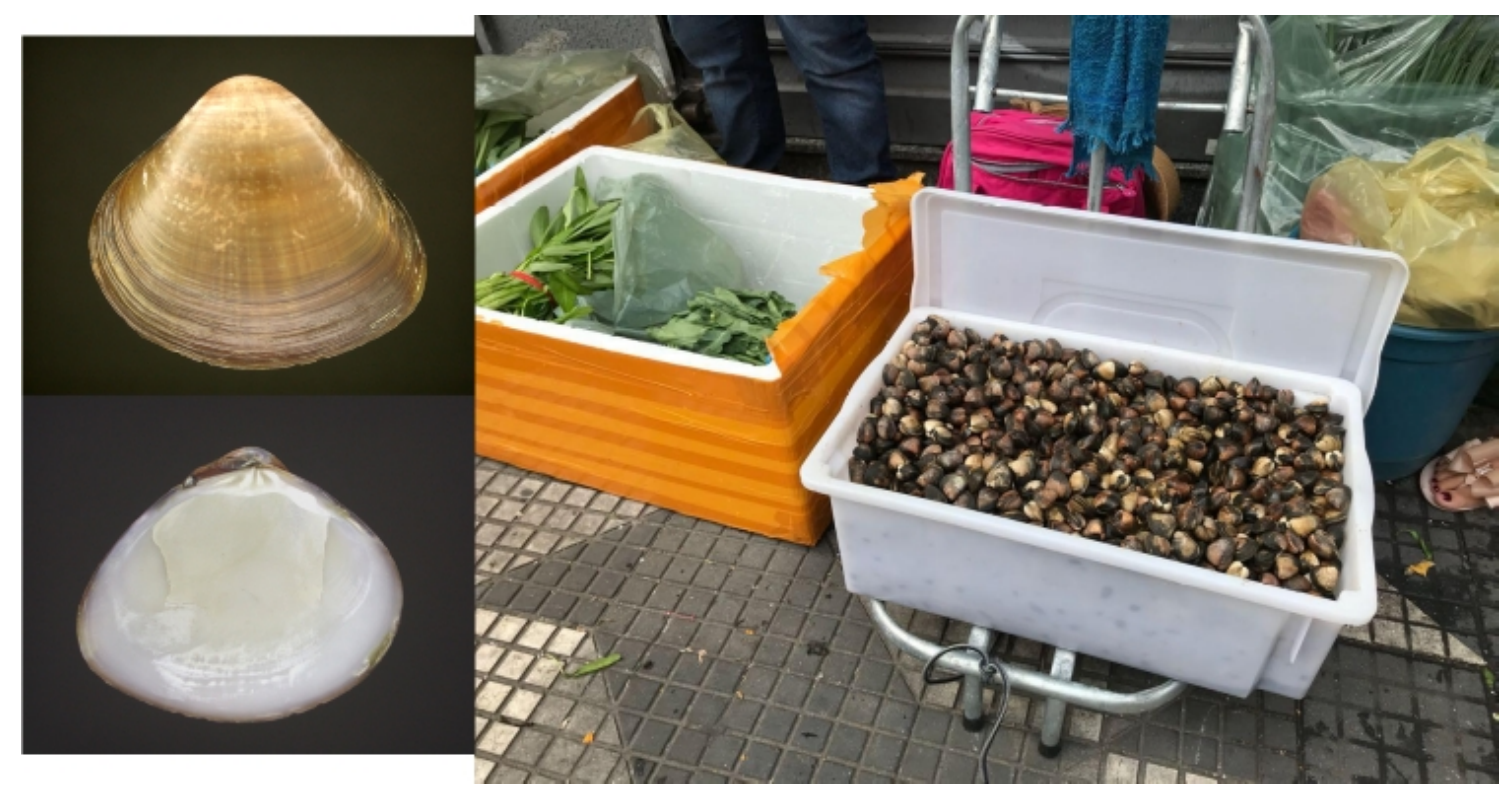

Figure 1: Top left (1): External view of a left valve of Tivela mactroides. Bottom left (2): Internal view of a left valve of T. mactroides. Right (3): T. mactroides for sale at 25 de Março Street, São Paulo, Brasil. (Photo: Marcia Denadai)

T. mactroides is extracted by both tourists and residents (Figure 1, right; the situation represented in the picture is not so common) (TURRA et al., 2014) and, according to Turra et al. (2016), about 30 tons are collected in the beaches of Caraguatatuba Bay yearly. In fact, T. mactroides is considered a fishery, as defined by Article $36^{\text {th }}$ of Federal Law 9,605/1998, and its capture must be authorized in accordance with Article $6^{\text {th }}$ of Decree $N^{\circ} 60,133 / 2014$. If fishing is authorized, a fee for its commercial practice must be paid, and the Article $1^{\text {st }}$, item III of Law $N^{\circ} 11,959 / 2009$ prescribes punishment for those who fish without a license. The first paragraph of Article $3^{\text {rd }}$ of Decree $N^{\circ} 8,425 / 2015$, which regulates the Articles 24 and 25 of Law $11,959 / 2009$, establishes that "fishermen and subsistence fishermen who engage in fishing for purposes of domestic consumption or barter" (e.g. episodic capture by tourists) are exempt from the license or authorization to carry out the activity. Amateur fishermen would be required to obtain a license, as described in Article $2^{\text {nd }}$ of the same law, and to the determinations of the Inter-ministry Normative Instruction of the Ministry of Fisheries and Aquaculture/Ministry of Environment (MMA) N $N^{\circ}$ 9/2012. The inclusion of $T$. mactroides in the List of Endangered Species of the State of São Paulo, as described above, overrules these regulations, forbidding all capture of the species. 
Although there is evidence that the capture of $T$. mactroides could lead to a decrease in the local population, as seen in Venezuela (ARRIECHE; PRIETO, 2006), the trigonal clam faces other threats than extraction. Beach nourishment may have decimated the population of $T$. mactroides for a section of the coast in Balneário Camboriú (Santa Catarina state, Brazil), where the mollusks were apparently smothered by the added sand and by the change in grain composition (PEZZUTO et al., 2006). T. mactroides is also subject to density-dependent mass mortality events, ending up "stranded" out of the sand; this risk being higher in situations under higher hydrodynamic conditions (TURRA et al., 2016b). There is also evidence that the use of beaches by humans (e.g. trampling by tourists) can affect the abundance of some invertebrates (SCHLACHER; THOMPSON, 2012), including bivalves. Moreover, mean sea level rise (MSLR), which is expected to increase by up to 80 centimeters by 2100 , can completely modify the coastal environment that $T$. mactroides inhabits (MAGRIN et al., 2014).

Considering that the direct capture may not the most relevant driver of $T$. mactroides population decline, its inclusion in the Red List may be controversial, since this decision has a potential to cause socioeconomic impacts in the local human population that traditionally exploits it. A similar situation, with social conflicts and loss of cultural capital, has happened with the mangrove crab (Ucides cordatus) (SÃO PAULO, 2015), which was added into the List of Threatened Species of the State of São Paulo, effectively prohibiting its economic and subsistence extraction, cutting hundreds of people off their means of subsistence (SÃO PAULO, 2015). Given its extraction and the importance of tourism to the Northern Coast of the state of São Paulo, management measures to protect $T$. mactroides are needed.

To avoid such conflicts, the elaboration of Red Lists should benefit from the best available knowledge. However, especially in data deficient species as Tivela mactroides, the available information may not be enough to support decision-making regarding the IUCN criteria needed to categorize species in the Red List. In such cases, strategies that qualify the information for the application of the Red Lists are needed. Moreover, the potential socioeconomic conflicts generated by this conservation tool may call for a kind of "Social Precautionary Principle" as well as other conservation strategies, including the ecosystem-based approach (TURRA et al., 2017). In other words, conservation of this beach clam may be secured by combating the direct and indirect threats that affect its geographic distribution and population density. This is specially relevant when facing a fragmented environment with different populations (or sub-population) not directly connected. This is the case of $T$. mactroides in the Northern Coast of São Paulo. 
The Northern Coast of São Paulo has a very jagged coastline, oriented roughly northeast-southwest, with reflective, dissipative beaches interspersed by rocky shores (SOUZA, (1997); TESSLER et al., 2006). Four municipalities are part of this region (from north to south): Ubatuba, Caraguatatuba, São Sebastião and Ilhabela, with an estimated population of 319,511 in total (INSTITUTO BRASILEIRO DE GEOGRAFIA E ESTATÍSTICA, 2016) and tourism being a very important economic activity (SÃO PAULO, 2014b). The inherent fragmentation of the beach habitat and the asymmetric occupation of the coast faces $T$. mactroides to different threats along the coast, situation that will also be part of the present study. 


\section{OBJECTIVES}

The main objective of this work is to propose and discuss a strategy to qualify information for the application of the Red List. We targeted data gaps (i.e. where scientific knowledge was not broadly available) on Tivela mactroides in the Northern Coast of São Paulo state and proposed a stepped strategy to overcome them. We intended to analyze the pros and cons of the proposed strategy as well as its potential to be transferred to other species and locations.

We focused on an adaptation of the IUCN concepts and criteria mentioned before related to the geographic distribution of $T$. mactroides and trends in population size and threats. Of the five criteria used by IUCN, it was decided to investigate the information need for criterion $A$ (reduction in population size), $B$ (geographical range) and $E$ (likelihood of extinction), as they are particularly important in the current situation of Tivela mactroides in the Northern Coast of São Paulo. Consequently, these criteria were related to the following concepts of Population, Reduction, Continued Decline and Location linked to T. mactroides in the Northern Coast of São Paulo. The specific objectives presented below are thus complementary, in which the first ones may support (and be complemented by) the remaining. A specific strategy was proposed for each of these objectives, considering methods planned to be undertaken in a progressive approach, as explained below:

1. Assess the geographic distribution of T. mactroides in the Northern Coast of São Paulo state:

2. Assess temporal trends in the size of populations (abundance) of $T$. mactroides on the Northern Coast of São Paulo state.

3. Identify possible threats to clam populations on the Northern Coast of São Paulo state and their temporal trends.

Each objective is related to a set of concepts, Objective 1 is more closely linked to Location and Area of Occurrence, while Objective 2 is related to Reduction and Objective 3, to Quantitative Analysis and Extinction. Concepts relating to sexual maturity, such as Mature individuals and Generation are particularly relevant to species that may have impediments to reaching reproduction age, affecting directly criterion $\mathrm{C}$. $T$. mactroides should not be much as dependent to these concepts, as it is a species with relatively short life cycle (DENADAI et al., 2015b). Moreover, evaluating sexual maturity would require laboratory studies, which oppose the intent of creating a simpler framework. As a compromise, it was decided to focus on the exposed part of the beach, as the clam usually occupies the face of the beach (intertidal) in its adult phase, completing its life cycle (DENADAl; AMARAL; TURRA, 2005). 


\section{METHODS}

This work consisted of a series of complementary steps, each of them adding a new level of understanding to the selected concepts and criteria needed for a Red List evaluation related to geographic distribution (Objective 1) and trends in size of populations (Objective 2) and threats (Objective 3). For each of these three objectives, there was a set of methods that were taken in order to move from more consistent sources of scientific information (e.g. scientific papers, data repositories and museum records) to other complementary and potentially less robust but still informative data. In the absence of available scientific information, and given the difficulties to estimate the total population size and the distribution of Tivela mactroides in the Northern Coast of São Paulo state by direct sampling, indirect and alternative methods were proposed and implemented, some of them applied in the three objectives (Figure 2).

The initial steps consisted of identification of existing data based on literature review and consultation of data repositories and museums collections, which are wellestablished and traditional approaches employed for Red List creation (TOMASINI, 2018). As the steps progressed, the approaches became more exploratory, including modeling techniques (Habitat Suitability Model) (LAURIA, 2015), and complementary, including principles and methods related to etno-ecology (i.e. Traditional Ecological Knowledge) (TOLEDO; BARRERA-BASSOLS, 2009) and post-normal science (i.e. expert consultation and citizen science) (FUNTOWICZ; RAVETZ, 1993). To compensate the potential bias of these methods "opportunistic data" (i.e. shell sighting at the beach) (ISAAC; POCOCK, 2015), some overlap among the different methods was sought. Below, the different methods used in each objective are described.

3.1 Assess the geographic distribution of Tivela mactroides in the Northern Coast of São Paulo state:

To assess the geographic distribution of Tivela mactroides seven steps were proposed and employed. The assessment of existing data recalled on (1) literature review and (2) consultation of data repositories and collections. Such data allowed an exploratory estimation of the potential distribution through a simplified Habitat Suitability Modeling (3). Additional evidences of occurrence were gathered from interviews with (4) experts, (5) interviews with community, (6) a citizen science approach and (7) shell observation in beaches. The citizen science and shell observation methods were also used to validate some of the information produced by 
previous methods, using indirect evidence of clam occurrence at the beach (recently dead individuals, see below).

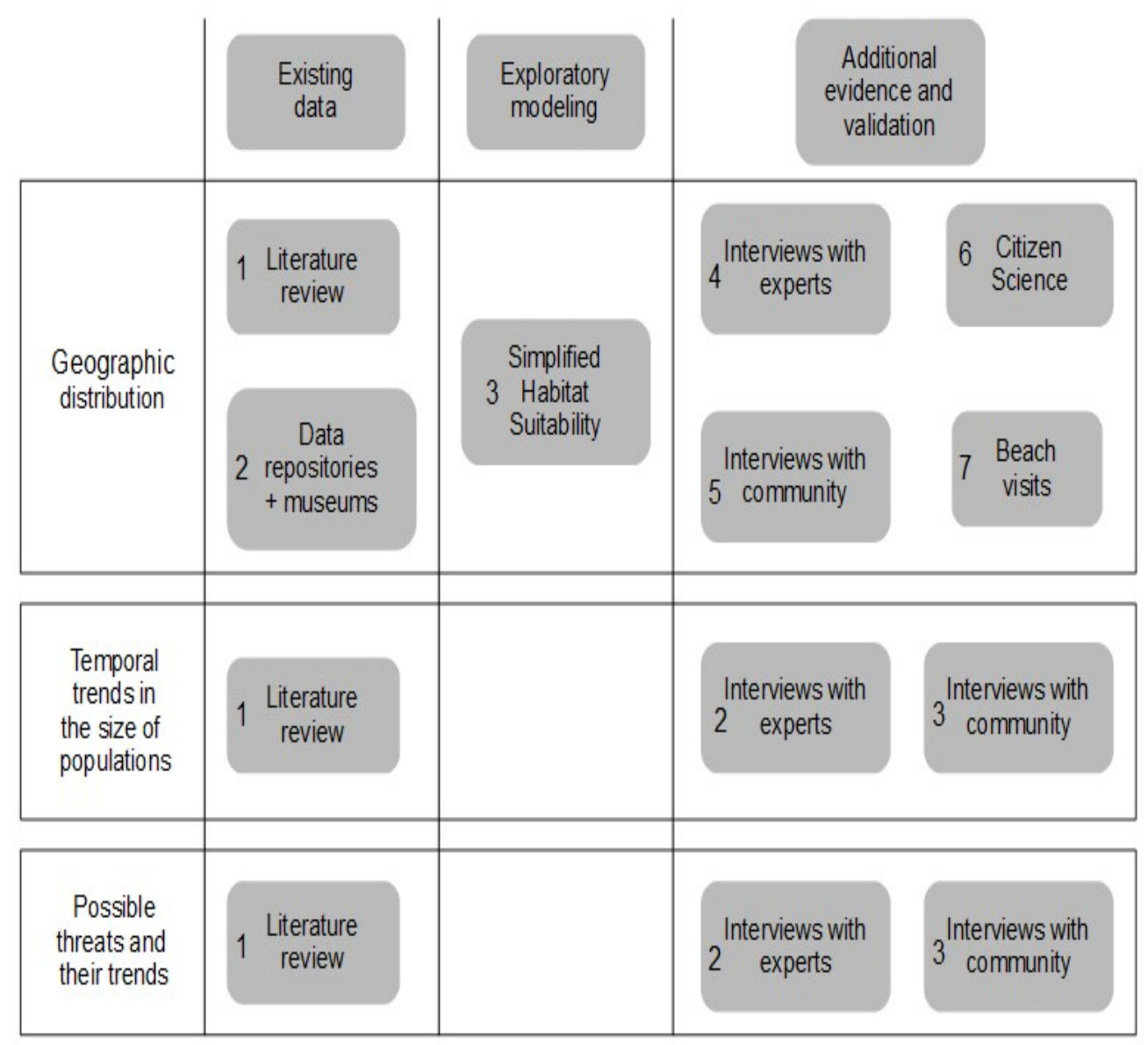

Figure 2: Flowchart illustrating the strategy employed to overcome the data deficiency of the trigonal clam Tivela mactroides to support the discussion of its inclusion in the List of Endangered Species, The methods are organized in the three objectives of the present study (assess the geographic distribution and trends in size of populations and threats) and three overall methodological approaches (assessment of existing data, exploratory modeling and additional evidences and validation). The numbers on boxes indicate the order of each step within each objective.

\subsubsection{Literature review}

Literature review is the procedure in which existing scientific works are surveyed in order to obtain available information and knowledge for the current project. There are several types of literature review, depending on their objectives and rigor of assessment (GRANT; BOOTH, 2009). A careful and in-depth literature review was done to identify the area of occupation and the distribution of Tivela mactroides in the study region. The terms "Trigonal clam", "Northern Coast", "Tivela mactroides", Ubatuba, Caraguatatuba, "São Sebastião", Ilhabela, "São Paulo" were searched, both in portuguese and english, in different combinations in the following search engines: Google Scholar, ScienceDirect, and "Sistema Integrado de Bibliotecas da USP". The 
search was limited to articles published until 2017, as that was the year the search was conducted. A snowball review was then made within the articles, following other studies that looked into the presence of T. mactroides (GRANT; BOOTH, 2009; WNUK; GARREPALLI, 2018).

A time-frame was created to separate older records, which might not guarantee or support the actual occurrence of $T$. mactroides in a given site, and newer ones, as some of the results are very old. Considering the period of twenty years indicated by the criteria for Critically Endangered to represent a "fast" extinction, we established 1998 as cutoff date, assuming that records prior may not be as a reliable indicator of current presence on a given beach.

\subsubsection{Consulting data repositories and collections}

Online databases and data repositories are initiatives that list species records, geographic distributions and occurrence, and can be accessed generally through a website, providing "insight into historical trends of critical importance for conserving resources in an era of global change" (BALKE et al., 2013). They usually contain information sourced from traditional collections, such as museums and universities, researchers' and project's submissions and verified high-quality citizen science projects, like iNaturalist (GLOBAL BIODIVERSITY INFORMATION FACILITY, 2018). They are helpful tools to understand the complete distribution of a species (CARDOSO et al., 2011).

In this step, online databases, data repositories and shell collections (museums, private) were consulted and analyzed. Two databases were employed in this work, speciesLink and the Global Biodiversity Information Facility. SpeciesLink (http://www.splink.org.br) is a "project that aims to integrate the primary information on biodiversity that is available in museums, herbaria and microbiological collections, making it freely available on the Internet" (FUNDAÇÃO DE AMPARO À PESQUISA DO ESTADO DE SÃO PAULO, 2007) that allows the user to look for projects/collections that have located the species, providing the user with geographical and correspondent metadata. The Global Biodiversity Information Facility (GBIF) (https://www.gbif.org/) "is an open-data research infrastructure funded by the world's governments and aimed at providing anyone, anywhere access to data about all types of life on Earth" (GLOBAL BIODIVERSITY INFORMATION FACILITY, 2018), allowing the user to search for geographic location and metadata for the targeted species. They aggregate records from institutions from around the world and other biogeographic databases. 
The online databases used in this work were chosen because they included the study area in their record bases. Furthermore, records from museums and collections were assessed, as to include records from local institutions and collectors that may not have linked their catalogs to the online databases: Natural Sciences Museum of the Zoo-Botany Foundation of Rio Grande do Sul; Museum of Zoology of the University of São Paulo; the private collections of José Tarasconi and Femorale (a company that sells seashells).

The searches were conducted between July and October, 2017. Data which had geographic coordinates was collected and added to the map of the study area. When only the name of the location was available, a point was added on said beach. Other information (dates, collector...), when available, was also recorded. The records were sorted in the same time-frame described in chapter 3.1.1, by whether they were from before or after 1998 .

\subsubsection{Habitat Suitability Modeling}

Habitat suitability is the habitat's potential to support a particular species, which can be modeled from the structural characteristics of the habitat the species is known to occur (U. S. FISH AND WILDLIFE SERVICE, 1980). Habitat suitability models have been used to guide conservation initiatives (MORINHA et al., 2017), among other uses. Through a habitat suitability model (HS), the number of beaches suitable for the occurrence of Tivela mactroides can be inferred.

To create a model, we looked into the structural characteristics of the beaches that host T. mactroides. Works by Amaral, Rizzo and Arruda (2005) and Defeo and Maclachlan (2011) were used to guide which characteristics would be taken into account for HS, restricting the occurrence of the species to sandy shores with grain size between 1 and $6 \varphi$ (fine sediments), gentle slope (here defined as inclination of 15 degrees or fewer) were considered potentially suitable for the organism. Additionally, Turra et al. (2014) described other parameters (coefficient of sediment sorting, wave period, wave height and wave frequency) that are also linked to the presence and abundance of $T$. mactroides, in Caraguatatuba Bay From this information, we reached an initial set of characteristics (particle size, sorting, beach slope, beach exposure, wave period, wave height and wave frequency) that could be used to create the model. However, there is an absence of robust data on the physical characteristics of sandy beaches in the region as well as biological data on $T$. mactroides.

The main source of structural characteristics information to implement the SHS was MAREM (Mapeamento Ambiental para Resposta à Emergência no Mar), a joint 
program of Instituto Brasileiro do Meio Ambiente e dos Recursos Naturais Renováveis (IBAMA) and Instituto Brasileiro de Petróleo, Gás e Biocombustíveis (IBP) that identifies stretches of the São Paulo coast with potential for conservation (INSTITUTO BRASILEIRO DO MEIO AMBIENTE E DOS RECURSOS NATURAIS RENOVÁVEIS, 2018). Since information obtained at MAREM was qualitative and often described in broad terms, sometimes more information was necessary to properly attribute values to the beaches, so the sources on the table in ANNEX 1 were used.

Then a ranking system based on the beach's characteristics was created, attributing discrete values to each characteristic. The more suitable the characteristics, the higher the value assigned. As the characteristics described in the previous paragraph are broad, it was needed to assign the highest value of any indicator to the characteristics similar to those of Caraguatuba Bay, because this beach presents a well-established population of $T$. mactroides, with numerous recent records of occurrence, thus it is considered to have an ideal set of physical characteristics for the species. Based both on the few existing physical information on the beach $T$. mactroides and the quality of the information on the morphodynamics of the beaches in the Northern Coast, we proposed an adaptation of the HS using an additive and discrete approach, with categorical values, which was named Simplified Habitat Suitability (SHS).

To attribute values for grain size, we compared the reported grain size of the places in the Northern Coast to establish values for each grain size class, since literature described a very broad (from coarse sand to mud) gran size as suitable for $T$. mactroides (AMARAL; RIZZO; ARRUDA, 2005). We set fine sand as the ideal grain particle, as per (DENADAl et al., 2015b), attributing the highest value (3) to this grain size. Beaches with grain size classes right above (medium) and right below (very fine; coarse silt) were given a score of two. Coarse sand was assigned the value of 1 , as we found some beaches with this grain size with T. mactroides. Finally, fine silt and clay received a value of zero, as they would be unsuitable for the species.

We followed a similar procedure for slope, with steeper $\left(>15^{\circ}\right)$ beaches scoring 1 , gentle slopping $\left(<5^{\circ}\right)$ ones scoring 3 , and intermediate ones $\left(5^{\circ}\right.$ to $\left.15^{\circ}\right)$ scoring 2. Meanwhile, the system to evaluate exposure was binary, due to the classification employed by MAREM considered only exposed or sheltered conditions. Then, we set score one for exposed beaches and zero for sheltered ones. This information was included in a spreadsheet, the characteristics according to the system described above were evaluated, adding the values given and ranking the result. The highest total possible added rank was seven, meaning the locations most suitable to have a population of the studied species. Beaches with higher total values were the most 
suitable for T. mactroides, as was the case of Caraguatatuba bay which, by definition, received the total value of seven. A beach with an added rank of seven should be very close to an ideal habitat for T. mactroides. Even using the MAREM database, there was no information on the beach characteristics for some locations; we did not assign any value in such cases.

The SHS considered all the beaches in the Northern Coast of São Paulo state, based on the oficial website of the municipalities (PREFEITURA MUNICIPAL DE UBATUBA, 2017; PREFEITURA MUNICIPAL DE CARAGUATATUBA, 2019; PREFEITURA MUNICIPAL DE SÃO SEBASTIÃO, 2019), tourism websites (ILHABELA.COM.BR, 2019; NATURAM, 2019; PRAIAS-360, 2019) and MAREM". From the 201 beaches listed in total, some of them represented only different names for sections of the same geographic feature or beach arc. For the purposes of this work, the different sections were considered as a single beach, shrinking the number of beaches to 191. For examples, all 9 beaches in the Caraguatatuba part of the Caraguatatuba Bay were treated together. Since SHS was considered an exploratory strategy to assess potential additional beaches where T. mactroides could occur, the noise caused by such data gaps can be overcome by the additional methods used. The following steps improve on the simple SHS model, conferring it against other method methods.

\subsubsection{Interviews with experts}

Expert consultation is the method in which the information is obtained from a person with academic/scientific experience with the target species (BLAND et al., 2018). There are other examples of expert consultation in Red List settings; Fourcade (2016) has shown that species range maps created for IUCN Red Lists can be value tools in species distribution modeling, while Graham e Hijmans (2006) have shown that expert-drawn range maps may be good representations of real range.

We conducted semi-structured interviews with experts, in order to identify beaches with occurrence of Tivela mactroides and if the species was recently seen in those locations. We considered experts scientists in Bivalvia and beach ecology on the Northern Coast of São Paulo, that have studied T. mactroides in the region, reaching out researchers with field experience in the Northern Coast, preferably authors of papers about T. mactroides. The interviews with the specialists started out with contacts at University of São Paulo, talking to authors of papers about T. mactroides. To reach other interviewees, we used the "Snowball" method, (WRIGHT; STEIN, 2005) in which each interviewee indicated other people that fulfilled our criteria to be

1 List of beaches collected by lara Ottoni, graduate student at Instituto Oceanográfico - IO 
interviewed, maximizing the information retrieval. Once we contacted the candidates, they self-accessed if they had the knowledge needed to answer all he questions.

The interviews were conducted between December, 2017 and September, 2018. The questionnaire is presented in ANNEX 2. Questions 1 to 4 are related to the Objective 1, pertaining to which locations the interviewee has seen T. mactroides, the year they first saw it in said location, and if T. mactroides is still present. The interviews were duly registered in Plataforma Brasil, for evaluation by the ethics committee. The Free and Enlighted Consent form, a document that asserts that the person being interviewed was thoroughly informed in their decision of participating, was signed by the experts (ANNEX 3).

\subsubsection{Interviews with community}

The use of local knowledge has been widely used in Red Lists, as exemplified by about $50 \%$ of the makers of European Red Lists used local knowledge in their assessments, even if not all of them acknowledged so (TOMASINI, 2018). The use of interviews and consultations takes full advantage of traditional ecological knowledge, different perspectives and experiences, allowing a more plural view on the conservation needs and the use of Tivela mactroides (BOCKSTAEL et al., 2016). A set of interviews with community members of the municipalities of Ubatuba, Caraguatatuba, São Sebastião and Ilhabela was conducted between February and September 2018.

The ideal profile of community interviewee is a person acquainted with the beaches in the study area. To reach them, the interviews were conducted in communities with concentrations of artisanal fishermen. We selected the communities based on the Programa de Ação Participativa para a Pesca (PAPP), from Petrobras (PETROBRÁS, 2007), a program that identified traditional fishing communities in the Northern Coast of São Paulo. After asking local contacts which of the communities were most likely to have persons with experience with clams, the original 22 communities listed were narrowed down to 12: São Sebastião (Barequeçaba, Enseada e São Francisco); Ilhabela (Barra Velha, Portinho e Jabaquara); Caraguatatuba (Camaroeiro, Porto Novo e Tabatinga) e Ubatuba (Saco da Ribeira, Iperoig/Itaguá e Maranduba). The interview effort was initiated at these localities and the snowball method was employed, as indications were given by interviewees. Up to two attempts were made to find the persons referred by interviewees. Once we explained the content of interview, they self-accessed if they believed they had the knowledge needed to answer all the questions. 
The community members were asked to identify beaches with occurrence of $T$. mactroides and if the species was recently seen in those locations. The questionnaire is presented in ANNEX 4. Questions one to seven are related to Objective 1, pertaining to which locations the interviewee has seen $T$. mactroides, the year they first saw it in said location, and if $T$. mactroides is still present. The first and the second questions were used to filter out persons that did not know T. mactroides and to establish a common name to address the species, while the third was used to find out if the person could tell T. mactroides apart from Anomalocardia brasiliana (Gmelin, 1791). This is an important point, as both species can be called "berbigão" and are edible. Answers of persons that treated these two species as the same were not considered to assess the geographic distribution of T. mactroides in the Northern Coast of São Paulo state.

In an additional attempt to complement interviews, finding possible participants and reaching a larger pool of persons, an online-questionnaire (ANNEX 5) was sent via social media and message to networks and groups in the Northern Coast of São Paulo. This questionnaire was used to screen possible participants, who were interviewed in full later. The interviews are not statically representative of any social group, as we intentionally targeted people with a type of knowledge (i.e. observe T. mactroides for a long time). Furthermore, the total number of targeted people (population) cannot be calculated, so a sampling $\mathrm{N}$ could not be estimated.

The interviews were duly registered in Plataforma Brasil, for evaluation by the ethics committee, same as the interviews in chapter 3.1.4. The of Free and Enlighted Consent form, a document that asserts that the person being interviewed was thoroughly informed in the their decision of participating, is on ANNEX 3.

\subsubsection{Citizen Science}

A Citizen Science component was added to strengthen our strategies, hoping to improve our geographic reach. Citizen Science is the science in which the data collection or analysis is made by persons outside academia and research institutions (MEMARSADEGHI, 2012). Citizen science has already been used to obtain information to support the creation of IUCN Red Lists, as in the case of palm trees (GARDINER; BACHMAN, 2016) and saproxylic beetles (ZAPPONI et al., 2017). For the less conspicuous marine fauna, Edgar et al. (2017) focused on two cryptic species in the Australian Reef Barrier, relying on the training and long-term commitment of divers.

In the case of Tivela mactroides, a citizen science approach is relatively more robust and objective than other organisms since it considers the submission of images 
of shells collected at beaches that are subsequently unequivocally audited. Closed shells or open shells with valves still connected (Figure 3 ) indicate the recent death of the animal (SCHÄFER, 1972), as the ligament rots after a few days. Assuming that shell transport is limited, this can be an indication of the presence of clams. The possibility of transport of shells of $T$. mactroides between sandy beaches is very improbable, once, the hydrodynamics of the North Coast are not the most likely for this type of transport (SOUZA, 2012). In addition, the fragile protein shell ligament may not resist to the rolling transportation between beaches.

We asked people to take pictures of valves of $T$. mactroides still joined by ligament and stranded animals on the sand, and send these photos (via messages, comments and email) with the location (preferably with coordinates) to us. The pictures could then be confirmed as T. mactroides or not, and the location was added to a map, pointing a beach with possible occurrence of the species. The tasks required were made as easy as possible, since participants may lose interest in overly complicated tasks (MCDOUGLE; GREENSPAN; HANDY, 2011) (e.g. sampling and sieving beach sediment to retrieve living buried individuals). Once received, the organisms photographs in the pictures were identified. If the organism was unequivocally identified as $T$. mactroides, the submission was included in our database.

To reach the public, we created social media pages on Facebook, Instagram and an email address. Since the social component of engaging in research may be the largest incentive to keep participating (WEST; PATEMAN, 2016), the interaction on social media was used to maintain volunteers. The pages went up on December $18^{\text {th }}$ and were promoted to attract followers. To interact with the public and give a feedback, intending to qualify and maintain the relationship, we posted not only our pleas for photos, but educational content about Red Lists, T. mactroides, beaches and citizen science. Submissions from followers were accepted from the day the page went live to October $15^{\text {th }}$, 2018. We promoted them through mail lists, forums and messaging groups, including those of organizations with goals similar to ours, given that people that volunteer for organization are more likely to do the same for another (MCDOUGLE; GREENSPAN; HANDY, 2011). 
Even though personal numbers of the page managers were not publicly shared, they received submissions through WhatsApp. A post was spontaneously shared in Whatsapp groups, generating interest in the project. In consequence, people sent their photos to the page managers directly.

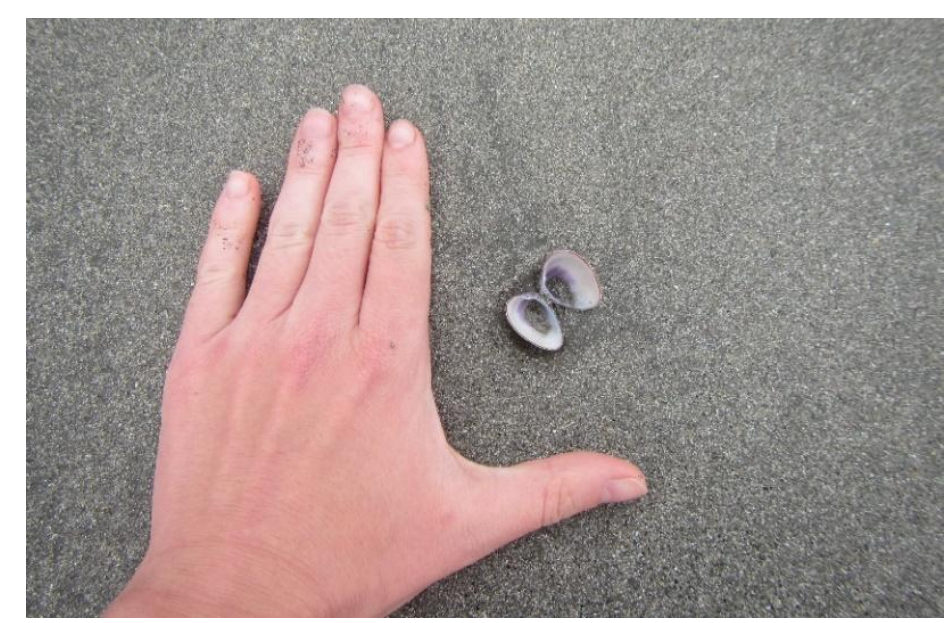

Figure 3: Two valves of Tivela mactroides still joined by ligament, interior side facing up - Barequeçaba Beach - São Sebastião. The ligament indicates recent death (Photo: Thaís Rech)

\subsubsection{Beach Visits and Shell Observation}

This a method that seeks to verify if the beaches with high SHS rank (step 3.1.3), that had no records or evidence from the other steps until here, have joined shells of Tivela mactroides indicating presence of $T$. mactroides. The base of shell observation is similar to the rationale used in the citizen science chapter 3.1.4: joined valves in the sand may indicate the presence of $T$. mactroides in that beach. The three first positions on the SHS rank $(7,6$, and 5 ) were picked (described in chapter 3.1.3) as possible targets for shell observation. The beaches with previous information on the known existence of $T$. mactroides were removed from this pool of beaches. Records and evidence from all the previous steps were considered here, Literature review (1), Data repositories and museums (2), Interviews with experts (4), Interviews with community members (5) and Citizen science (6). Assuming the older records and evidence are less of an indicative of current distribution, the beaches with records/evidence older than 2018 (similar to step 3.1.1) were not removed from the pool for shell observation.

The presence of T. mactroides shells, still joined by ligament (Figure 3), was investigated on the chosen beaches. The observation area was the strand lines on the chosen beaches, following along until the first joined shells were seen. If there were no 
visible strand lines, the area between high tide mark and low tide was observed instead. Observations were made between December, 2017 and August, 2018. Each beach was visited up to 3 times. However, beaches in which the species occur may not have exposed shells on sand. Thus, the beaches without the presence of shells may have populations that were not detected by this methodology.

3.2 Assess temporal trends in the size of populations (abundance) of Tivela mactroides on the Northern Coast of São Paulo state

In order to assess temporal trends in the size of populations (abundance) of Tivela mactroides on the Northern Coast of São Paulo state (Objective 2), three steps were taken: a literature review (1) and two sets of interviews, experts (2) and community (3), as described in Figure 2.

\subsubsection{Literature review}

This step is similar to the step described in the objective 1 related to geographic distribution of Tivela mactroides, in chapter 3.1.1. The papers found by step 3.1.1 were analyzed for temporal trends in the size of populations. A careful bibliographic survey was done on the population and ecological data of $T$. mactroides, such as its area of occupation, distribution and temporal trends in the size of populations (abundance) in the Northern Coast of São Paulo state. The search was limited to articles published until 2017 , as that was the year the search was conducted

\subsubsection{Interviews with experts}

The interviews with experts were done with the same interviewees of item 3.1.4 (Objective 1). The questions five and six (ANNEX 2) were used to identify if the size of the populations of Tivela mactroides was stable over the years, and if not, whether it decreased, increased or fluctuated over the years, considering each one the beaches they had indicated. The words were grouped and counted separately whether they meant increase, decrease or oscillation and analyzed to obtain to the trends for the future. Answers of persons that considered T. mactroides and A. brasiliana as the same species were not considered to assess the temporal trends of $T$. mactroides in the Northern Coast of São Paulo state. 


\subsubsection{Interviews with community}

The interviews with community members were also done following the procedure for Objective 1 (presented before in chapter 3.1.5), using questions eight and nine (ANNEX 4) to identify if the size of the populations of T. mactroides was stable over the years, and if not, whether it decreased, increased or fluctuated over the years, considering each one the beaches they had indicated. The questions were similar to the ones for experts (chapter 3.2.2), and question ten was open-ended, so interviewees could describe their impressions. The trends of the population size were treated by grouping the answers that expressed increase, decrease or oscillation.

3.3 Identify possible threats to clam populations on the Northern Coast of São Paulo state and their temporal trends

In order to identify possible threats to clam populations on the Northern Coast of São Paulo state and their temporal trends (Objective 3), three steps were taken: a literature review (1) and two sets of interviews, experts (2) and community (3), as described in Figure 2.

\subsubsection{Literature review}

In this step, a snowball review was then made within the articles found by step 3.2.1, following other studies that looked into possible threats to Tivela mactroides (GRANT; BOOTH, 2009; WNUK; GARREPALLI, 2018). Additionally, we searched for the terms "oil", "erosion", "climate change", "capture", "habitat loss", "pollution" in the references, each one at time. The search was limited to articles published until 2017, as that was the year the search was conducted.

\subsubsection{Interviews with experts}

The interviews with experts were also done following the snowball described in chapter 3.1.4, employing questions 7 through 17 (ANNEX 3) to identify: if they perceived any threats to Tivela mactroides, what those threats are, and if those threats would intensify, or weaken, over next the years. Interviewees could answer the questions considering the beaches they indicated the presence of $T$. mactroides or mentioning the coast as whole. 
In order to describe the threats T. mactroides from the interviews with experts, the answers (questions 7 to 17 (ANNEX 4) of the interviews) were carefully analyzed for the perceived threats to $T$. mactroides. The answers were grouped by key words that represent the threats, following the principles of concept analysis, based on and Busch et al. (2012). These results were turned into maps, so it would be possible to see spatial similarities.

The situation described in the interview, the number of citations, combined with the information obtained on literature will indicate the most eminent menaces for the conservation of $T$. mactroides. The tendencies of said threats were treated in a similar process, grouping the answers by keywords. In addition, words and expressions that expressed increase, decrease or oscillation in the intensity of threats were analyzed to obtain the potential trends for the future. The words were grouped and counted separately whether they meant increase, decrease or oscillation.

In questions twelve and sixteen, they were asked what was the possible extinction window (time-frame within which the species may be locally extinct) for $T$. mactroides. This time-frame comes from the IUCN criteria, particularly criterion E. The words were grouped and counted separately whether they meant increase, decrease or oscillation and analyzed to obtain the trends and expected time-frame of extinction in the future.

\subsubsection{Interviews with community}

The interviews with community were also done following the snowball described in chapter 3.1.5, for Objective 1, employing questions ten to 17 (ANNEX 4) to identify if they perceived any threats to Tivela mactroides, what those threats were and if those threats would intensify, or weaken, over next the years. Interviewees could answer the questions considering the beaches they indicated the presence of $T$. mactroides. The analysis of the threats was conducted in the way described in chapter 3.3.2, analyzing questions by applying the same set of keywords. Answers of persons that considered T. mactroides and Anomalocardia brasiliana as the same species were not considered to assess the threats to T. mactroides in the Northern Coast of São Paulo state. 


\section{RESULTS}

4.1 Geographic distribution of Tivela mactroides in the Northern Coast of São Paulo State

\subsubsection{Combination of methods}

The combined steps $(1-7)$ have returned a total of 59 locations (considering Iperoig and Itaguá the same feature) that have or have had populations of Tivela mactroides, as seen in Figure 5. In this map, each location presents the methods that indicated possible presence of $T$. mactroides. The results are described by beach in ANNEX 6, where they can be compared, with results from each method and the SHS. The distribution of records/evidence of the trigonal clam is very wide in the coast, spanning the four municipalities; of the 59 beaches, 26 were in Ubatuba (44,1\%), five in Caraguatatuba (8,5\%), 17 in São Sebastião (28,8\%) and ten in Ilhabela (16,9\%). The 59 beaches equal $20,9 \%$ of the all beaches analyzed, it may be possible to say that $T$. mactroides is not restricted in range in the region.

In each step, more beaches were added (Figure 4): to the initial seven obtained from literature review, more 28 where added by consultation of data repositories and collections. Interviews with experts added more six beaches with evidence of $T$. mactroides, while citizen science submissions added five, interviews with community added thirteen and shell observation, four. This results in 28 beaches with some records from literature and/or databases, and 29 with other evidence of $T$. mactroides occurrence. Caraguatatuba Bay is the place with more citations on literature (16), most submissions from citizen scientists (17), and most mentions in interviews with experts (4) and community (7).

The year that $T$. mactroides was last observed or collected in indicated in a location is shown whenever T. mactroides has not been sighted after 1998 (as established in chapter 3.1.1). Twelve $(20,7 \%)$ of the 59 beaches did not have records or evidence of T. mactroides from 1998 or more recent (ANNEX 7).

Before the beaches with evidence of presence of $T$. mactroides from Shell Observation, there is an overall trend of increasing beaches with some record or evidence of $T$. mactroides with the increase in SHS rank, as shown in Figure 4. The percentage of beaches with records and/or evidences only reaches $50 \%$ at SHS rank 5. It was decided to display only the beaches with records/evidence from 1998 on, because the beach may have changed for some of the older records. The trend is similar if older records are maintained, with the exception of the beaches classified as 1 
(which were only two). If older records are maintained, the percentage of beaches with records and/or evidences is $50 \%$ at SHS rank 1 , because there are only two beaches in this rank and one of them has an old record.

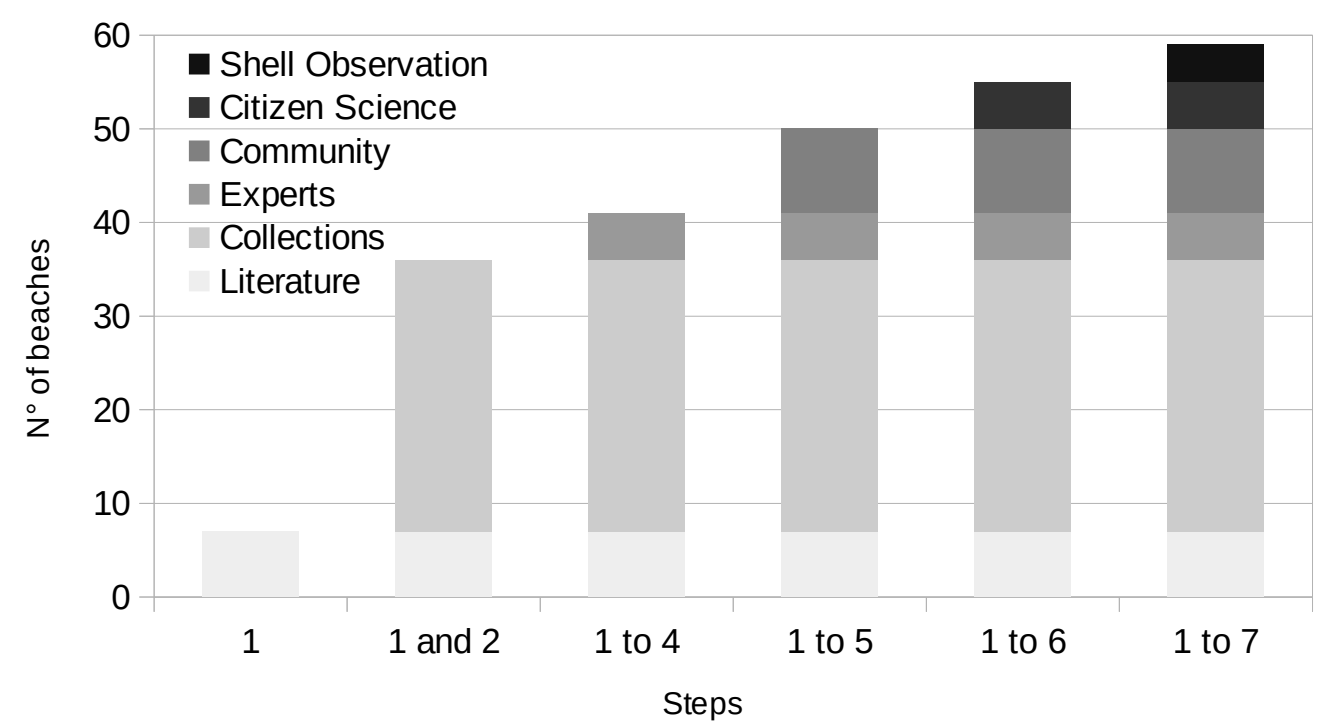

Figure 4: Number of new records/evidence of occurrence of Tivela mactroides added by each method (steps 1-7). SHS modelling is not represented (step 3). From bottom to top, all the locations that had not been indicated by the method before were counted and plotted.

\subsubsection{Literature Review}

The literature survey returned seven beaches (Fazenda, Itaguá, Caraguatatuba Bay, Araçá Bay beach, Pitangueiras, Zimbro and Barequeçaba) with records of Tivela mactroides in the Northern Coast of São Paulo, from 20 pieces of scientific literature with spatial records and one that described the clam only as from "São Sebastião Channel". Eight of the articles belong to Projeto Berbigão (http://projetoberbigao.org/), which is a research project monitoring T. mactroides in Caraguatatuba Bay since 2002 (PROJETO BERBIGÃO, 2013). Other eight studies recorded T. mactroides in Caraguatatuba Bay, and four more along the São Sebastião Channel (Figure 5; ANNEX 6). The locations found by these studies are represented in figure 5.

In six articles, T. mactroides was recorded before 1998, and oldest record being from 1973, in Ubatuba (NARCHI, 1973). The records for Pitangueiras, Zimbro and Barequeçaba are from July, 1982 to February, 1983. The other 20 articles are from 1998, or after that year (Error: Reference source not found). Of the seven beaches, four of them only had records older than 1998, and three had records newer or from 1998. 


\subsubsection{Consulting data repositories and collections}

The consultation of data repositories and museum collections returned six beaches (Fazenda, Itaguá, Caraguatatuba Bay, Araçá Bay beach, Pitangueiras and Barequeçaba) already found in the literature review, plus other 29 beaches with occurrence of Tivela mactroides, from 629 records (Figure 5; ANNEX 6). The locations are concentrated in Caraguatatuba Bay $(74,1 \%)$, with some in Ubatuba $(19,08 \%)$ and São Sebastião (4,8\%) (Figure 1), while Ilhabela was the most poorly represented municipality $(2,1 \%)$. For number of beaches with records data repositories and collections by municipality, Ubatuba is the most representative, with 16 beaches $(47,0 \%)$ of 35 beaches (Figure 1$)$.

The consultation in speciesLink returned records from Coleção de Moluscos (MCP-Moluscos), OBIS Brasil (OBIS_BR), Sistema de Informação do Programa Biota/ Fapesp (SinBiota) and Coleção de Bivalvia do Museu de Zoologia da UNICAMP (ZUEC-BIV) (SPECIESLINK, 2017), while the records from Museu Nacional de História Natural/Rio de Janeiro (MN-RIO), Natural History Museum- London (NHM-London), Museum of Comparative Zoology, Harvard University (HU-ZOO), Bailey-Matthews National Shell Museum, Florida (BMSM/Florida) and Natural History Museum Rotterdam (NHM-Rotterdam) were obtained through GBIF (OCCDOWNLOAD GBIF.ORG, 2019).

Only $80(12,9 \%)$ of the records were older than 1998; however this may be a result of the way more recent entries are registered, i.e. older records tend to be single, or only a few entries per project/collector, with a location; newer records span multiple entries, one for each coordinate where the animal was collected. 167 (26,5\%) were from or after 1998. 2001 was the year with the most records, $138(22,3 \%)$, followed by 1988, with $23(3,7 \%)$. The oldest record is from 1950 and corresponded to Itaguá Beach, in Ubatuba. Thirteen beaches' records of T. mactroides were older than 1998, other 13 were from 1998 or newer, and nine were not dated. 


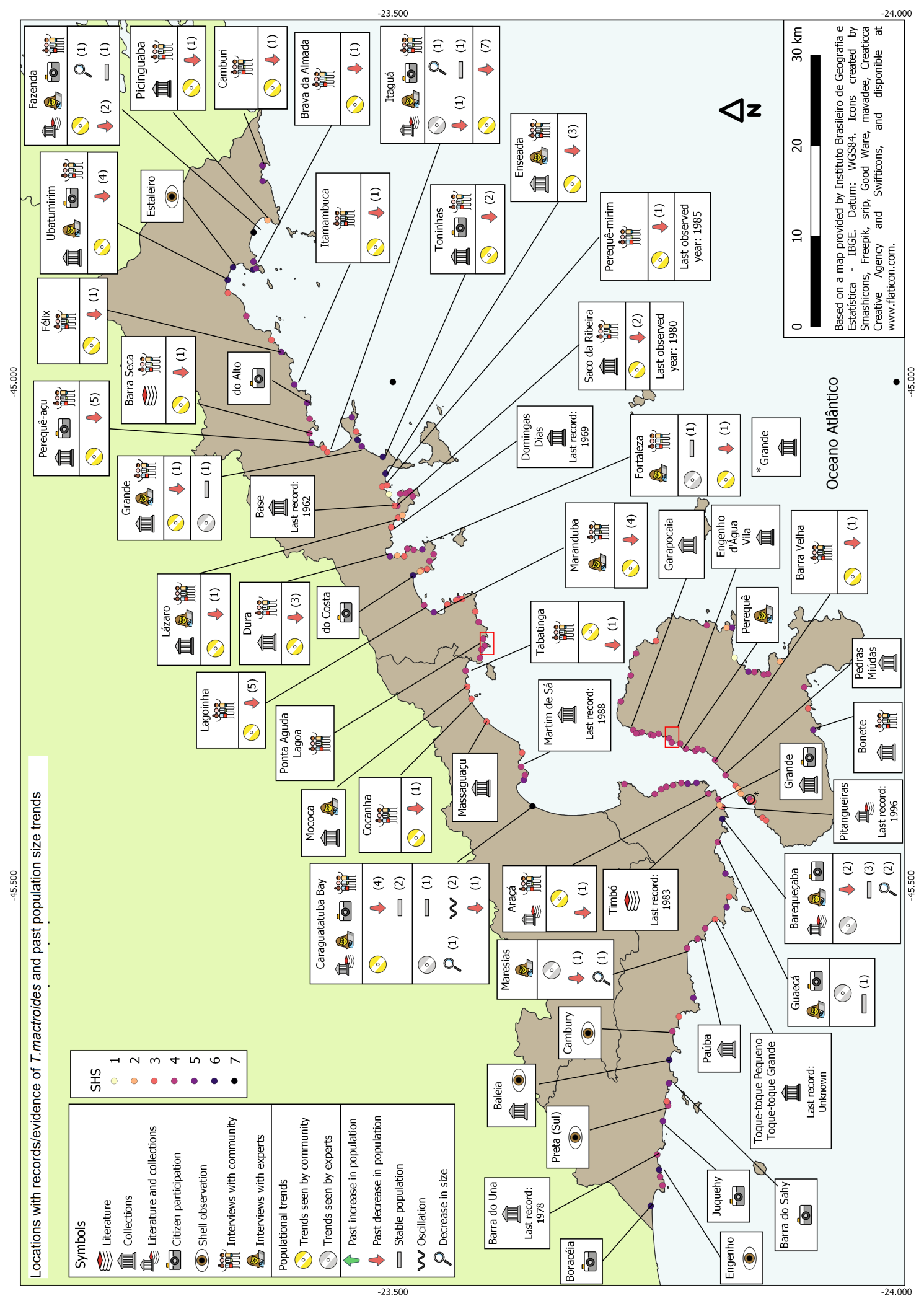

Figure 5: Locations where Tivela mactroides was recorded or has evidence of its presence in the Northern Coast of São Paulo state. The sources that lead to the record or evidence are represented by icons. The past temporal trends in the size of populations, as perceived by interviewees (experts and community), are also shown. The beaches are marked by a color dot, indicating its Simplified Habitat Suitability rank. 


\subsubsection{Habitat Suitability Modeling}

The number of beaches with potential occurrence of Tivela mactroides was estimated by the Simplified Habitat Suitability modeling and revealed that 40 beaches $(20,9 \%$ of the all beaches analyzed) were ranked 5 or above, i.e. with a relatively high possibility of occurrence (Table 2). Within all beaches with available information, three $(1,6 \%)$ scored 7 , twelve $(6,3 \%)$ scored 6 and $25(13,1 \%)$ scored 5 . The most common SHS classification was 4, with 68 beaches (35,6\%) (Table 2). Thirty-seven $(19,4 \%)$ beaches did not have information enough for SHS evaluation, resulting in unclassified locations, and are listed in ANNEX 6. The classification of all beaches in the Northern Coast of São Paulo is presented in ANNEX 8 where they are organized by SHS number and municipality, for clarity.

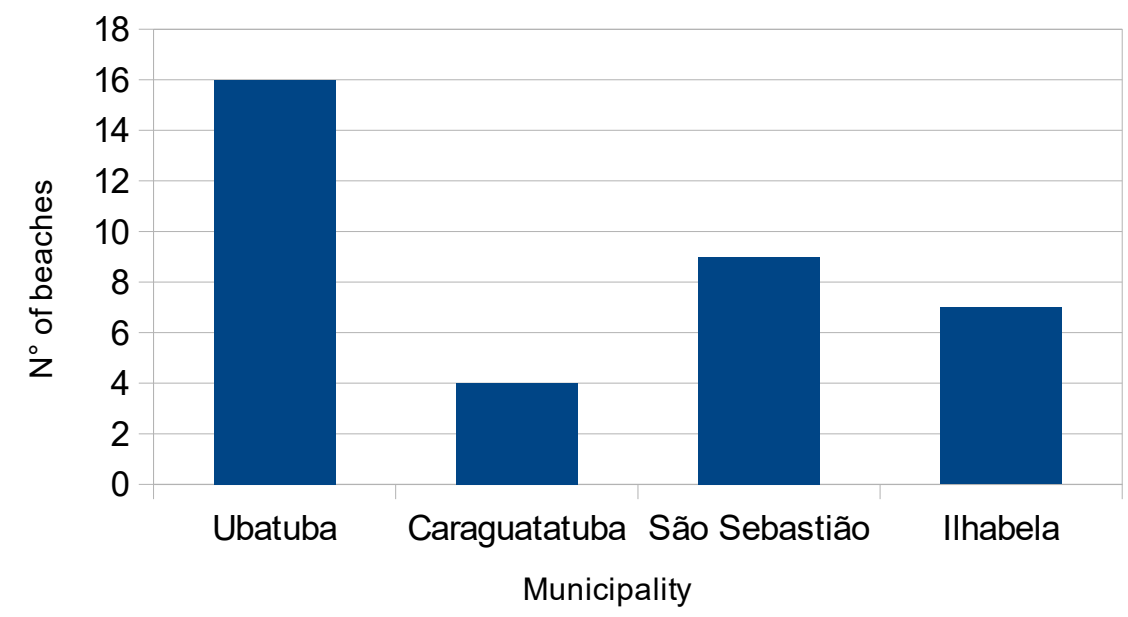

Figure 6: Number of beaches with records of Tivela mactroides in databases and collections divided by municipality. 
Table 2: Results of Simplified Habitat Suitability (only scores $>5$ shown), displaying the values for Grain Size (fine sand:3; medium, very fine:2; coarse:1), Slope (lower than $5^{\circ}: 3$; higher than $5^{\circ}$ and lower than $15^{\circ}:$, higher than $\left.15^{\circ}: 1\right)$ and Exposure (Exposed:1; Sheltered: 0), based on MAREM. The municipality is also indicated for clarity.

\begin{tabular}{|c|c|c|c|c|c|}
\hline Beach & Municipality & Grain size & Slope & Exposure & Total \\
\hline Fazenda & Ubatuba & 3 & 3 & 1 & 7 \\
\hline Preta (Costa Sul) & São Sebastião & 3 & 3 & 1 & 7 \\
\hline Caraguatatuba Bay & São Sebastião/Caraguatatuba & 3 & 3 & 1 & 7 \\
\hline Lagoinha & Ubatuba & 2 & 3 & 1 & 6 \\
\hline Enseada & Ubatuba & 2 & 3 & 1 & 6 \\
\hline Toninhas & Ubatuba & 2 & 3 & 1 & 6 \\
\hline Tenório & Ubatuba & 2 & 3 & 1 & 6 \\
\hline Itaguá & Ubatuba & 3 & 3 & 0 & 6 \\
\hline Ubatumirim & Ubatuba & 2 & 3 & 1 & 6 \\
\hline Estaleiro do Padre & Ubatuba & 2 & 3 & 1 & 6 \\
\hline Almada & Ubatuba & 2 & 3 & 1 & 6 \\
\hline Baleia & São Sebastião & 2 & 3 & 1 & 6 \\
\hline Barequeçaba & São Sebastião & 2 & 3 & 1 & 6 \\
\hline Boracéia & São Sebastião & 2 & 3 & 1 & 6 \\
\hline Engenho & São Sebastião & 2 & 3 & 1 & 6 \\
\hline Maranduba & Ubatuba & 2 & 3 & 0 & 5 \\
\hline Dura & Ubatuba & 2 & 3 & 0 & 5 \\
\hline Grande & Ubatuba & 2 & 2 & 1 & 5 \\
\hline Cedro (Cedrinho) & Ubatuba & 2 & 2 & 1 & 5 \\
\hline Perequê-Açú & Ubatuba & 3 & 2 & 0 & 5 \\
\hline Alto & Ubatuba & 2 & 2 & 1 & 5 \\
\hline Itamambuca & Ubatuba & 2 & 2 & 1 & 5 \\
\hline Félix & Ubatuba & 2 & 2 & 1 & 5 \\
\hline Engenho & Ubatuba & 2 & 3 & 0 & 5 \\
\hline Brava da Almada & Ubatuba & 2 & 2 & 1 & 5 \\
\hline Brava do Camburi & Ubatuba & 2 & 2 & 1 & 5 \\
\hline Fortaleza & Ubatuba & 3 & 2 & 0 & 5 \\
\hline Juquehy & São Sebastião & 2 & 2 & 1 & 5 \\
\hline Conchas & São Sebastião & 2 & 2 & 1 & 5 \\
\hline Barra do Sahy & São Sebastião & 2 & 2 & 1 & 5 \\
\hline Cambury & São Sebastião & 2 & 2 & 1 & 5 \\
\hline Brava de Boiçucanga & São Sebastião & 2 & 2 & 1 & 5 \\
\hline Calhetas & São Sebastião & 2 & 2 & 1 & 5 \\
\hline Brava de Guaecá & São Sebastião & 2 & 2 & 1 & 5 \\
\hline Centro & São Sebastião & 2 & 3 & 0 & 5 \\
\hline Porto Grande & São Sebastião & 2 & 3 & 0 & 5 \\
\hline Freira (Garcez) & Caraguatatuba & 2 & 2 & 1 & 5 \\
\hline Castelhanos & Ilhabela & 2 & 2 & 1 & 5 \\
\hline Eustáquio & Ilhabela & 2 & 2 & 1 & 5 \\
\hline Bonete & Ilhabela & 2 & 2 & 1 & 5 \\
\hline
\end{tabular}




\subsubsection{Interviews with experts}

Nine experts were interviewed and the dates of the interviews, how they were found and reason why these people were considered experts is in ANNEX 9. There is a prevalence of experts that work/worked in universities. The interviews with experts returned 13 locations (Figure 5) (ANNEX 6), distributed along Ubatuba (7), Caraguatatuba (2), São Sebastião (3) and Ilhabela (1). Each interviewee answered an average of 3,8 beaches (median: 3 ). The most cited beach is Caraguatatuba Bay, with eight experts mentioning it. The questions about when was that the first time the interviewees had first seen $T$. mactroides revealed that the oldest sighting by an expert was in the 1970's.

\subsubsection{Interviews with community}

Starting from the 12 locations described in step 3.1.6, 48 persons agreed to be interviewed in total, resulting in 16 locations. Of those, questions one to three showed that 27 people could not differentiate Tivela mactroides from Anomalocardia brasiliana, 19 could differentiate them and one person was not sure if they could. Only a fraction of the people we talked to differentiated between $T$. mactroides and A. brasiliana, even among fishermen, while other people seemed to conflate more species, such as Perna perna. Only the answers of the 19 that discriminated the species were considered in the results, in order to assure that the interviewee was really talking about $T$. mactroides. The list of persons interviewed, with the date, location of the interview, and if the person could distinguish T. mactroides apart from A. brasiliana is in ANNEX 10.

The interviews were not limited to the initial locations described in chapter 3.1.6, as the answers to the snowball lead us to other locations: Ubatumirim, Perequê-açú, Lázaro in Ubatuba; Cambury and Juquehy in São Sebastião; and Perequê, in Ilhabela. However, it was not possible to interview anyone in: Enseada and Barra Velha, as people did not want to participate.

Nevertheless, community interviews returned 27 beaches with $T$. mactroides (Figure 5), (ANNEX 6): seventeen in Ubatuba, four in Caraguatatuba, five in São Sebastião and two in Ilhabela. In two beaches the year of the last observation was before 1998, Perequê-mirim and Saco da Ribeira, the interviewees reported not seeing T. mactroides since 1985 and 1980, respectively. In the remaining beaches, interviewees either said they still thought $T$. mactroides was still present at the beach, or the last time they saw it was after 1998. The earliest year that an interviewee recalled seeing T. mactroides was 1964 in Lagoinha, Ubatuba. 


\subsubsection{Citizen Science}

In the social media pages (Instagram and Facebook), the page managers posted material regularly, in which social media users left comments and sent messages, reaching 812 followers in Facebook and 274 in Instagram (Table 3). From all the interactions with the followers of the pages, 47 submissions included all the required information (picture of joined valves of $T$. mactroides, date and location). These submissions will be addressed as "adequate" from now on. The adequate submissions spanned across 14 beaches in the Northern Coast of São Paulo State (Figure 5).

Seventeen of the entries were from Ubatuba, other seventeen corresponded to the Caraguatatuba Bay beaches and thirteen were from São Sebastião (Figure 7). There were five new occurrences (do Costa Beach, do Alto Beach, Barra do Sahy, Juquehy and Boracéia). The list of locations, day the picture was taken, and the name of the person who sent it is in ANNEX 11. In the case of Perequê-açu, Antônio Neto sent video of an acquaintance harvesting T. mactroides for a meal, and Camila Luvizaro also sent us a picture of fresh $T$. mactroides. Some people only sent verbal descriptions (or other comments out our requirements for a submission) of the locations where T. mactroides can be found and this type of submission was called "other clues" (Table 3). They were not counted in the total of submissions.

Even though personal numbers of the page managers were not publicly shared, they received eleven submissions through WhatsApp, eight of them were adequate. This happened because some material from the pages was shared by WhatsApp, either by managers or by others, and people decided to contact the managers through this medium. Of the established media, Facebook was the medium we obtained the largest engagement by total number of adequate submissions and followers (Table 3 ). However, the proportion of adequate of submissions in Instagram was relatively higher compared to the number of followers, even if the percentage of adequate submissions was relatively lower in comparison to Facebook. The email was useful for setting up services and receiving material, but people did not send submissions using this medium. 


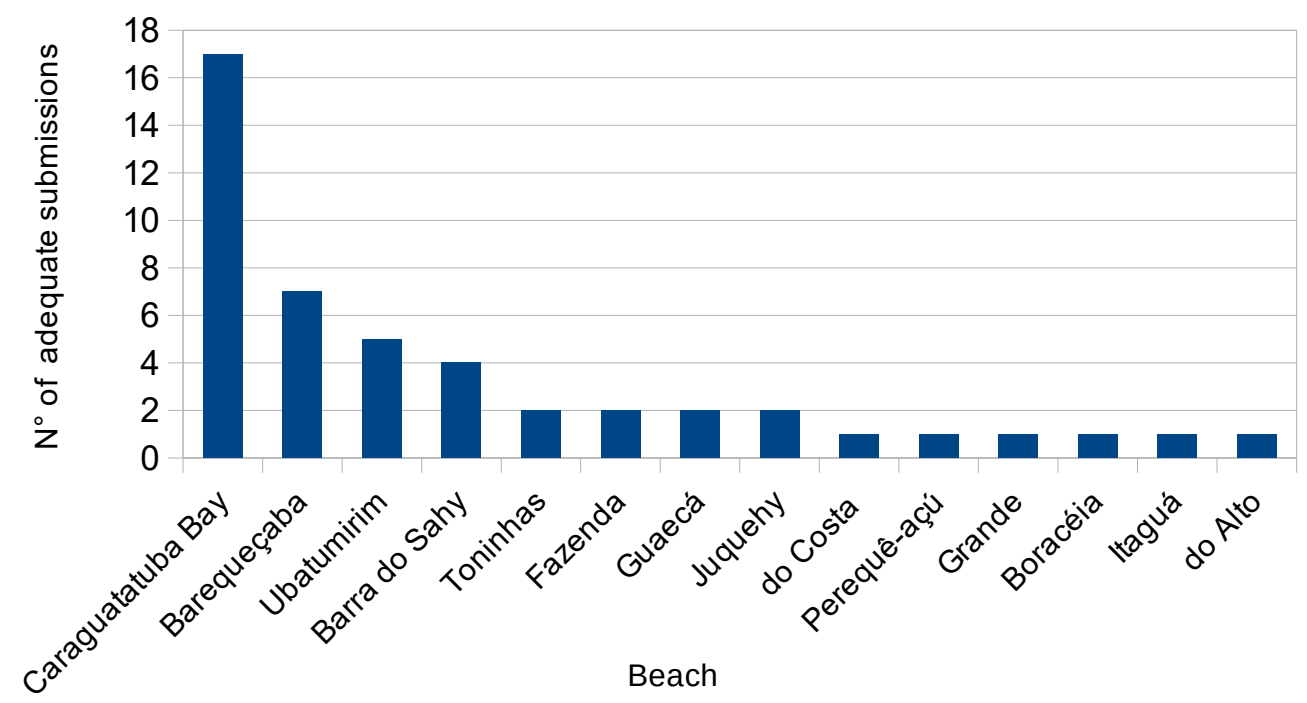

Figure 7: Number of adequate submissions of pictures of Tivela mactroides from citizen scientists, grouped by beach. The "Grande" beach is in São Sebastião.

Table 3: Interactions with citizen scientists through the project's social media (Facebook, Instagram and Whataspp) pages. Adequate submissions are the ones that follow the guidelines, total submissions are all picture submissions, and other clues are written indications of where Tivela mactroides might be found.

\begin{tabular}{|l|l|l|l|l|l|}
\hline Medium & Followers & $\begin{array}{l}\text { Adequate } \\
\text { submissions }\end{array}$ & $\begin{array}{l}\% \text { of adequate } \\
\text { submissions }\end{array}$ & $\begin{array}{l}\text { Total } \\
\text { submissions }\end{array}$ & $\begin{array}{l}\text { Other } \\
\text { clues }\end{array}$ \\
\hline Facebook & 812 & $23^{*}$ & 58,97 & 39 & 18 \\
\hline Instagram & 274 & $16^{*}$ & 51,61 & 31 & 21 \\
\hline Whatsapp & - & 8 & 72,73 & 11 & 4 \\
\hline Total & - & 47 & 58,02 & 81 & 43 \\
\hline
\end{tabular}

*There was a doubled submission on Facebook and Instagram that corresponded to the same photo. It was counted under Instagram because it was the place the photo was seen by the page managers first.

\subsubsection{Beach Visits and Shell Observation}

After removing all the beaches identified by previous steps (literature review (1), databases (2), citizen science (4) and interviews (5 and 6)) from the list of beaches with rank SHS 5 or above, the following beaches remained: Estaleiro do Padre; Preta (da Costa Sul); Engenho (São Sebastião); Baleia; Cambury (São Sebastião); Centro (São Sebastião); Porto Grande; Tenório and Almada. These were the beaches in which the shell observation method was conducted.

Shells were found in Estaleiro do Padre, Preta (da Costa Sul), Engenho (São Sebastião), Baleia and Cambury (São Sebastião). In these locations, the characteristics (slope and/or grain size) seemed similar what to was described by SHS. Additionally, intact animals were found in Estaleiro do Padre. No additional evidence 
(joined valves) of Tivela mactroides was found in the other beaches. They seemed to have characteristics less adequate than expected (steeper slopes and/or coarser sand), which might be a result of the natural beach variability (either seasonal or tidal state) or problems with the sources used for SHS. Centro and Porto Grande were urbanized beaches, with seawalls and ramps, while Almada and Tenório were regularly raked, removing any shells from the sand - situations that may have interfered with shell observation.

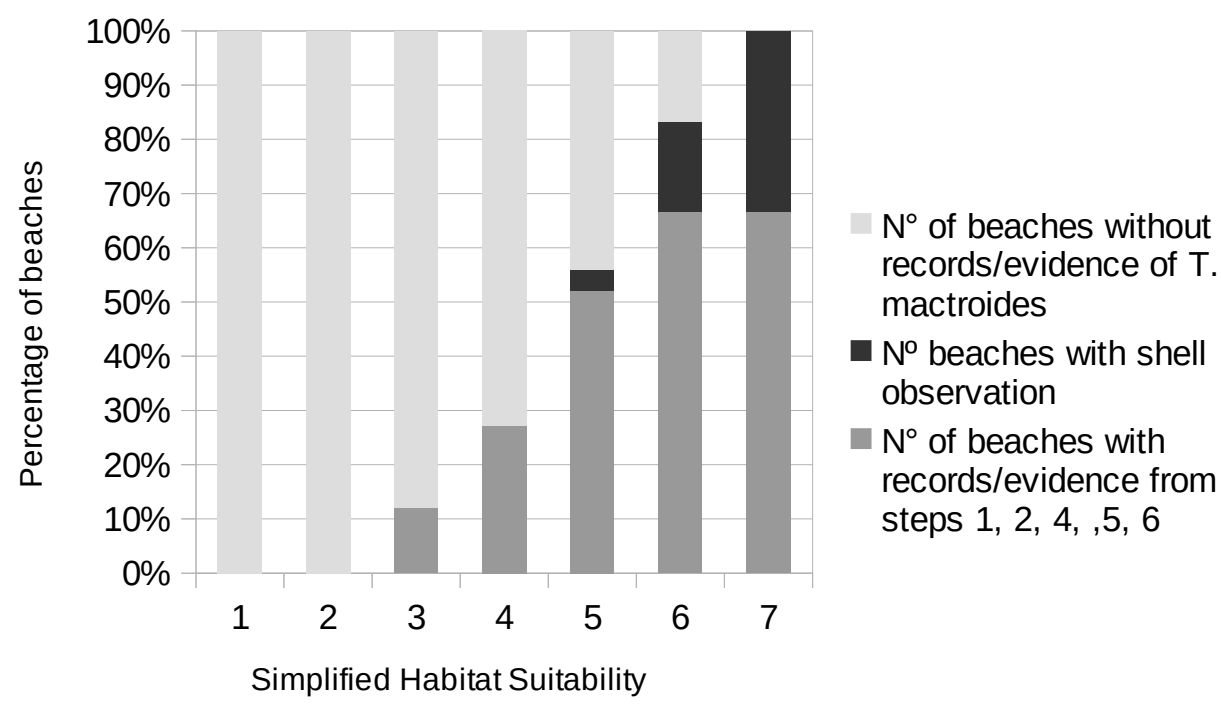

Figure 8: The percentage of beaches with and without records (literature review, data repositories and museums, interviews with experts and community and citizen science) of Tivela mactroides by Simplified Habitat Suitability class, considering only records and evidence from or after 1998. Shell observation is shown separately, since it was only performed in beaches with a SHS rank above 5.

4.2 Temporal trends in the size of populations (abundance) of Tivela mactroides on the Northern Coast of São Paulo state

\subsubsection{Literature Review}

In the papers located by the literature review, the only location with long-term monitoring for population size, abundance, and population structure is in Caraguatatuba Bay, conducted by Projeto Berbigão. A study by Turra et al. (2016b) showed that Tivela mactroides was subject to exposure mortality in Caraguatatuba Bay, ending up "stranded" out of the sand; this risk being higher in situations with higher hydrodynamic exposure, which may be a result of the seasonal changes of beach dynamic (YOKOYAMA; SIEGLE, 2013). This type of mortality appears to be density-dependent, leading to mass mortalities and creating population control 
mechanism (TURRA et al., 2016b), meaning the population of T. mactroides markedly oscillates over time.

In spite of the variations in intra and interannual abundance of this clam (TURRA et al., 2015), no long term population growth or decrease was found by the Projeto Berbigão (TURRA et al., 2014; TURRA et al., 2016b) in beaches of Caraguatatuba Bay. No studies describing temporal population trends for the other beaches of the Northern Coast of São Paulo were found.

\subsubsection{Interviews with experts}

Of the nine experts interviewed, four experts said that at least one of the beaches presented temporal change in population size. As represented in the Figure 5, two experts indicated that Tivela mactroides population in Barequeçaba had decreased, and one expert indicated that population had also decreased in Iperoig/Itaguá, Grande (Ubatuba) and Maresias. Other two experts reported seeing oscillation in the population of Caraguatatuba Bay. Five of them answered that there were no changes in the population of $T$. mactroides for at least one beach. Question five was open-ended, allowing two experts to say they also notice decrease in body size over the years.

One expert reported said that there was no T. mactroides in Caraguatatuba Bay (last year it was seen: 2013) and one reported not seeing T. mactroides in Barequeçaba (last year: 2015). Five interviewees said they did not know if the clam was still present for at least one beach (Fazenda, Ubatumirim, Itaguá, Lazaro, Caraguatatuba bay and Barequeçaba). In all the cases, the last year T. mactroides was seen is after 1998 (ANNEX 7).

\subsubsection{Interviews with community}

After the answers were analyzed, it was decided to unify the beaches of Ubatuba Bay, (Itaguá and Centro/lperoig), in Ubatuba, as they shared many of the processes. From the 19 interviewees, 17 answered that there was some change in past population sizes. The general trend was negative, as of the 27 beaches for which question nine had at least one answer, 24 had at least one answer saying the population of Tivela mactroides has decreased (Figure 5). The beach with the most answers is Caraguatatuba Bay, with four answers saying the population has decreased over the years, and two that it did not change. Since question ten was open-ended, one community member said they also noticed decrease in body size over the years. 
4.3 Possible threats to clam populations on the Northern Coast of São Paulo

\subsubsection{Literature Review}

The papers retrieved by literature review were analyzed, searching for possible threats. Because very few studies addressed threats in the Northern Coast of São Paulo, papers that studied threats to Tivela mactroides in other regions of Brazil and in Venezuela, and a paper that reviewed threats to beach clams worldwide were added. The work by Defeo et al. (2008) is a review of literature on threats to clams of sandy beaches in the world. The conclusions of the articles found are summarized below:

Table 4: Threats found in Literature review: to T. mactroides in the Northern Coast of São Paulo State, to T. mactroides in general and to beach clams, as described by Defeo, et al. (2008).

\begin{tabular}{|c|c|c|}
\hline $\begin{array}{l}\text { Reference on potential } \\
\text { threats to Tivela } \\
\text { mactroides in the region }\end{array}$ & Threats to Tivela mactroides & $\begin{array}{l}\text { Threats to beach clams (DEFEO et } \\
\text { al., 2008) }\end{array}$ \\
\hline \multirow[t]{8}{*}{$\begin{array}{l}\text { Contamination from waste } \\
\text { water (DENADAl et al., } \\
\text { 2015) }\end{array}$} & $\begin{array}{l}\text { Contamination by heavy } \\
\text { metals from polluted sediments } \\
\text { (ACOSTA; LODEIROS, 2014; } \\
\text { SARDI; RAMOS; GARCÍA, } \\
\text { 2012) }\end{array}$ & $\begin{array}{l}\text { Metal contamination from waste } \\
\text { water; }\end{array}$ \\
\hline & \multirow{3}{*}{$\begin{array}{l}\text { Capture in Venezuela } \\
\text { (ARRIECHE; PRIETO, 2006) }\end{array}$} & Artisan capture; \\
\hline & & Oil spills; \\
\hline & & $\begin{array}{l}\text { Beach grooming (e.g. raking the } \\
\text { sand, often with heavy equipment); }\end{array}$ \\
\hline & \multirow{4}{*}{$\begin{array}{l}\text { Oil spills (SARDI; RAMOS; } \\
\text { GARCÍA, 2012). }\end{array}$} & Trampling; \\
\hline & & Beach nourishment; \\
\hline & & $\begin{array}{l}\text { Seawalls and coastal armoring } \\
\text { structures; }\end{array}$ \\
\hline & & Invasive invertebrates. \\
\hline
\end{tabular}

Conversely, a study by Turra et al. (2016) indicated that clam harvesting at current levels presented no threat to the populations of $T$. mactroides in Caraguatatuba Bay; however, an increase could be harmful. 


\subsubsection{Interviews with experts}

The interviews were analyzed for terms and phrases that represented threats, and from these terms a set keywords were defined, according Busch et al. (2012). The threats were them classified into one of the keywords in Table 5.

Of the nine experts interviewed, eight said that there are threats to $T$. mactroides, considering specific beaches or the coast in general: three of them answered considering the threats for the coast as a whole, two answered considering individual beaches, two gave answers for both and one did not how to answer. The answers are summarized in Figure 11 and in Table 5. One expert said that they did see significant threats to T. mactroides in the Northern Coast of São Paulo state. The combined answers are presented in Figure 10, grouped by beach and coast as whole.

Waste water was cited seven times (in total) by four experts, while oil was cited five times by two experts. Erosion was mentioned seven times by experts. Climate change was mentioned by three experts as threat to the maintenance of $T$. mactroides, affecting the whole coast. Population increase was cited by five experts as a threat for the entire region. Deforestation related causes appeared once. One expert said that beaches with similar characteristics (exposed/sheltered, urban/rural) were exposed to similar threats, while other highlighted the impact of changes in the water flow and sedimentation of any beach.

Additionally, one of the experts cited the disturbance caused by by-catch of Callianassid shrimp as factor affecting $T$. mactroides, adding that it is particularly important in long beaches (e.g. Boracéia, Maranduba, Dura). Another added that, while the Caraguatatuba City programs may have left the beach cleaner, the beaches of Caraguatatuba Bay are subject to compaction from the tractors that clean the sand. Clams could also be crushed by the compact sediment.

For the 13 beaches identified by experts, in six of them there is the perception that threats are going to become more intense in the future. Human occupation is shown in four beaches. Some of the tendencies foreseen hinge on factors that depend of public action: four experts perceived climate change as an important feature in how the threats will change in the future, and two said how the public power will manage the sewage system will have in waste water impact. Caraguatatuba Bay is in a particular situation, as an expert pointed out that the improvement of waste water collection and treatment may have alleviated the current situation some sectors of the beach, mostly closer to the city center. However, one person said the contamination by waste water was worsening closer to Porto Novo and Enseada. 
Table 5: List of possible threats to Tivela mactroides mentioned for the Northern Coast of São Paulo and their description. The number of interviewees citing each threat, the number of beaches and number of citations for the entire coast is shown by experts $(E)$ and community (C). The percentages shown in parenthesis, in the case $N^{\circ}$ of interviewees citing this threat and in the $N^{\circ}$ of citations of this threat for the whole coast are in relation to the total number of interviewees, and in the $N^{\circ}$ of beaches for which this threat was cited are in relation to the number of beaches these groups mentioned.

\begin{tabular}{|c|c|c|c|c|c|c|c|}
\hline \multirow[t]{2}{*}{ Threat } & \multirow[t]{2}{*}{ Definition } & \multicolumn{2}{|c|}{$\begin{array}{c}\mathrm{N}^{\circ} \text { of } \\
\text { interviewees } \\
\text { citing this threat }\end{array}$} & \multicolumn{2}{|c|}{$\begin{array}{c}\mathrm{N}^{\circ} \text { of beaches for } \\
\text { which this threat } \\
\text { was cited }\end{array}$} & \multicolumn{2}{|c|}{$\begin{array}{c}\mathrm{N}^{\circ} \text { of citations of } \\
\text { this threat for the } \\
\text { whole coast }\end{array}$} \\
\hline & & $\mathrm{E}(\%)$ & C (\%) & $\mathrm{E}(\%)$ & C (\%) & $\mathrm{E}(\%)$ & C (\%) \\
\hline Oil spill & $\begin{array}{l}\text { Concepts and ideas related to oil spills, } \\
\text { including "boats" and "boat leaks", fuel, } \\
\text { and "Petrobrás"; }\end{array}$ & $2(22,2)$ & $6(31,6)$ & $3(23,1)$ & $5(18,5)$ & $2(22,2)$ & $2(10,5)$ \\
\hline Litter & $\begin{array}{l}\text { Descriptions that fit litter or other solid } \\
\text { waste; }\end{array}$ & $1(11,1)$ & $3(15,8)$ & $1(7,7)$ & $3(11,1)$ & $1(11,1)$ & $0(0)$ \\
\hline Waste Water & $\begin{array}{l}\text { Direct description of sewage, effluent } \\
\text { treatment and effluent disposal unities } \\
\text { and closely related words; }\end{array}$ & $4(44,4)$ & $9(47,4)$ & $2(15,4)$ & $11(49,7$ & $2(22,2)$ & $2(10,5)$ \\
\hline $\begin{array}{l}\text { Other } \\
\text { pollutants }\end{array}$ & $\begin{array}{l}\text { Explicit mentions of the concept of } \\
\text { pollution, if not specified with other } \\
\text { qualifiers of source (e.g: "sewage", } \\
\text { "boat"), or related ideas, such as "dirt", } \\
\text { and mentions of chemicals that did not } \\
\text { fit other descriptors (such as paints and } \\
\text { soaps); }\end{array}$ & $3(33,3)$ & $\begin{array}{l}10 \\
(52,6)\end{array}$ & $1(7,7)$ & $8(29,6)$ & $2(22,2)$ & $6(31,6)$ \\
\hline $\begin{array}{l}\text { Compaction/ } \\
\text { Crushing }\end{array}$ & $\begin{array}{l}\text { Situations describing threats where } \\
\text { there is danger of the clams being } \\
\text { trampled, crushed or broken; }\end{array}$ & $1(11,1)$ & $2(10,5)$ & $4(30,8)$ & $3(11,1)$ & $1(11,1)$ & $0(0)$ \\
\hline $\begin{array}{l}\text { Coastal } \\
\text { structures }\end{array}$ & $\begin{array}{l}\text { Descriptions of coastal structures, } \\
\text { including piers, marinas and seawalls; }\end{array}$ & $1(11,1)$ & $5(26,3)$ & $0(0)$ & $2(7,4)$ & $1(11,1)$ & $2(10,5)$ \\
\hline Erosion & $\begin{array}{l}\text { Any mentions of the process of erosion } \\
\text { itself, or implied through closely related } \\
\text { words and concepts; }\end{array}$ & $3(33,3)$ & $0(0)$ & $4(30,8)$ & $0(0)$ & $3(33,3)$ & $0(0)$ \\
\hline Deforestation & $\begin{array}{l}\text { Mentions of removal of mangroves, } \\
\text { forest cover, and "jundu", or other type } \\
\text { of "restinga"; }\end{array}$ & $1(11,1)$ & $1(5,3)$ & $0(0)$ & $2(7,4)$ & $1(11,1)$ & $1(5,3)$ \\
\hline Capture & $\begin{array}{l}\text { Mention of ideas of removal the clam } \\
\text { from its habitat, such "extraction", "too } \\
\text { many people exploiting it", or capture } \\
\text { that "did not follow traditional customs"; }\end{array}$ & $3(33,3)$ & $5(26,3$ & $1(7,7)$ & $2(7,4)$ & $1(11,1)$ & $2(10,5)$ \\
\hline $\begin{array}{l}\text { Population } \\
\text { Increase }\end{array}$ & $\begin{array}{l}\text { This is a very broad category, that } \\
\text { encompasses simple "human presence" } \\
\text { (when trampling or waste was not } \\
\text { clearly implied), "human occupation", } \\
\text { "real estate speculation" (often meaning } \\
\text { urban expansion), "more people" and } \\
\text { related ideas. This category is linked } \\
\text { with tourism; however, tourists were not } \\
\text { always directly implied, or were treated } \\
\text { as the same group of people that } \\
\text { moved to the region more recently; }\end{array}$ & $5(55,6)$ & $5(26,3$ & $3(23,1)$ & $3(11,1)$ & $1(11,1)$ & $5(26,3)$ \\
\hline Others & $\begin{array}{l}\text { Threats that did not fit any category and } \\
\text { were not mentioned enough times to } \\
\text { warrant a category for themselves. They } \\
\text { were sand removal, and intrinsic } \\
\text { characteristics of the beach. }\end{array}$ & $2(22,2)$ & $3(15,8)$ & $5(38,50$ & $3(11,1)$ & $2(22,2)$ & $1(5,3)$ \\
\hline
\end{tabular}


The perspectives of the possibility of local extinction and its time-frame are shown in Figure 12. Three experts answered that there was no possibility of extinction of $T$. mactroides, two answered they did not know and four answered it could be extinct in at least one of the beaches. The extinction horizons described by the experts indicate disappearance within a century is indicated for eight beaches, and within 20 years for two (Figure 11). For the entire coast, there is one answer indicating no foreseeable extinction scenario and one in hundred years.

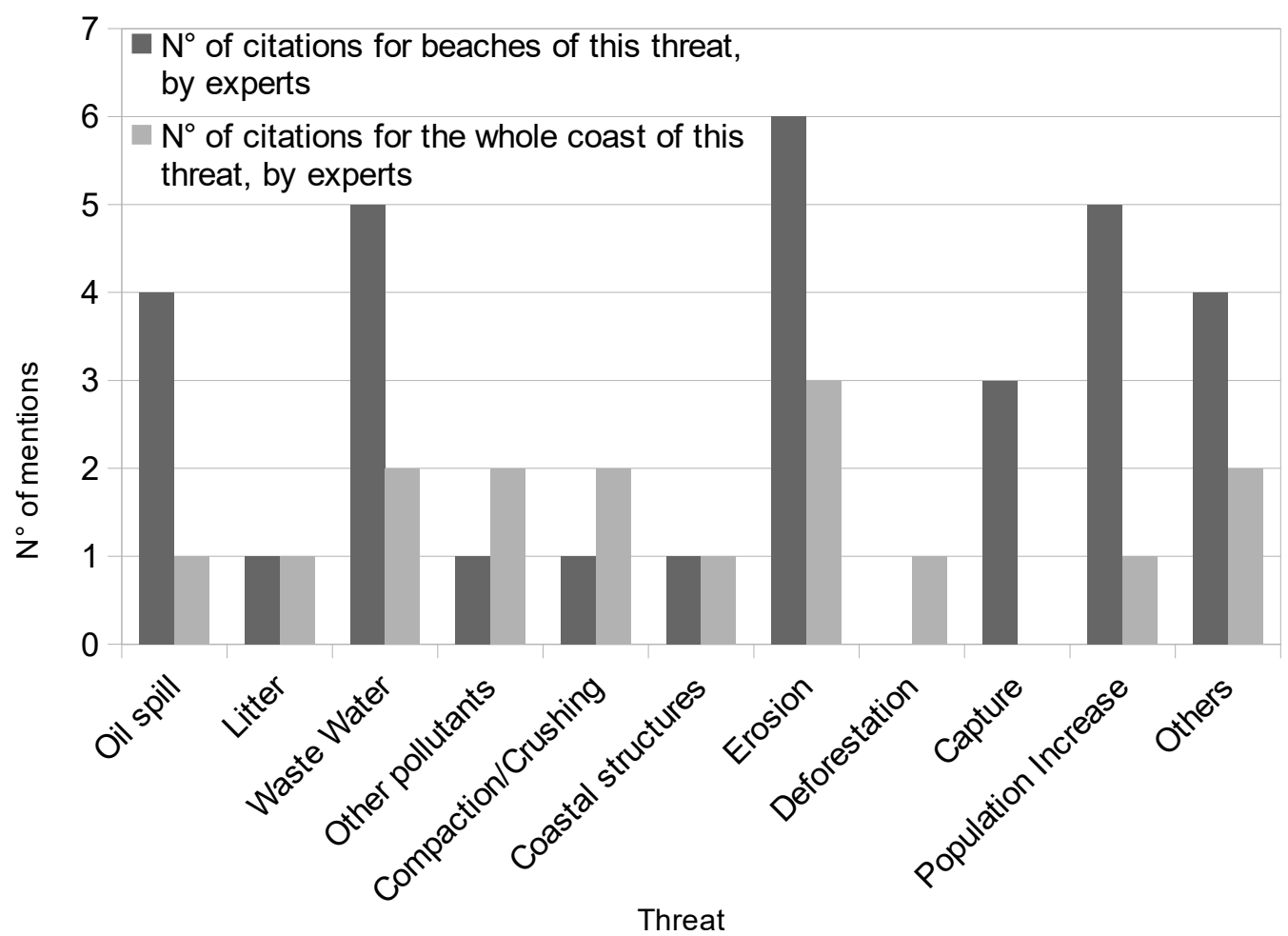

Figure 9: The differences in perceived threats by the experts that talked about threats in terms of the whole coast (light gray) and the experts that specified threats by beach (dark gray). An experts may have answered the questions considering both specific beaches and the whole coast. The threats are shown in terms of times they were mentioned.

\subsubsection{Interviews with community}

Eighteen of the 19 of community members said there were threats to Tivela mactroides. The threats were sorted into the same groups described in the interview with experts (Table 5). This is shown in Figure 9; problems with pollution (Oil, Waste water, Other pollutants) were the most cited by local community. Considering only the answers by beach, pollution related keywords and ideas were dominant: 16 citations for "Other pollutants" (pollution in general), 19 for sewage or waste water, and 12 for oil spills -6 of those referring to boats (at least one of them also showing concern for the destination of sanitary deject from boats). Sewage was a big concern in the region, with 
15 beaches with waste water and/or other pollutants listed as threats for them. Moreover, coastal structures were cited seven times for individual beaches, and twice for the whole coast. The threats cited by community members were summarized in Figure 11 and in Table 5.

The preoccupation with human presence is evident from the seven times that population increase is cited. Even though it was almost impossible to differentiate when interviewees meant tourists, new inhabitants or simply population growth, tourists were clearly cited five times. A community member pointed out that the improvement of waste water collection and treatment may have alleviated the current situation in some sectors of the beach, mostly closer to the city center.

Capture appeared seven times in specific beaches, and it was focused in Caraguatatuba Bay (three mentions). There were two other mentions for capture for the whole coast. In Barra Seca, one interviewee noted that the pollution and human occupation have increased a lot, and at the same time the abundance of $T$. mactroides decreased. Four people cited other chemical compounds as source of impact, such as cleaning products and boat paints, wondering if they would not be a bigger threat than sewage itself, specially in Itaguá. Deforestation and litter appear four and three times, respectively. One interviewee cited possible sand extraction in the beaches of Northern Coast of São Paulo, and this was included as "Others".

The perspectives of threats trend for the future are shown in Figure 12. The perception is that the threats will be stronger in ten of the beaches, with increases in intensity of waste water disposal, oil spills and other pollutants, often fueled by population increase. Not all beaches follow this trend: two people considered Saco da Ribeira to be degraded to the point it only can improve. One person said that threats will decrease because the tourism cycle is saturating and soon the region will lose touristic potential, attracting fewer visitors. Prospects described for Cocanha are improving and are stable in Mococa. 


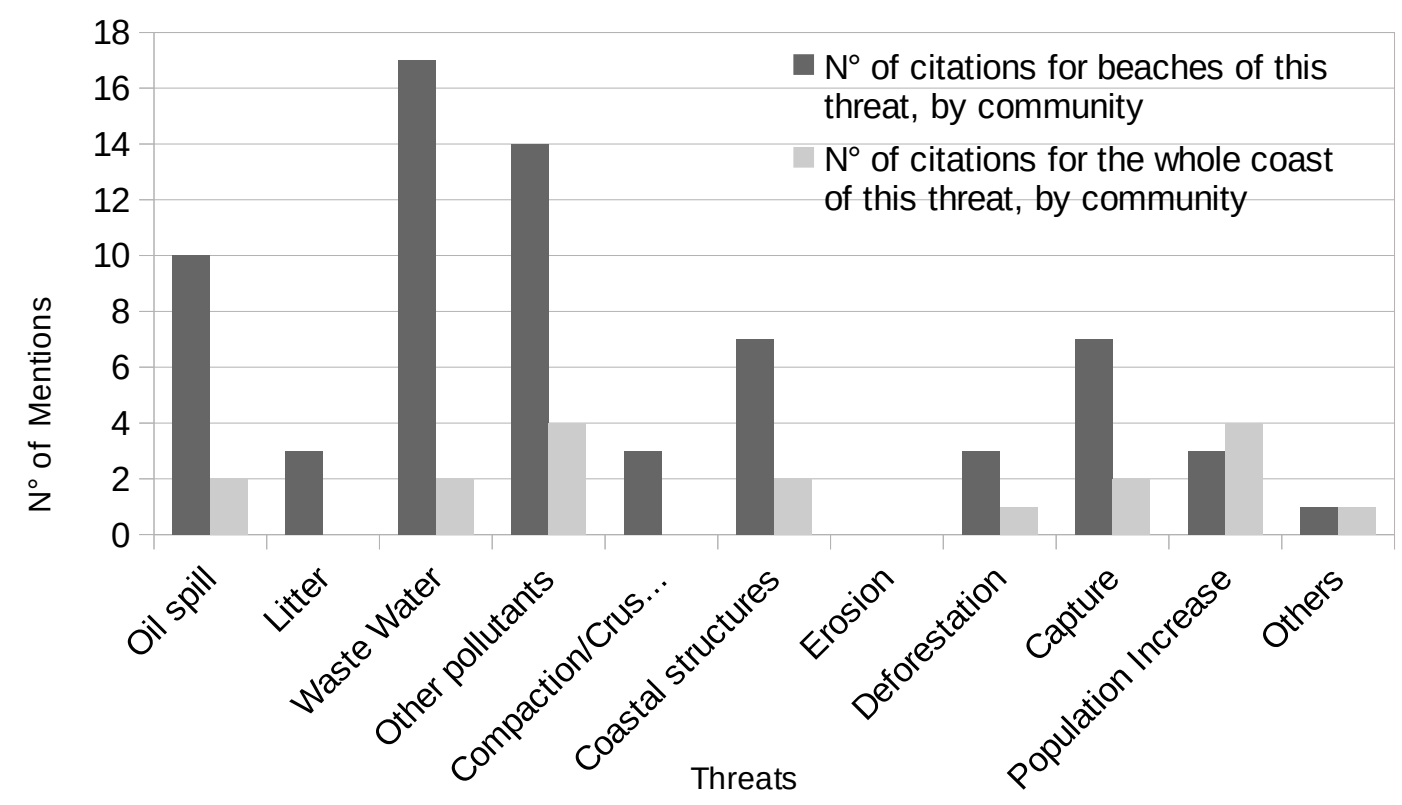

Figure 10: The differences in perceived threats by the community members that talked about threats in terms of the whole coast (light gray) and the members that specified threats by beach (dark gray). Community may have answered the questions considering both specific beaches and the whole coast. The threats are shown in terms of times they were mentioned. 


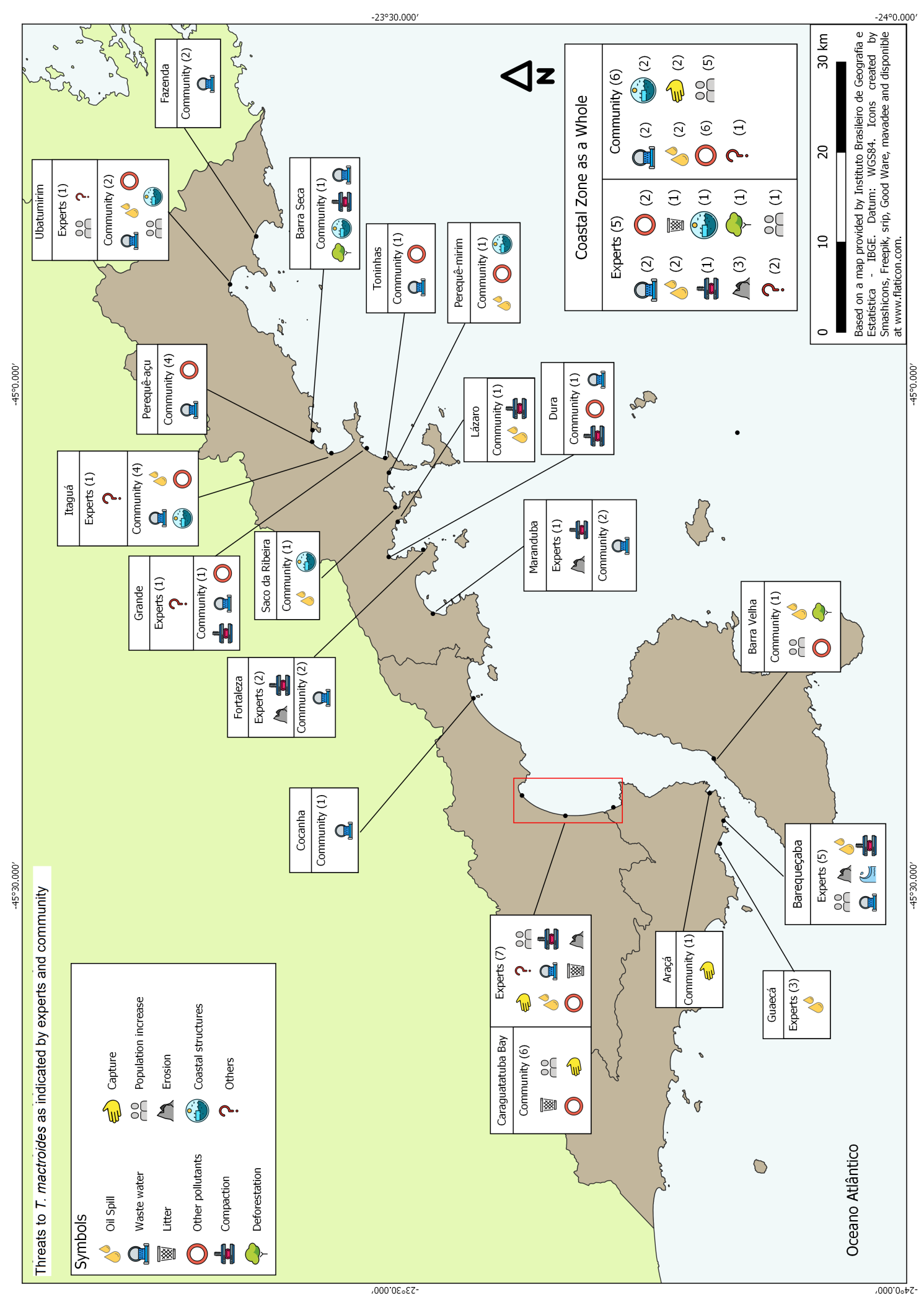

Figure 11: Threats to Tivela mactroides in the Northern Coast of São Paulo state described by community and experts, grouped by beach. In parenthesis, the number of people that have mentioned the threat. 


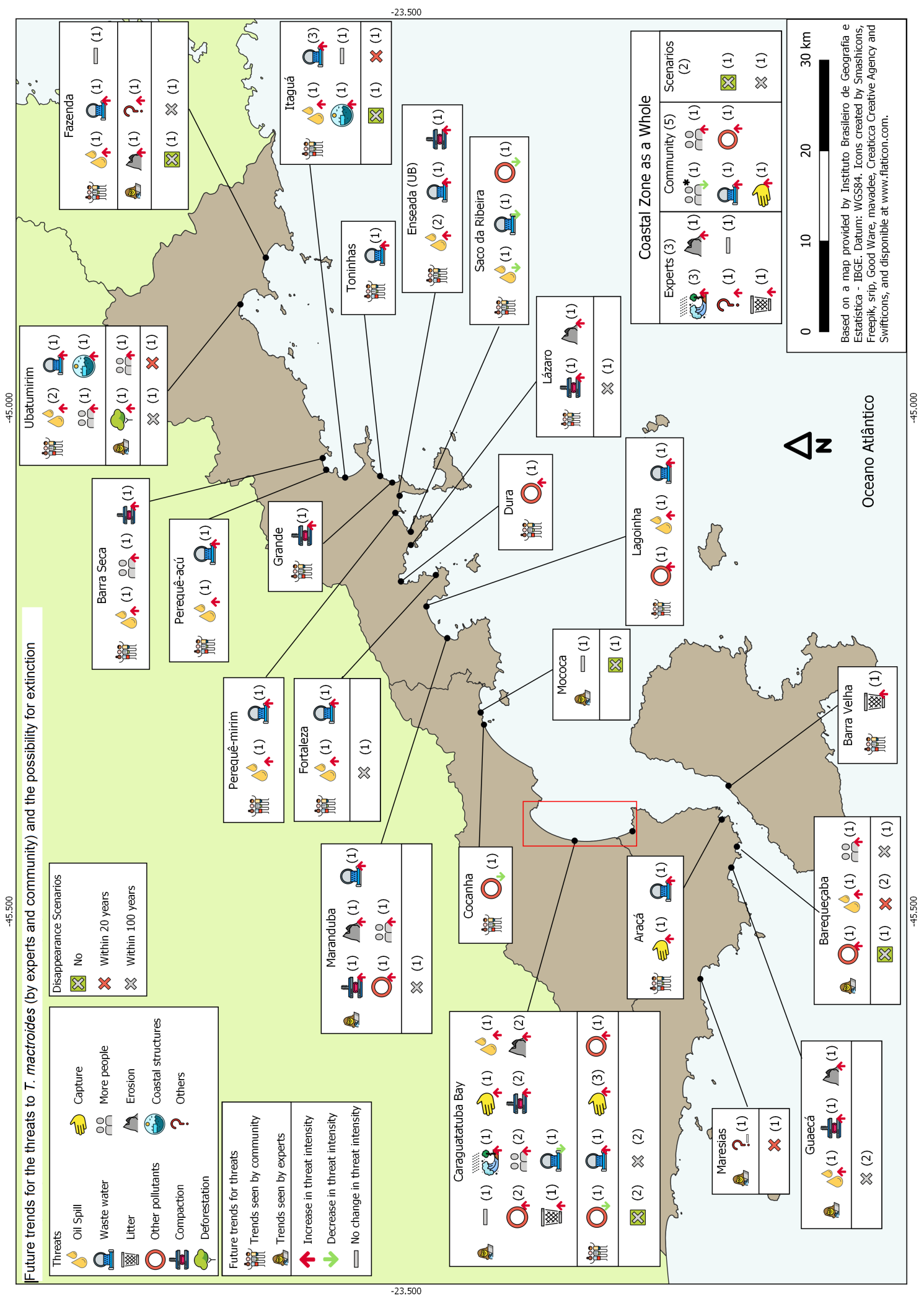

Figure 12: Future tendencies of the threats to Tivela mactroides, as perceived by interviewees (experts and community), and the time-frame within T. mactroides is expected to be locally extinct, by beach and the perceived extinction horizon. The arrows indicate if the threat is expected to become more intense, less intense or stable in the future. 


\section{DISCUSSION}

5.1 Application of the stepped approach in Geographic distribution for red list management

After putting in practice all the methods, it is possible to compare how well they performed in relation to each other and to more traditional ones. Table 6 summarizes the comparisons between them. Scientific literature may be limited depending on the species, but the species is professionally identified and this should offer more certainty. Scientific literature offers other information that is important for the creation of lists of endangered species. Depending on the region and of the species in question, the age of the studies may be an issue, as they can be too old to be relevant to the current distribution. Ideally, all information regarding distribution of a species should be be validated by scientific literature.

As for data from repositories, it has been shown that natural history collections and museums are useful for conservation planning (GRAHAM et al., 2004), especially digitized and online museum databases (BALKE et al., 2013). Databases are relevant for species with apparent lack of information, specially those in the Data Deficient category, as $40.9 \%$ of species of the Brazilian plants listed as Data Deficient have records in data repositories (SOUSA-BAENA; GARCIA; PETERSON, 2014). While very helpful, database records tend to skew towards temperate regions, particularly for long-term monitoring programs, as shown by Collen et al. (2008) for GBIF. This spatial bias may reduce the quality of models derived from them (BECK, et al., 2014), impacting their usability in conservation actions. The use of local collections may alleviate the bias created by data repositories.

The Habitat Suitability method can be used to estimate the region with adequate habitat for the target species, allowing the managers and scientists behind the list to focus their attention to areas more likely to host the species. However, the quality of the modeling depends on the quality of the data in which it was based. If the sedimentologic and morphological data are insufficient or wrong, as is found in some regions, Habitat Suitability model will be inadequate too. It is on the discretion of the managers of the red list to apply HS to a region, depending on the information available.

Interviewing experts is an interesting method, particularly if there are occurrences of the species that are unpublished. Depending on the species and the region in question, there may be few experts to interview. However, the scientific name of the species can be used, which avoids the ambiguity of popular names, and the 
questions can be more technically worded.

All this contrasts with the interviews with community, when different popular names can cause confusion, but a larger group can be interviewed. Other problems may arise when interviewing the community, including unwillingness to participate and unfamiliarity with the species. Since interviewing community members can be time consuming and has costs, this method may be not as advantageous as collecting specimens depending on how much effort it takes to collect the species.

In this study, the social media efforts also have been opportunities for outreach and environmental education even if that was not the intended objective (as exemplified in Figure 13). These contacts may improve the public's environmental knowledge. Previous work has used observational for Red List evaluation and for conservation strategies, as the work with eBird, a citizen science app (SULLIVAN et al., 2017). Some posts became popular or "went viral", which was an opportunity to engage the audience, particularly if the process was organic (I. e. was not paid to be promoted). This emulates what Unell and Castle (2012) reported in volunteering, when word-of-mouth is an effective way of recruiting.

Regardless of the capacity of the alternative methods in identifying beaches with the targeted species, they do not replace the certainty offered by sources that include collection of specimens (such as literature and museums). The characteristics of the species considered for Red Listing and available scientific knowledge will dictate which approaches are the most suitable for application. Whether the manager should conduct any of the methods described here depends on the location, how much scientific knowledge is available and if it is possible to interview the population. If geographic distribution of the species is the main goal, and if sampling the species is easy, collection should be the preferred method.

5.2 Geographic distribution of Tivela mactroides in the Northern Coast of São Paulo

The methods employed to identification the distribution of Tivela mactroides helped to create a more complete scenario of the T. mactroides in the Northern Coast. A benefit derived from such methods is the ability to understand and incorporate situations that happened in the past - as the case of Saco da Ribeira, where the possible disappearance of $T$. mactroides may have been undocumented.

Even though only 20 papers were found, they should offer good certainty, as the species was taxonomically identified. Some of the papers, as Narchi (1973), are older than what we established as an old records (before 1998), similarly for museum 
records and collections. Old records of $T$. mactroides in a given beach can be considered an indicator of presence of the species and of an adequate environment, but the beach may have changed over time: in all the beaches with SHS rank 1 or 2 that had records, those records were older than 1998.

Collection records were by far the most abundant source on the occurrence of this species, especially online databases, retrieving large numbers of records. Through GBIF and speciesLink, we had access to the records of several museums at once. However, the sources used to compile the beaches with $T$. mactroides were collected by different methods, which may bring comparisons between methods that are not comparable. Some of them were obtained by digging, while others may have only collected shells on the sand, like the ones from the Tarasconi collection. Given that $T$. mactroides may also live below the intertidal zone (DENADAI; AMARAL; TURRA, 2005), some of the shells may come from locations were the exposed beach is inhospitable to the clams, and thus unable to complete the migration to the intertidal zone (DENADAl; AMARAL; TURRA, 2005), as Massaguaçu Beach. This may cause noise in the SHS and give the appearance that T. mactroides is occupying the intertidal zone in beaches it is not.

The data obtained from different databases, museums and even scientific literature may be redundant, as scientists may publish their research and deposit specimens in museums; also, different databases may have the same sources. This overlap among different data repositories and museums, with many records possibly coming from the same surveys, means the 629 total number may be lower. Judging by the metadata and coordinates, the entries are not the same, but they may have come from the same project or research project, possible linked to Amaral et al. (2003) and Project Berbigão (2013) - OBIS e ZUEC-BIV entries have these characteristics. Nevertheless, the apparent repetition/clustering did not interfere in our interpretation of the data on any given beach.

The Simplified Habitat Suitability modeling was a tool to estimate the potential number of locations for T. mactroides in the Northern Coast of São Paulo, as it indicated the likely condition of the beaches of the region. However, there were problems with the quality of the data for SHS. There was no data for 37 beaches, and for others, the information available was imprecise, as in the case of beach exposure. The biggest obstacle to this step was finding information for the shorter/more distant beaches. MAREM was used for every beach for consistency, while the other sources were used to contextualize and refine the existing data (ANNEX 1). However, some beaches perhaps would have been better described by other sources, such as Guaecá (SOUZA, 1997), but including them would create an additional source of variation. On 
the other hand, geological information is also less readily available for inaccessible beaches, making it harder to estimate their suitability for $T$. mactroides. This highlights the necessity for broad assessments to characterize beaches features to his purpose, including the ones accessible only on foot or by boat.

There is also a lack of good correlation between $T$. mactroides and beach characteristics. The information from MAREM was possibly to be of low quality and that impacted the SHS. Ideally, the SHS should be based on accurate sources, but we did not find sources for a sufficient number of beaches. Considering that the percentage of beaches with records and/or evidences only approaches $50 \%$ at SHS rank 5 , if the methods described in this work were to be applied in other situations, this could be the minimum rank to investigate beaches. An advantage of the system employed is that it is similar to classification for a SAO chart, meaning that SHS could be created for any beach classified for a SAO Chart (BRASIL, 2008).

The SHS modelling method with categorical values, based on known characteristics of the beaches was very practical and ground on previous scientific knowledge. Nevertheless, the values assigned to each feature could have weighted according the importance of the evaluated characteristics for the presence of $T$. mactroides, i.e. the highest value for slope could have been higher then the highest values of other characteristics (DENADAI; AMARAL; TURRA, 2005). Such measure would emphasize the characteristics with higher correlation with T. mactroides.

The binary system for beach exposure adapted from MAREM was an approximation to describe the real beach conditions - ideally, a system with several categories should have been employed. The temporal changes in beach state may have impacted the effectiveness of SHS, as the beaches in the São Sebastião Channel change their states with the tides, according to Souza (1997). Therefore, they may show suitable characteristics or not depending on the tide, which may explain the number of beaches in São Sebastião Channel with relative low SHS rank that had records/evidence of $T$. mactroides. There is seasonal change in beach characteristics too, as the main wave direction is from the east, followed by the waves from south, which are less prone to deflection by São Sebastião Island (YOKOYAMA; SIEGLE, 2013) and, since these waves are dominant during fall, some beaches become more dynamic during this season, depending on the orientation of the coast (TESSLER et al., 2006).

Interviews with experts were valuable methods in describing the distribution of T. mactroides, as they described five new beaches that had not appeared in previous steps, which can be considered a good number for only eight interviews. However, the pool of possible interviewees is limited, constraining the number of opinions that can be 
used. Another advantage is that the scientific name can be used in the interview, decreasing confusion.

The interviews with community members added thirteen beaches from the 28 locations cited by interviewees. The large pool of potential interviewees increased the geographical reach, allowing the observation of more parts of coast. However, the distribution of potential interviewees was uneven through the coast: it was very difficult to find persons to interview in the south of São Sebastião. This is a region where tourism has had an intense impact, displacing the caiçaras and interfering with the transmission of knowledge (RESSUREIÇÃO, 2002, p. 218). Despite our efforts to interview persons in the southern part of São Sebastião, it was very difficult to find persons both within the appropriate profile and willing to be interviewed. The very few informants in this region tended to point to beaches farther north as places with $T$. mactroides.

In addition to the twelve communities planned for the interviews, we interviewed persons in seven other locations. It was not possible to interview anyone in two communities: Enseada and Barra Velha, as people did not want to participate. There was disinterest in participating, as people fear being identified (at Camaroeiro) and complain that nothing ever changes for the fisherman (at Portinho, São Francisco and Maranduba). As Abreu, Domit and Zappes (2017) argued "most of the research results will never became part of the community, even if they are otherwise accepted" - which may discourage participation. This resulted in map of cited locations that are not evenly distribution through the coast, with very few answers in southern São Sebastião.

Some people, knowledgeable about beach shellfish, only named $T$. mactroides, "conchinha" - a generic term. On the other hand, $58,3 \%$ of the 48 original interviewees could not distinguish Anomalocardia brasiliana and Tivela mactroides; it seems to depend on the locality where the interviewee is from: different locations on the coast seemed to have different rates of people that tell them apart. Since it is not possible to use scientific names during the interviews with community members, confusion with popular names may interfere. Nevertheless, it might be an effect of the way the questions were made or bias from the interview (YANG, 2010). As the poll of possible interviewees is larger than of those of experts, the confusion with other animals may be diluted in the total universe of interviews.

It seems that some people conflate several types of shells into the same group, even though they are very knowledgeable about it. For example: a fisherman in Ilhabela initially told us that there were many "types" of shellfish before the interview started, only to say that $A$. brasiliana and $T$. mactroides were the same thing during the interview. Another interviewee, in Caraguatatuba, explained that the caiçaras 
categorize shellfish by the methods employed in harvesting them and the meat inside. In their words:

"For the caicara, what matters is what is inside here"

Some interviewees who conflated Anomalocardia brasiliana and T. mactroides (as explained in chapter 3.1.4) were keen observers of their region, as Abreu, Domit and Zappes (2017) have put it, a "member observes and experiences the surrounding environment and thus becomes an evaluator of environmental issues, as knowledge of ecosystem dynamics and structures is required to ensure their livelihood."

The call for interviewees via social media, as described in step 3.1.5, was successful because it generated an interview. However, the screening process (ANNEX 5) was unnecessary, as only ten people answered the questions and, of those, four answered them correctly and only one was actually interviewed.

Of the citizen science participation, $17(32,2 \%)$ of the submissions pertained to Caraguatatuba Bay, but it is worth noting it is the most populous of the municipality and possibly the easiest to spot the bivalve. The quality of the photos and compliance with instructions was very variable, as shown by the difference between "Adequate Submissions" and "Total submissions" and "Other Clues" in Table 3.

Comparing the number of followers in each platform and the number of submissions that followed the guidelines (Table 3), the feedback was proportionately bigger in Instagram. This may be because Instagram is already based on imagesharing. The publications returned more engagement with Instagram, considering that it had fewer followers than Facebook, (Table 3). Thus, the effort was intensified in Instagram, according to the practice described by West and Pateman (2016): "Project organizers should, therefore, incorporate research to understand changing motivations into the design of projects and use results to refine projects [...]".

All photographs were identified, thus only counting T. mactroides. However, this simple method of observing joined shells may have a drawback that was not originally foreseen: it is possible to mistake T. mactroides and Tivela ventricosa (Gray, 1838), particularly small shells. T. ventricosa lives in the infralittoral, up to thirty meters deep, and has similar morphologic features to T. mactroides (NARCHI; DARIO, 2002). The easiest ways to tell them apart are the size of the mature individual (as T. ventricosa grows up to 7,9 cm) and the dentition (NARCHI; DARIO, 2002). Other contextual clues and some color patterns on the shells could also be used, but those are less reliable.

A set of improvements can be suggested from this experience:

- The project should have engaged in citizen science through social media earlier, as more followers resulted in larger feedback. 
- A size reference in the pictures would be informative, as to estimate if the specimens are young (and may have come from the infralittoral), mature, or too large to be $T$. mactroides. This could be achieved by asking the participants to have an object of a known size in the picture.

- A description of the environment in which the valves were found would help other participants be aware of where they should be taking photos.

- An official Whatsapp number should have been set up, as this is a popular contact method, and there were submissions through this method. As a caiçara put it "WhatsApp helps a lot".

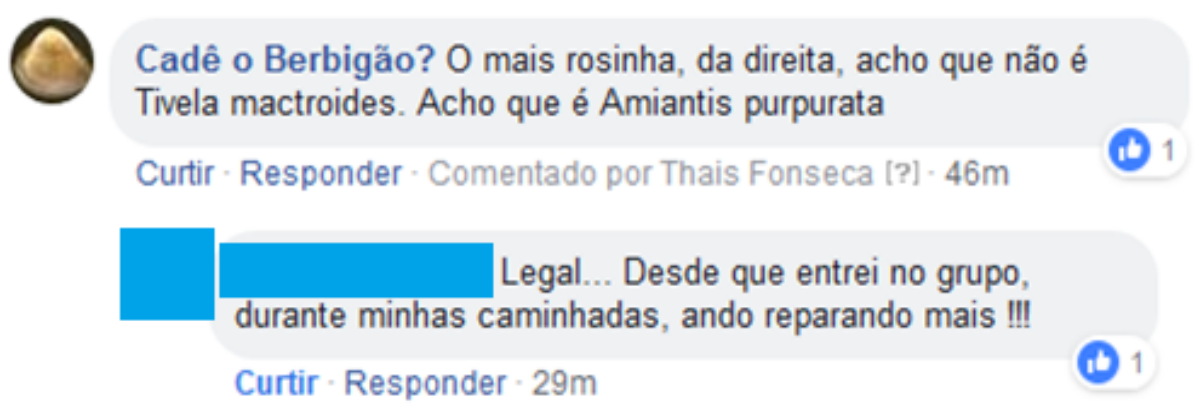

Figure 13: Interaction with one follower on Facebook, showing that the participant started to pay more attention at beach fauna.

Meanwhile, there is a lot space for expansion of citizen science projects, as most of the existing projects focuses in mixed taxa and takes place in the northern hemisphere (CHANDLER et al., 2017). There are many novel methods that have applied in conservation efforts, such as "Think for Tigers", a project that crowd-sourced ideas for tiger monitoring (CAN et al., 2017), therefore, the strategy employed in this work may be applicable to other species, localities and cases - particularly those of species that are easily spotted or are consumed by the population.

The shell observation method worked except for exceptional high tides and erosive events, as shells were found in five of the nine beaches assigned for shell observation. It is possible that there is $T$. mactroides in these four beaches and it went undetected by this method. The biggest challenge was found where shells were regularly removed by beach cleaning, such as Almada and Tenório. Another confounding factor is that the clam usually occupies the face of the beach in its adult phase, and juveniles prefer the submerged area (DENADAI; AMARAL; TURRA, 2005; information for Caraguatatuba Bay), meaning that smaller shells may have come from submerged parts of the coast. The beaches in which shells were not found (Almada; Tenório; Centro (São Sebastião) and Porto Grande) seemed to have characteristics 
less adequate than expected. This might be a result of the natural beach variability (SOUZA, 1997) and/or incomplete or incorrect sources (e.g. MAREM).

The results of the shell observation and interviews with community complement each other, as answers of the interviews gradually added beaches originally scheduled for the shell observation. However, contacts (who did not agree to be interviewed) said that there was not T. mactroides in the southern coast of São Sebastião, while a large number of shells was found at Barra do Sahy, Juquehy, and especially Boracéia, for the last one had large shells, indicating older animals that might live at the intertidal.

Given the number of beaches with records and evidence of presence of $T$. mactroides, and the number of beaches in each rank, it be expected that about more 30 beaches could be also housing T. mactroides, as shown in Figure 14. The number of potential beaches with $T$. mactroides was calculated by multiplying the number of beaches without records or evidence in each SHS rank by the fraction of the beaches with records/evidence in each SHS rank. Most of them are class 4 SHS (Figure 14).

The Beach visit and Citizen Science methods allowed a faster evaluation than by traditional sampling, which uses excavation. For a complete comparison of advantages and disadvantages methods employed for assessing the geographic distribution of T. mactroides, see Table 6.

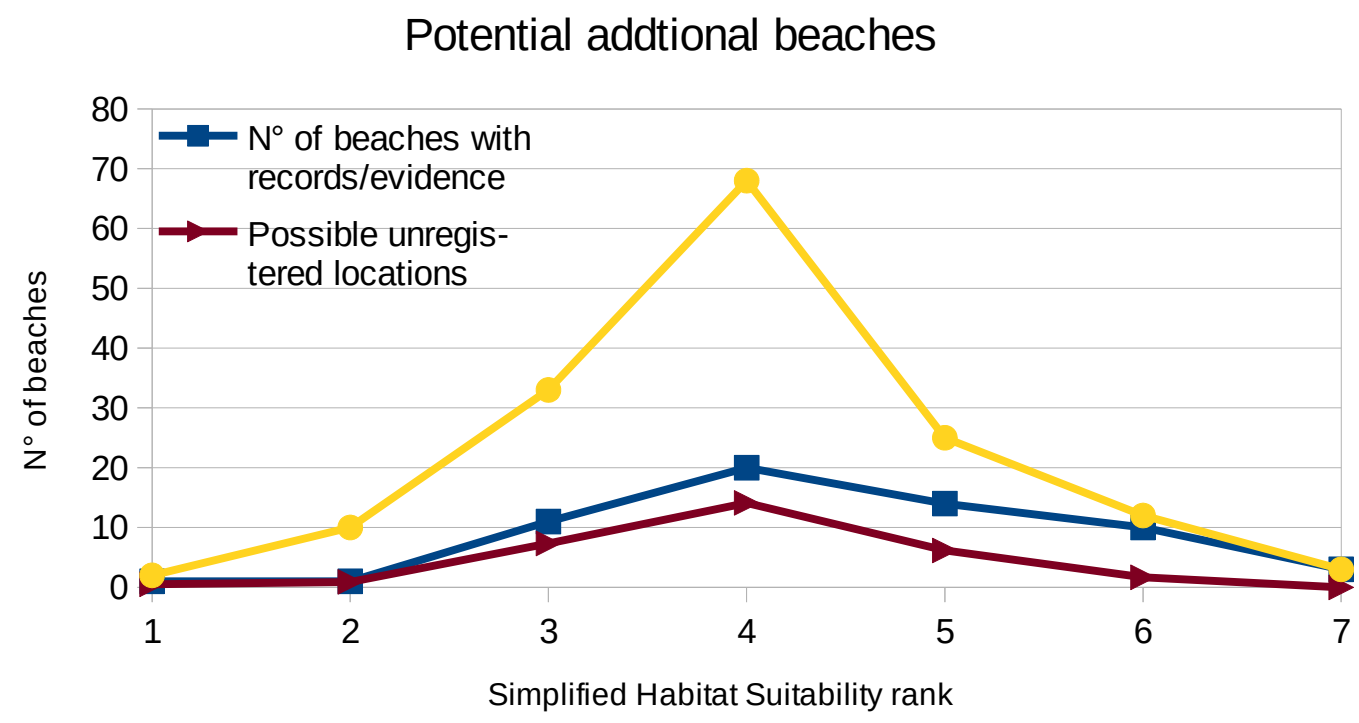

Figure 14: Graph showing: (square) the number of beaches with registers/evidence of Tivela mactroides by Simplified Habitat Suitability (SHS) rank; (triangle) number of beaches where T. mactroides might occur but no records/evidence were found; (circle) the number of beaches in that SHS rank.

As Figure 10 shows, the largest contribution came from collections and museums, followed by community interviews, emphasizing the power of interviews, since they recovered 9 new occurrences in less than a year, with a relatively small 
number of interviewees. Citizen Science may have recovered a small number of beaches (5 new locations), on the other hand, it was relatively inexpensive to put in practice and created connections that were later exploited for interviews and tips.

From all the beaches in which T. mactroides has been identified, only one of them (Bonete - Ilhabela) was inaccessible by car. Some inaccessible locations had adequate characteristics, ranking 5 or above in the SHS model; therefore, it is reasonable to assume that some of them have $T$. mactroides, and highlight the need for scientific surveys in inaccessible beaches.

Table 6: Comparison of the perceived advantages and disadvantages of the methods employed for assessing the locations with T. mactroides in the Northern Coast of São Paulo.

\begin{tabular}{|c|c|c|}
\hline Method & Advantages & Disadvantages \\
\hline \multirow{2}{*}{$\begin{array}{l}\text { Literature } \\
\text { review }\end{array}$} & $\begin{array}{l}\text { May offer other information } \\
\text { about species; }\end{array}$ & \multirow[b]{2}{*}{ Few studies exist. } \\
\hline & Professionally identified. & \\
\hline \multirow[b]{2}{*}{ Museums } & $\begin{array}{l}\text { Specimens classified by } \\
\text { professionals; }\end{array}$ & Several collection methods; \\
\hline & Long time span. & Some poorly cataloged entries. \\
\hline \multirow[b]{2}{*}{$\begin{array}{l}\text { Interview with } \\
\text { experts }\end{array}$} & Relatively quick; & $\begin{array}{l}\text { Limited number of possible } \\
\text { interviewees; }\end{array}$ \\
\hline & $\begin{array}{l}\text { Questions can be very technical } \\
\text { and specific. }\end{array}$ & $\begin{array}{l}\text { People may misremember beach } \\
\text { names or dates. }\end{array}$ \\
\hline $\begin{array}{l}\text { Interview with } \\
\text { community }\end{array}$ & $\begin{array}{l}\text { Relatively quick; } \\
\text { Constant presence of the } \\
\text { interviewee in the region; }\end{array}$ & $\begin{array}{l}\text { People may misremember } \\
\text { species, beach names or dates; } \\
\text { Niche subject. }\end{array}$ \\
\hline $\begin{array}{l}\text { Citizen Science } \\
\text { (Web) }\end{array}$ & $\begin{array}{l}\text { Relatively quick; } \\
\text { Submissions may be verified by } \\
\text { the researcher; } \\
\text { Outreach opportunity. }\end{array}$ & $\begin{array}{l}\text { May not foster connection with } \\
\text { the region; } \\
\text { Relies on the reach of the chosen } \\
\text { medium; } \\
\text { Confusion with } T \text {. ventricosa. }\end{array}$ \\
\hline $\begin{array}{c}\text { Shell } \\
\text { Observation }\end{array}$ & Relatively simple; & $\begin{array}{l}\text { May not detect T. mactroides } \\
\text { even if it is present; } \\
\text { Limited by the quality of the data } \\
\text { used to make the SHS model. }\end{array}$ \\
\hline
\end{tabular}

5.3 Application of the stepped approach in the temporal trends in the size of populations (abundance) in applications for other species

Interview answers cannot be taken for face value, and this is particularly relevant in the case of temporal trends, as it requires that the interviewee remembers several items (beach names, first time T. mactroides was seen, last time it was seen) 
correctly. In one example, one of the experts said that T. mactroides was not present in Caraguatatuba bay, which contradicts all other evidence.

It is regarding the past that the interviews are particularly useful, indicating processes and trends that were missed by previous research. Ideally, these trends would have be to be validated by capture methods; however, this is often impossible, since for many species, no monitoring existed in the desired areas, in the necessary time-frame. The trends can be base for future research, nevertheless, and guide some decision making and future scientific efforts.

5.4 Temporal trends in the size of populations (abundance) of Tivela mactroides on the Northern Coast of São Paulo state

The results found by the methods applied here were an attempt to reach a tentative trend for the population size trends of Tivela mactroides (Figure 5). The combined results of the three steps (Literature review, Interviews with experts and community) reached an overall decrease in populations of the beaches. Some beaches escape this picture, Mococa and Cocanha, where the scenario is considered stable by interviewees.

The use of literature review has allowed us to understand the state of knowledge for the Northern Coast of São Paulo state. The only long-term study found revealed population oscillation in Caraguatatuba Bay (TURRA et al., 2016b), with periodic mass mortalities. This could configure Extreme Fluctuations, one of the concepts in which IUCN bases its Red Lists, but no long term decrease in population size was found the studies (TURRA et al., 2016b). The small number of ecological studies on T. mactroides for other parts of the Northern Coast of São Paulo state highlights the necessity of more studies in the region. The body size of individuals in clams can be a predictor of ecosystem functioning (NORKKO et al., 2013), which can be concerning if $T$. mactroides has decreased in size, as two experts and a community told us.

In some ways, the interview is like a window through time, offering a perspective of the past, even if without the possibility of final validation. The perspective offered by interviewees tended to include more the surroundings. This may be a consequence of the longer period of time the locals spend in the region, compared to the researcher, as Oliveira, Santos e Turra (2018) found for the Araça Bay the perception of value, and of the problems of the region, depends on the personal proximity to the environment. The negative trend may be a bias inherent to the method (YOUNG et al., 2018), but both experts and community members agreed in their 
perceptions: the answers likely indicate that it became harder to see $T$. mactroides on some of the locations. Experts focused on the time-frame they were working in the region, and tended to have less information about the clam for the years since, as they are subject to biases and memory flaws (YOUNG et al., 2018), and alone, this could be a very important source of error for Red Lists.

Saco da Ribeira, a narrow cove in Ubatuba, had one record of Tivela mactroides in 1968. Interviewees reported that the construction of piers and marinas after the 1970's severely restricted the beach area and narrowed the sand strip, to the point that T. mactroides was no longer seen after the 1980's. As one person said "The beach is over, it is already lost". This is a case of possible local disappearance, as extinction is more probable for singular locations (CADDY; DEFEO, 2003).

The advantages and disadvantages of employing Interviews with experts and with Community for assessing temporal trends in the size of populations of $T$. mactroides were similar to what was described in the previous chapter and can be seen in Table 7.

Table 7: Comparison of the perceived advantages and disadvantages of the methods employed for assessing the temporal population and the threats to trends T. mactroides in the Northern Coast of São Paulo.

\begin{tabular}{|c|l|l|}
\hline \multicolumn{1}{|c|}{ Method } & \multicolumn{1}{|c|}{ Advantages } & \multicolumn{1}{c|}{ Disadvantages } \\
\hline Literature review & $\begin{array}{l}\text { Relatively fast; } \\
\text { Scientifically measured } \\
\text { threats; } \\
\text { Scientifically sound trends. }\end{array}$ & Small number of studies; \\
\hline Interview with experts & Relatively quick; & $\begin{array}{l}\text { Experts may have distanced } \\
\text { themselves from the region; } \\
\text { Questions can be technical } \\
\text { and specific; } \\
\text { Accessing past events. } \\
\text { interviewees; }\end{array}$ \\
\hline Interview with community \\
& $\begin{array}{l}\text { People may misremember } \\
\text { interviewee in the region; } \\
\text { beach names, dates, details. }\end{array}$ \\
\hline & $\begin{array}{l}\text { Accessing past events. } \\
\text { about the coast. }\end{array}$ & $\begin{array}{l}\text { People may misremember } \\
\text { beach names, dates, details }\end{array}$ \\
\hline
\end{tabular}

5.5 Application of the stepped approach for possible threats to populations in general and applications for other species

The procedure for identifying threats for a species depends on how much 
scientific and local knowledge is available. For well researched species, interviews with the population and experts may not be as necessary. As discussed before, the threats included thorough the interviews came from the perception of the people approached, which comes with several biases. They are preferable from no information, as they indicate threats that are at least viewed by locals and researchers. The threats indicated can also be used as indication of needed study lines. However, threats indicated by interview need at least to be contextualized by formal studies, because of said biases.

5.6 Possible threats to clam populations on the Northern Coast of São Paulo state

Of the threats found, contamination caused by pollution appeared in the three methods employed, indicating a there is a dominance of this threat. The local's perspective may deal more with problems that they see affecting the coast, and less concerned with the species itself. For a comparison among the methods employed (literature review; Interviews with experts and community), see Table 7.

As there are a variety of possible threats, the information was collected from main assessments in the region for each threat type. For some specific beaches that presented unique situations, literature was retrieved for that threat. Not all threats were readily available in literature sources, so indirect indicators of threats were used, such as beach quality reports Companhia Ambiental do Estado de São Paulo (CETESB), which were used to indicate water contamination in the Northern Coast of São Paulo.

CETESB $(1989 ; 2018)$ water quality reports show that since 1988, when the reports started to be released, the percentage of sampling points with improper water quality $50 \%$ of the time has oscillated over the years. However, the location of some sampling points has changed over time, with some points (as Saco da Ribeira) being dropped while new ones were added.

Secretaria de Saneamento e Ambiente (SMA) reports that, in 2017, the percentage of the population with access to a sewage collection system was around $39 \%$ in Ubatuba, $75 \%$ in Caraguatatuba, $41 \%$ in São Sebastião, and $35 \%$ in Ilhabela (SÃO PAULO, 2017b). This is an improvement compared to $8 \%$ of the population of Ubatuba, $10 \%$ of Caraguaguatuba and $2 \%$ of Ilhabela, in 1990, but a decrease in São Sebastião, from $50 \%$ of the population, in the same year (COMPANHIA AMBIENTAL DO ESTADO DE SÃO PAULO, 1991). Comparing maps in Figure 11 and 12, it can be seen that beaches (Mococa, Cocanha) where the scenario has improved in the past (particularly with waste water treatment) may have better perceived future scenarios. 
However, in Caraguatatuba Bay, closer to Porto Novo and Enseada, the sewage situation was perceived to be worsening, which was a drawback from computing these beaches together.

Rivers were described as a vector of pollution, almost as a threat by themselves, five times by persons who distinguished $T$. mactroides from Anomalocardia brasiliana. They are perceived as carriers of sewage, litter, and "dirt". The emphasis given to pollution by community may not be directly linked to $T$. mactroides, but to the extent waste water contamination impacts their lives negatively, through contamination of recreational waters (WYN-JONES et al., 2011; COMPANHIA AMBIENTAL DO ESTADO DE SÃO PAULO, 2018) and seafood contamination (POTASMAN; PAZ; ODEH, 2002; DIEGO et al., 2013).

Ubatuba Bay is the nearest beach to Ubatuba's city center and is a heavily urbanized area in Ubatuba (OBSERVATÓRIO LITORAL SUSTENTÁVEL, 2012). On its southern side, it receives the waters from Acaraú river, and in its northern, Grande river. Near the mouth of Acaraú River, there is a pier, while most of the beach is backed by a seawall; in some points there is no foredune. Both this beach and Acaraú River have problems with water quality, as shown in the water quality indexes published by CETESB (2018) and Instituto Costa Brasilis (2017).

The beach is used as an informal shipyard, inconveniencing some other beach users, and this activity was pointed as a threat to T. mactroides. The interviewees worried that the paints, oils, and other products used in boat maintenance could fall into the beach sand and water, therefore this threat was classified as "Other pollutants". The sewage treatment plan was often accused to be a source of pollution. The results show residents are more present observers, noticing the presence of specific chemicals - a paper by Rocha, Pereira and Malagrino (1983) describes how detergents damage the siphons and muscles of T. mactroides.

Even with three community members citing litter as a threat, there are few systematic reports on the amounts of litter found in the Northern Coast of São Paulo. There are few systematic reports on the amounts of litter found in beaches in the Northern Coast of São Paulo; however, the report released by the Instituto Argonauta shows that some beaches (Itaguá, Palmira. Carguatatuba (INSTITUTO ARGONAUTA, 2018)) can reach heavily polluted days (using the methodology described by Earll et al. (2000)). The Report on Environmental Quality published by SMA describes the management of solid waste as "inefficient" in Ubatuba and "median" in Caraguatatuba and Ilhabela (SÃO PAULO, 2017b).

The number of experts and community members that have cited Oil spill as threat to T. mactroides is accordance as the region is one of the most exposed to oil 
spills in South and Southwest regions of Brazil (TOMMASI, 1994). Some of the beaches are more exposed to oil hazards, as Saco da Ribeira. because of the two floating oil stations found there, high number of boats and low hidrodynamics (ROCHA, 2008). There is evidence that oil spills, particularly repeated ones, may affect the functioning of enzymes in the clam of Anomalocardia brasiliana (SARDI et al., 2017). The instances when community members described small spills as threats is consistent with $75 \%$ of the oil spills between 1974 and 2000 were small accidents (POFFO; XAVIER; SERPA, 2001).

Coastal structures are almost only noticed by community. Some of the beaches that had T. mactroides in the past had seawalls built, changing the beach characteristics, as Massaguaçu beach. There, constant wave action started eroding the shore, especially after the 1990's (RIBEIRO et al., 2013), and this change in beach characteristic might explain why there is an older report of $T$. mactroides there.

Given the importance of habitat suppression as threat for T. mactroides, and the reality of climate change, any attempt of protecting the species must try to avoid further development of the coast, to deal with retracing shorelines (DEFEO et al., 2009). Costello et al. (2010) have found that habitat loss is the second most pressing threat in many parts of the Ocean. Climate change is a threat that the authorities are simply not prepared to deal, in a general sense, failing to address the causes of the vulnerabilities (MARTINS; FERREIRA, 2011).

Habitat suppression, meaning that the place in which T. mactroides lives might shrink or disappear, seems to be an important threat to this species, being related to the "Coastal Structure", "Climate Change" and "Human Occupation" concepts. Climate change is a particularly challenging threat, as it interacts and amplifies other threats, reinforcing Habitat suppression (DEFEO et al., 2009). Climate change was cited by experts four times as an important feature in how the threats will change in the future. Some of the beaches that had T. mactroides in the past had seawalls built, changing the beach characteristics, as Massaguaçu beach. There, constant wave action started eroding the shore, especially after the 1990's (RIBEIRO et al., 2013), and this change in beach characteristic might explain why there is a report of T. mactroides there. An Araca Bay resident, who did not want to be interviewed, said that there is no $T$. mactroides in the bay, but there used to be before the construction of Terminal Aquaviário de São Sebastião (TEBAR). This matches the story told about Saco da Ribeira by the 2 persons that cited this beach.

Saco da Ribeira might have already have been on the edge of the suitable habitats of the species, fitting the idea expressed by experts that beaches on the limit of the characteristics may be more vulnerable (CADDY; DEFEO, 2003). As shown by 
Lopes and Schaeffer-Novelli (1989), the grain composition changed from medium to coarse sand from the 1960's to the 1980's, while the percentage of fine grains decreased.

In one indicator for coastal structures, Zoneamento Ecológico Econômico (ZEE), the area assigned class ZM2 or above stayed similar since 2004, the previous ZEE. The distribution along the coast is irregular: according to Pincinato (2007), there are few coastal structures in the Southern Coast of São Sebastião (some marinas in Barra do Sahy), while artificial structures correspond to $21 \%$ of the coast between Guaecá and the southern beginning of Caraguatatuba Bay. Rocha (2008) have identified 4 segments of coastal structures in Ubatuba, noting that the part of the coast closer to city has several small structures (piers, ramps, seawalls).

In this scenario, a buffer zone between the front dune and the first human structures is needed, so the beach can recede keeping its profile (DEAN, 1991). However; Inouye et al. (2015) showed that urban growth is still increasing in the region, even if at slower rate than the 1990-1999 period. Data from Instituto Brasileiro de Geografia e Estatística - IBGE shows that the population has been increasing steadily since the 1950 (INSTITUTO BRASILEIRO DE GEOGRAFIA E ESTATÍSTICA, 2004).

In contrast with the interviews with experts, erosion was not mentioned directly by community members; however, climate change was described as cause of transformations (not necessarily a threat) four times. This is a disconnection between academia and community, where important issues do not get transmitted - as shown by Ghilardi-Lopes et al. (2015), in a study conducted with tourists in the Northern Coast of São Paulo.

Some sections of the coast are subject to erosion - like Caraguatatuba Bay, where spits had to be build (TESSLER; GOYA, 2005), or Massaguaçu Beach, where the foredune and the road behind it were eroded (RIBEIRO et al., 2013). An overview by Souza (2010) shows that one of the expected consequences and local impact of climate change is increased erosion in Northern Coast of São Paulo, with $22 \%$ of the beaches in Ubatuba showing high risk of erosion (SOUZA; LUNA, 2009). According to the Coastal Erosion Risk Map Update for the State of São Paulo, the beaches of Ubatumirim, Barra Seca, Itaguá, Praia Grande (Ubatuba), Fortaleza, Maranduba, Tabatinga, Massaguaçú, Caraguatatuba Bay, São Francisco, Pontal da Cruz and Perequê (Ilhabela) are under "Very High" risk of eorsion (SÃO PAULO, 2011), with receding rates of $0,25 \mathrm{~m} /$ year in Ubatumirim, 0,78 m/year in Barra Seca, 1,9 m/year in Praia Grande and 0,17 m/year in Maranduba (SOUZA; LUNA, 2009).

Sea Level Rise and Climate Change may affect the wave pattern in the next decades, which may impact beach macrofauna (MACHADO et al., 2016). It should be 
noted that erosive processes induced by cold fronts act on differently in distinct beach profiles, more slowly in dissipative beaches (ALVES; PEZZUTO, 2009), the preferred habitat for T. mactroides.

The removal of dune vegetation and "restinga" is linked to increased sand loss and beach erosion (SOUSA; SIEGLE; TESSLER, 2013), which can result in habitat loss for Tivela mactroides. Recently, there have been efforts to restore the "jundu" vegetation in beaches of the Northern Coast of São Paulo state (PREFEITURA MUNICIPAL DE CARAGUATATUBA, 2018). Such actions may have raised awareness in the one community member that pointed deforestation as threat.

Compaction and crushing by trampling and vehicles was indicated as a threat, either for beaches where cars use it or heavy equipment is used to clean the beach. This consistent with the current uses of the beaches in parts of the Northern Coast of São Paulo, with beach cleaning in Caraguatuba Bay. Both trampling and vehicle usage can impact beach macrofauna (SHEPPARD; PITT; SCHLACHER, 2009; REYESMARTÍNEZ et al., 2015)

For both specialists and residents, there is concern about real estate developments and human occupation, which is symptomatic considering the history of occupation of the region by outsiders and real estate speculation. The economical, cultural and demographic changes brought by tourism are intense, and a fundamental driver of change, particularly in the most visited beaches, as Maranduba, Caraguatatuba Bay and Itaguá, have changed the practices in these localities (TEIXEIRA; IWAMA, 2017). The tendency of this threat is to continue into the future, judging not only by interviewee perception, but as the population is expected to continue growing (INOUYE et al., 2015; SÃO PAULO, 2017).

For capture, the number reported by Instituto de Pesca (IP) for "berbigão" includes A. brasiliana (SÃO PAULO, 2019), and the only capture figure (30 tons/year) found is the study by Turra et al. (2016b). As a consequence, there are no capture projections or estimates for the future. Our studies pointed that three experts and five community members said that capture might put an additional threat to T. mactroides. Caraguatatuba Bay was where capture had the biggest presence. This was the only place where we found and interviewed persons who collected T. mactroides for a living. However, other threats are very relevant in the Bay, most notably waste water.

Ubatuba Bay is the nearest beach to Ubatuba's city center and is a heavily urbanized area in Ubatuba (OBSERVATÓRIO LITORAL SUSTENTÁVEL, 2012). On its southern side, it receives the waters from Acaraú river, and in its northern, Grande river. Near the mouth of Acaraú River, there is a pier, while most of the beach is backed by a seawall; in some points there is no foredune. Both this beach and Acaraú River 
have problems with water quality, as shown in the water quality indexes published by CETESB (2018) and Instituto Costa Brasilis (2017). The beach is used as an informal shipyard, inconveniencing some other beach users, and this activity was pointed as a threat to T. mactroides, falling on what was classified as "Other threats".

5.7 Tivela mactroides in the List of Endangered Species of the State of São Paulo and applications for other species

The literature review, the consultation to data repositories and collections, interviews with experts and community, citizen science approach and shell observation were able to retrieve 59 locations, more than it would be registered by literature, data repositories/museums and expert judgment alone, the customary ways Red Lists are conceived. Meanwhile, the literature review and interviews with experts and community were able to shed light into past and future population trends, revealing a perceived trend of decrease in 24 out of 59 beaches.

At the same time, the interviews revealed possible threats to $T$. mactroides that could jeopardize the maintenance of these populations locally. Waste water, oil spills and other pollutants were cited six times by experts and ten times by community members as threats for the whole coast, reinforcing their role in the Northern Coast of São Paulo state. Such alternative methods can be highly relevant in revealing past population size trends and describing possible threats and future population scenarios, especially in a situation with insufficient published studies in literature.

Given the multiple threats to Tivela mactroides reported in this work, understanding the cumulative impacts of multiple stressors in a scenario of habitat suppression is fundamental (SCHLACHER et al., 2007). Scarce data makes this situation even more complex, as categorization with little data becomes even more subjective (EUROPEAN UNION, 2018). Additionally, this work highlighted the necessity of formal data collection, particularly in areas that are not road accessible. Even with the success of new approaches, this study can be seen as an indicator of the importance of the more traditional methods of beach sampling: even if not as a project on its own, at least as validation of data acquired in other ways.

Even if the Census of the Ocean, by Costello et al. (2010), puts over-fishing as the greatest threat to marine biodiversity, capture, at least directly, is not perceived as the dominant threat to T. mactroides, even by experts. Ideally, the inclusion on a Red List should not be sole factor in prohibiting the capture of an organism (POSSINGHAM et al., 2002), increasing the conflicts between conservation entities and the general population (REDPATH et al., 2013). However, prohibition is the consequence when $T$. 
mactroides is put in the List of Endangered Species of the State of São Paulo. This indicates that either the law should have other consequences or the organism should not be on the list. Farrier, Whelan, and Mooney (2007) discussed ways of using IUCN categorization in conservation actions, accounting for the economic aspects the species may have, and suggest that the listing should not be automatically linked to the ban on use.

This is shown in the Figure 11, the interviews showed that the most commonly perceived threats are linked to pollution. Capture may not be negligible, because it was mentioned 8 times by experts and community members, but may be a manageable resource. Thus, considering that the most notable consequence of the inclusion of a species in the List of Threatened Species of the State of São Paulo is that the species becomes protected from capture by law, the inclusion on the list might not offer adequate protection for T. mactroides.

The current study encompasses a fraction of the area covered by the List of Threatened Species of the State of São Paulo, therefore the current status of $T$. mactroides in the entire coast cannot be assessed here. Nevertheless, the perceived decrease population size and the threats registered for the study area are signs that the current situation may fulfill IUCN Criteria A and E. Under a Precautionary Principle, action in order to maintain the populations of $T$. mactroides might be necessary.

Hence, Ecosystem-Based practices could be a better alternative, where the entire beach would be managed as whole, looking at all the inputs and outputs to the system, and regulate them properly, aiming to maintain Environmental Services and beach quality (BRODZIAK; LINK, 2002). Ecosystem-Based Management and practices are characterized by "essentially reversing the order of management priorities to start with the ecosystem rather than the target species" (PIKITCH et al., 2004). For example, such system could aim to maintain good environmental quality and maintenance of ecosystem services, and the conservation of any particular species would entail more adapted action than just fishing prohibition (BRODZIAK; LINK, 2002). One example in this direction, is the IUCN List of Endangered Ecosystems, in which ecosystems deemed endangered and important are be considered as a whole in a list that aims to ensure its protection (RODRÍGUEZ et al., 2010).

This situation is especially relevant for species with economic, recreational and/ or cultural importance, once the non-reported capture of an endangered species may cause arrest without bail in Brazil (Federal Law No 9,605/1998). Any action in conservation biology should incorporate human desires and communication to be successful (JACOBSON; DUFF, 2008). In the T. mactroides case it might mean measures to prevent impacts from sewage or by-catch. Technically, the law may not 
punish persons that only capture small quantities for their subsistence, because of the "Insignificance Principle" (FERNANDES, 2012). If a law is created without the intention to be enforced, this weakens the law and devalues its importance in situations where it could be useful. In the case of Red List, if the expectations are that they will not be enforced, it cannot be employed as tool in a conservation strategy. A possible compromise is similar to the case of Ucides cordatus: when the present-day abundance of the species was attested, the species was removed from the list and a government provision was created, allowing the capture of the species by certain groups of people (SÃO PAULO, 2015b). Such action could avoid conflict with communities in the Northern Coast of São Paulo. 


\section{CONCLUSION}

The use of progressive methods, even with gaps and frailties, has allowed to the creation of a more complete and comprehensive panorama on the current situation of Tivela mactroides in the Northern Coast of the State of São Paulo, concerning its local (1) geographical distribution, (2) temporal trends in population size and (3) threats to its continued existence. These three points cover concepts defined by the International Union for Conservation of Nature (IUCN) of Population, Location and Reduction, relevant for its conservation and to support the elaboration of the Lists of Endangered species.

The combined results of the stepped approach have shown number of locations with occurrence of $T$. mactroides was larger than what would be expected by simply using traditional sources of information. It was also found that the populations of $T$. mactroides in Caraguatatuba Bay, the only time series available in the region, did not have signs of decrease, although the interviewees perceived a decline in most beaches. Additionally, most of the threats described by experts and community are pollution related (waste water, oil, other pollutants), and linked to erosion in the case of experts, which makes sense in the context of the Northern Coast of the State of São Paulo.

This shows that alternative methods can be applied for Red List purposes, with some caveats. Proper scientific and technical works are fundamental, but the approaches employed here can be applied to alleviate knowledge gaps. Not all steps need to be employed at once, and which ones are most advantageous depend on the species, the region and the time and resources available.

In spite of the study region being smaller than the area covered by the List of Endangered Species of the State of São Paulo and the frailties of stepped approach employed here, the variety of threats identified by this study show that the inclusion in the List of Endangered Species might not be sufficient to properly protect $T$. mactroides, at least not by itself. Moreover, the use of $T$. mactroides in the caiçara culture may foster conflicts with the local population, which runs counter both conservation and cultural interests. Similar situation can happen to other species, showing the benefits of identifying the existing and possible threats.

In this context, it is highlighted the necessity of an Ecosystem Based approach, that would consider the coast as whole, taking actions to protect coastal species beyond capture, considering both human and ecological aspects, and incorporating non-traditional knowledge and exercising the Precautionary Principle. The limitations of List of Endangered Species of the State of São Paulo exemplify the necessity of 
studies and management mechanisms that go beyond the focus on capture. Alternatively, measures that allow for the capture by artisan fisherman but maintain the species in question protected, thus avoiding conflict with local communities and granting protection, could be a possibility.

This study reinforces that further studies and better knowledge on the impacts of capture of listed species and of its prohibition in traditional cultures are fundamental in parallel with the categorization in a Red List. The conclusions for this work show the real possibility of using alternative methods to raise information that could be used in decision making in marine conservation. 


\section{REFERENCES}

ABREU, J, S.; DOMIT, C.; ZAPPES, C. A.. Is there dialogue between researchers and traditional community members? The importance of integration between traditional knowledge and scientific knowledge to coastal management. Ocean \& Coastal Management, [s.I.], v. 141, p.10-19, jun. 2017. Elsevier BV. http://dx.doi.org/10.1016/j.ocecoaman.2017.03.003.

ACOSTA, V.; LODEIROS, C.. Metales pesados en la almeja Tivela mactroides Born, 1778 (Bivalvia: Veneridae) en localidades costeras con diferentes grados de contaminación en Venezuela. Ciencias Marinas, Sucre, v. 30, n. 2, p.323-333, dez. 2014.

ALVES, E S; PEZZUTO, P. R.. Effect of cold fronts on the benthic macrofauna of exposed sandy beaches with contrasting morphodynamics. Brazilian Journal Of Oceanography, [s.I.], v. 57, n. 2, p.73-94, jun. 2009. FapUNIFESP (SciELO). http://dx.doi.org/10.1590/s1679-87592009000200001.

AMARAL, A. C. Z. et al. Intertidal Macrofauna in Brazilian Subtropical Tide-Dominated Sandy Beaches. Journal of Coastal Research. [s.I], v. 35, p.446-455. [s. ed.], abril, 2003.

AMARAL, A. C. Z.; RIZZO, A. E.; ARRUDA, E. P.. Manual de identificação dos invertebrados marinhos da região Sudeste-Sul do Brasil. São Paulo: Edusp, 2005. $287 \mathrm{p}$.

ANDRADE, L. T. A. Análise dos processos hidrodinâmicos e sedimentares da Enseada da Fortaleza, Ubatuba/São Paulo. 2002. 87 f. Dissertação (Mestrado) Curso de Oceanografia, Universidade de São Paulo, São Paulo, 2002.

ANTONELI, F. M.. Caracterização da dinâmica sedimentar atual na região d'As Ilhas, São Sebastião, litoral norte do Estado de São Paulo. 2004. 132 f. Dissertação (Mestrado) - Curso de Oceanografia Química e Geológica, Universidade de São Paulo, São Paulo, 2004.

ARRIECHE, D; PRIETO, A.. Parámetros poblacionales del guacuco Tivela mactroides (Bivalvia: Veneridae) de Playa Caicara, Estado Anzoátegui, Venezuela. Ciencias Marinas: 2006, Sucre, v. 2, n. 32, p.285-296, jun. 2006.

ARRUDA, E. P.; DOMANESCHI, O.; AMARAL, A. C. Z. Mollusc feeding guilds on sandy beaches in São Paulo State, Brazil. Mar. Biol. V. 213, p. 691-701. Abril 2003

BALKE, M. et al. Biodiversity into your hands - A call for a virtual global natural history 'metacollection'. Frontiers In Zoology, [s.I.], v. 10, n. 1, p.55-64, 2013. Springer Nature. http://dx.doi.org/10.1186/1742-9994-10-55.

BARROS, M. O.. Dinâmica e evolucao dos ambientes praiais da Fazenda do Puruba e de Itamambuca, Ubatuba, Litoral Norte do Estado de São Paulo. 1997. 64 f. Tese (Doutorado) - Curso de Oceanografia, Universidade de São Paulo, São Paulo, 1997.

BECK, J. et al. Spatial bias in the GBIF database and its effect on modeling species' geographic distributions. Ecological Informatics, [s.I.], v. 19, n. 1, p.10-15, jan. 2014. 
Elsevier BV. http://dx.doi.org/10.1016/j.ecoinf.2013.11.002.

BELUCIO, L. F.. Comunidades benticas de moluscos da zona entremares da região do Araça, São Sebastião, SP. 1995. 144 f. Dissertação (Mestrado) - Curso de Ciênicas Biológicas, Universidade Estadual de Campinas, Campinas, 1995.

BERS, A. V. et al. A Combined Approach of Benthic Mapping of Caraguatatuba Bay, Brazil, with Recommendations for Management Practices. Ocean \& Coastal Management. [s.I.], v. 213, n. 1, p. 269-274. Elsevier, out. 2013.

BLAND, L. M. et al. Assessing risks to marine ecosystems with indicators, ecosystem models and experts. Biological Conservation, [s.I.], v. 227, n. 1, p.19-28, nov. 2018. Elsevier BV. http://dx.doi.org/10.1016/j.biocon.2018.08.019.

BOCKSTAEL, E. et al. Participation in protected area management planning in coastal Brazil. Environmental Science \& Policy, [s.I.], v. 60, n. 1, p.1-10, jun. 2016. Elsevier BV. http://dx.doi.org/10.1016/j.envsci.2016.02.014

BRASIL. Decreto $n^{\circ} 8.425$, de 21 de março de 2015. Pescadoras e pescadores de subsistência que praticam a atividade de pesca com fins de consumo doméstico ou escambo sem fins de lucro. Diário Oficial da União. Brasília, DF.

BRASIL. Lei $n^{\circ} 11.959$, de 29 de junho de 2009. Dispõe sobre a Política Nacional de Desenvolvimento Sustentável da Aquicultura e da Pesca, regula as atividades pesqueiras, revoga a Lei no 7.679 , de 23 de novembro de 1988, e dispositivos do Decreto-Lei no 221, de 28 de fevereiro de 1967, e dá outras providências. Diário Oficial da União. Brasília, DF.

BRASIL. Lei $n^{\circ}$ 9.605, de 12 de fevereiro de 1998. Diário Oficial da União: Dispõe sobre as sanções penais e administrativas derivadas de condutas e atividades lesivas ao meio ambiente.

BRASIL. MINISTÉRIO DO MEIO AMBIENTE. Atlas de Sensibilidade Ambiental ao Óleo da Bacia Marítima de Santos. Brasília: Arteg Bureau de Artes, 2008. 116 p.

BRODZIAK, J.; LINK, J. S. Ecosystem-Based Fishery Management: What Is It and How Can We Do It?. Bulletin Of Marine Science, Miami, v. 70, n. 2, p.589-611, fev. 2002.

BUSCH et al. Content Analysis. Fort Collins: Colorado State University, 2012. 27 p.

CADDY, J. F.; DEFEO, O.. Enhancing or restoring the productivity of natural populations of shellfish and other marine invertebrate resources. Roma: Fao, 2003.

CAN, Ö. E. et al. Scientific crowdsourcing in wildlife research and conservation: Tigers (Panthera tigris) as a case study. Plos Biology, [s.I.], v. 15, n. 3, p.1-10, 22 mar. 2017. Public Library of Science (PLoS). http://dx.doi.org/10.1371/journal.pbio.2001001.

CAOBELLI, J. F.. Biologia e ecologia de Eutima sapinhoa (Cnidaria, Hydrozoa): uma espécie comensal de Tivela mactroides (Mollusca, Bivalvia). 2016. 70 f. Biota Neotropica. 
CARDOSO, D. G.. Variabilidade Praial nas Praias do Lázaro, Domingas Dias e Sununga, Litoral Norte de São Paulo Frente à Passagem dos Sistemas Frontais (Ubatuba, SP). 2013. Dissertação (Mestrado em Oceanografia Geológica) - Instituto Oceanográfico, Universidade de São Paulo, São Paulo, 2013. doi:10.11606/D.21.2013.tde-16122014-154727. Acesso em: 2018-01-23.

CARDOSO, P. et al. The seven impediments in invertebrate conservation and how to overcome them. Biological Conservation, [s.I.], v. 144, n. 11, p.2647-2655, nov. 2011. Elsevier BV. http://dx.doi.org/10.1016/j.biocon.2011.07.024.

CASALE, P.; TUCKER, A. D.. Caretta caretta. IUCN Red List of Threatened Species, [s.I.], v. 1, n. 1, p.1-19, 1 dez. 2015. IUCN. http://dx.doi.org/10.2305/iucn.uk.20154.rlts.t3897a83157651.en.

CHANDLER, M. et al. Contribution of citizen science towards international biodiversity monitoring. Biological Conservation, [s.I.], v. 213, p.280-294, set. 2017. Elsevier BV. http://dx.doi.org/10.1016/j.biocon.2016.09.004.

COELHO, S. C. C.. Dinâmica morfo-sedimentar da praia de Paúba, São Paulo. 2016. 56 f. TCC (Graduação) - Curso de Oceanografia, Universidade de São Paulo, São Paulo, 2016.

COLLEN, B. et al. The Tropical Biodiversity Data Gap: Addressing Disparity in Global Monitoring. Tropical Conservation Science, [s.I.], v. 1, n. 2, p.75-88, jun. 2008. SAGE Publications. http://dx.doi.org/10.1177/194008290800100202.

COMPANHIA AMBIENTAL DO ESTADO DE SÃO PAULO (São Paulo). Secretaria do Meio Ambiente. Relatório de qualidade das praias no estado de São Paulo 1988. São Paulo: CETESB, 1989.

COMPANHIA AMBIENTAL DO ESTADO DE SÃO PAULO (São Paulo). Secretaria do Meio Ambiente. Relatório de qualidade das praias no estado de São Paulo 1990. São Paulo: CETESB, 1991.

COMPANHIA AMBIENTAL DO ESTADO DE SÃO PAULO (São Paulo). Secretaria do Meio Ambiente. Relatório de qualidade das praias no estado de São Paulo 2017. São Paulo: CETESB, 2018.

CORTE, G. N.. Fauna de Fundo Não-Consolidado da Baía do Araçá, Litoral Norte de São Paulo. 2016. 95 f. Tese (doutorado). Curso de Ecologia, Universidade Estadual de Campinas, Campinas, 2013.

DEAN, R. G.. Equilibrium Beach Profiles: Characteristics and Applications. Journal Of Coastal Research, Fort Lauderdale, v. 1, n. 7, p.53-84, jan. 1991.

DEFEO, O. et al. Threats to sandy beach ecosystems: A review. Estuarine, Coastal And Shelf Science, [s.l.], v. 81, n. 1, p.1-12, jan. 2009. Elsevier BV. http://dx.doi.org/10.1016/j.ecss.2008.09.022.

DEFEO, O.; MCLACHLAN, A.. Coupling between macrofauna community structure and beach type: a deconstructive meta-analysis. Marine Ecology Progress Series, [s.I.], v. 433, p.29-41, 18 jul. 2011. Inter-Research Science Center. http://dx.doi.org/10.3354/ meps09206. 
DENADAI, M. R. et al. Assessment of contamination of the beach clam Tivela mactroides: implications for food safety of a recreational and subsistence marine resource in Caraguatatuba Bay, Brazil. International Journal Of Food Contamination, [s.I.], v. 2, n. 1, p.1-12, 26 abr. 2015. Springer Nature. http://dx.doi.org/ 10.1186/s40550-015-0012-4.

DENADAI, M. R. et al. Reproductive cycle of the trigonal clam Tivela mactroides (Bivalvia, Veneridae) in Caraguatatuba Bay, southeastern Brazil. Marine Biology Research, [s.I.], v. 11, n. 8, p.847-858, 3 jun. 2015b. Informa UK Limited. http://dx.doi.org/10.1080/17451000.2015.1024130.

DENADAI, M. R.; AMARAL, A. C. Z.; TURRA, A.. Along and across shore components of the spatial distribution of the clam Tivela mactroides (Born, 1778) (Bivalvia, Veneridae). Journal of Natural History, [s.I.], v. 39, n. 36, p.3275-3295, 22 nov. 2005. Informa UK Limited. http://dx.doi.org/10.1080/00222930500126156.

DENADAI, M. R.; AMARAL, A. C. Z.; TURRA, A.. Structure of Molluscan Assemblages in Sheltered Intertidal Unconsolidated Environments. Brazilian Archives of Biology and Technology. São Paulo, v. 48, n. 5, p. 825-839. [s. ed.], set. 2005b.

DENADAI, M.R. et al. Veneridae (Mollusca, Bivalvia) from the north coast of São Paulo State, Brazil. Biota Neotropica. Campinas, vol. 6, no. 3. [s. ed.], set. 2006.

DIEGO, A. G. Leal et al. Sanitary quality of edible bivalve mollusks in Southeastern Brazil using an UV based depuration system. Ocean \& Coastal Management, [s.I.], v. 72, p.93-100, fev. 2013. Blsevier http://dx.doi.org/10.1016/j.ocecoaman.2011.07.010.

EARLL, R. C. et al. Aquatic litter, management and prevention-the role of measurement. Journal Of Coastal Conservation, [s.I.], v. 6, n. 1, p.67-78, dez. 2000. Springer Nature. http://dx.doi.org/10.1007/bf02730470.

EDGAR, Graham J. et al. New opportunities for conservation of handfishes (Family Brachionichthyidae) and other inconspicuous and threatened marine species through citizen science. Biological Conservation, [s.I.], v. 208, p.174-182, abr. 2017. Elsevier BV. http://dx.doi.org/10.1016/j.biocon.2016.07.028.

ELLWOOD, E. R.; CRIMMINS, T. M.; MILLER-RUSHING, A. J.. Citizen science and conservation: Recommendations for a rapidly moving field. Biological Conservation, [s.I.], v. 208, p.1-4, abr. 2017. Elsevier BV. http://dx.doi.org/10.1016/j.biocon.2016.10.014.

EUROPEAN UNION. European Commision. European Commision For Environment. European Red List: Data types. 2018. Disponível em: <http://ec.europa.eu/environment/nature/conservation/species/redlist/process/data/ data_types.htm>. Acesso em: 08 mar. 2019.

FARRIER, D.; WHELAN, R.; MOONEY, C.. Threatened species listing as a trigger for conservation action. Environmental Science \& Policy, [s.I.], v. 10, n. 3, p.219-229, maio 2007. Elsevier BV. http://dx.doi.org/10.1016/j.envsci.2006.12.001.

FERNANDES, M.. STF aplica princípio da insignificância em crime ambiental. Direito Ambiental. [s. I.], p. 1-2. Ago. 2012. 
FOOD AND AGRICULTURE ORGANIZATION OF THE UNITED NATIONS. The State of World Fisheries and Aquiculture 2016: Contributing to food security and nutrition for all. Rome: [s.ed.], 2016. 200 p

FOURCADE, Y.. Comparing species distributions modelled from occurrence data and from expert-based range maps. Implication for predicting range shifts with climate change. Ecological Informatics, [s.I.], v. 36, n. 1, p.8-14, nov. 2016. Elsevier BV. http://dx.doi.org/10.1016/j.ecoinf.2016.09.002.

FUNDAÇÃO DE AMPARO À PESQUISA DO ESTADO DE SÃO PAULO. O Projeto. 2017. Disponível em: <http://splink.cria.org.br/project?criaLANG=pt>. Acesso em: 24 mar. 2017.

FUNTOWICZ, S. O.; RAVETZ, J. R.. Science for the post-normal age. Futures, [s.I.], v. 25, n. 7, p.739-755, set. 1993. Elsevier BV. http://dx.doi.org/10.1016/00163287(93)90022-।.

GARDINER, L, M.; BACHMAN, S.. The role of citizen science in a global assessment of extinction risk in palms (Arecaceae). Botanical Journal Of The Linnean Society, [s.I.], v. 182, n. 2, p.543-550, 6 abr. 2016. Oxford University Press (OUP). http://dx.doi.org/10.1111/boj.12402

GHILARDI-LOPES, N. P. et al. On the perceptions and conceptions of tourists with regard to global environmental changes and their consequences for coastal and marine environments: A case study of the northern São Paulo State coast, Brazil. Marine

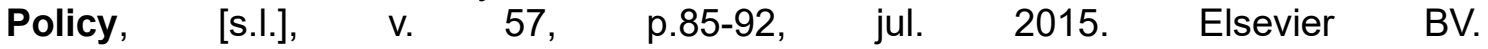
http://dx.doi.org/10.1016/j.marpol.2015.03.005.

GLOBAL BIODIVERSITY INFORMATION FACILITY. What is GBIF? Disponível em: $<$ https://www.gbif.org/>. Acesso em: 13 ago. 2018.

GRAHAM, C. et al. New developments in museum-based informatics and applications in biodiversity analysis. Trends In Ecology \& Evolution, [s.I.], v. 19, n. 9, p.497-503, set. 2004. Elsevier BV. http://dx.doi.org/10.1016/j.tree.2004.07.006.

GRAHAM, C. H.; HIJMANS, Robert J.. A comparison of methods for mapping species ranges and species richness. Global Ecology And Biogeography, [s.l.], v. 15, n. 6, p.578-587, nov. 2006. Wiley. http://dx.doi.org/10.1111/j.1466-8238.2006.00257.x.

GRANT, Maria J.; BOOTH, Andrew. A typology of reviews: an analysis of 14 review types and associated methodologies. Health Information \& Libraries Journal, [s.I.], v. 26, n. 2, p.91-108, 27 maio 2009. Wiley. http://dx.doi.org/10.1111/j.14711842.2009.00848.x.

GUBITOSO, S. et al. Estudo Geoambiental da Região Circunjacente ao Emissário Submarino de Esgotos do Araçá, São Sebastião. Revista Brasileira de Geociências, São Paulo, v. 39, n. 3, p.467-475, set. 2008.

HALPERN, B. S. et al. A Global Map of Human Impact on Marine Ecosystems. Science, [s.I.], v. 319, n. 5865, p.948-952, 15 fev. 2008. American Association for the Advancement of Science (AAAS). http://dx.doi.org/10.1126/science.1149345.

HURTADO, S. N.; GOYA, S. C. y; TESSLER, M. G.. Journal Article Evolution and Dynamic of Itamambuca Beach and Comparative Evaluation of Morphodynamic 
Studies of Beaches. Journal Of Coastal Research, S.I., v. 39, n. 1, p.568-571, nov. 2016.

ILHABELA.COM.BR. Praias. Disponível em: <https://www.ilhabela.com.br/praias>. Acesso em: 28 mar. 2019.

INOUYE, C. E. N. et al. Modelling the spatial dynamics of urban growth and land use changes in the north coast of São Paulo, Brazil. Ocean \& Coastal Management, [s.I.], v. 108, p.147-157, maio 2015.2 Elsevier BV. http://dx.doi.org/10.1016/j.ocecoaman.2014.12.016.

INSTITUTO ARGONAUTA. BOLETIM DO LIXO NAS PRAIAS DO LITORAL NORTE DE SÃO PAULO: Instituto Argonauta para Conservação Costeira e Marinha. Caraguatatuba: Sin. Ed, 2018.

INSTITUTO BRASILEIRO DE GEOGRAFIA E ESTATÍSTICA. Cidades. 2016. Disponível em: <http://cidades.ibge.gov.br/xtras/uf.php?lang=\&coduf=35\&search=saopaulo>. Acesso em: 26 mar. 2017.

INSTITUTO BRASILEIRO DE GEOGRAFIA E ESTATÍSTICA. Tendências demográficas: uma análise dos resultados da amostra do censo demográfico 2000. IBGE, [s. ed], 2004. 155 p.

INSTITUTO BRASILEIRO DO MEIO AMBIENTE E DOS RECURSOS NATURAIS RENOVÁVEIS. MAREM. 2018. Disponível em: <http://www.marem-br.com.br/>. Acesso em: 29 mar. 2019.

INSTITUTO COSTA BRASILIS (São Paulo). Boletim Rio Acaraú. 4. ed. Ubatuba: S. Ed., 2017. 4 p.

INTERNATIONAL UNION FOR CONSERVATION OF NATURE AND NATURAL RESOURCES (Switzerland). Guidelines for Application of IUCN Red List Criteria at Regional and National Levels. Gland: IUCN, 2012. 46 p. (Version 4.0).

INTERNATIONAL UNION FOR CONSERVATION OF NATURE AND NATURAL RESOURCES (Switzerland). IUCN Red List Categories and Criteria. Gland: IUCN, 2000. 38 p. (Version 3.).

INTERNATIONAL UNION FOR CONSERVATION OF NATURE AND NATURAL RESOURCES. Guidelines for Applying the Precautionary Principle to Biodiversity Conservation and Natural Resource Management. Gland: IUCN, 2007. 11 p.

INTROINI, G. O. et al. Spermatozoan ultrastructure and detection of nuclear acid phosphatase activity in spermatids of Anomalocardia brasiliana and Tivela mactroides (Bivalvia: Veneridae). The Nautilus, Sanibel, v. 123, n. 4, p.293-302, 31 mar. 2009.

ISAAC, N J. B.; POCOCK, M. J. O.. Bias and information in biological records. Biological Journal of the Linnean Society, [s.I.], v. 115, n. 3, p.522-531, 20 abr. 2015. Oxford University Press (OUP). http://dx.doi.org/10.1111/bij.12532.

JACOBSON, S. K.; DUFF, M. D.. Training Idiot Savants: The Lack of Human Dimensions in Conservation Biology. Conservation Biology, [s.I.], v. 12, n. 2, p.263267, 7 jul. 2008. Wiley. http://dx.doi.org/10.1111/j.1523-1739.1998.97235.x. 
LAURIA, V. et al. Predictive habitat suitability models to aid conservation of elasmobranch diversity in the central Mediterranean Sea. Scientific Reports, [s.I.], v. 5, n. 1, p.1-16, 14 ago. 2015. Springer Nature. http://dx.doi.org/10.1038/srep13245.

LEAL, D. A. G. et al. First report of Cryptosporidium spp. oocysts in oysters (Crassostrea rhizophorae) and cockles (Tivela mactroides) in Brazil. Journal of Water and Health. [s.I.]. v. 6, n. 4, p. 527-532. IWA Publishing, 2008.

LOPES, S. G. B. C.; SCHAEFFER-NOVELLI, Y. Bivalves e gastrópodes do Saco da Ribeira, Ubatuba - São Paulo. I. Levantamento, distribuição das espécies e características ambientais. Boletim de Zoologia, [s.l.], v. 13, n. 13, p.9-49, 8 nov. 1989. Universidade de Sao Paulo Sistema Integrado de Bibliotecas - SIBiUSP. http://dx.doi.org/10.11606/issn.2526-3358.bolzoo.1989.122696.

MACHADO, Phillipe $M$. et al. Extreme storm wave influence on sandy beach macrofauna with distinct human pressures. Marine Pollution Bulletin, [s.I.], v. 107, n. 1, p.125-135, jun. 2016. Elsevier BV. http://dx.doi.org/10.1016/j.marpolbul.2016.04.009.

MAES, D. et al. The use of opportunistic data for IUCN Red List assessments. Biological Journal of the Linnean Society, [s.I.], v. 115, n. 3, p.690-706, 9 abr. 2015. Oxford University Press (OUP). http://dx.doi.org/10.1111/bij.12530.

MAGRIN, G. O. et al. Central and South America In: Climate Change 2014: Impacts, Adaptation, and Vulnerability. Part B: Regional Aspects. Contribution of Working Group II to the Fifth Assessment Report of the Intergovernmental Panel on Climate Change. Climate Change 2014: Impacts, Adaptation, Vulnerability. Part B: Regional Aspects. Contribution of Working Group II to the Fifth Assessment Report of the Intergovernmental Panel on Climate Change, p. 1499-1566, 2014.

MARTINS, C. C.. Morfodinâmica de Praia Refletiva: Estudo de Caso na Praia da Sununga, Litoral Norte do Estado de São Paulo. 2006. 209 f. Tese (Doutorado) Curso de Oceanografia, Universidade de São Paulo, São Paulo, 2006.

MARTINS, R. D.; FERREIRA, L. C.. Governing climate change: urbanization, vulnerability and challenges for the Northern Coast of the state of São Paulo, Brazil. Sustentabilidade em Debate, Brasília, v. 2, n. 2, p.55-82, jul. 2011.

MCDOUGLE, L. M.; GREEN, I; HANDY, F. Generation green: understanding the motivations and mechanisms influencing young adults' environmental volunteering. International Journal Of Nonprofit And Voluntary Sector Marketing, [s.I.], v. 16, n. 4, p.325-341, nov. 2011. Wiley. http://dx.doi.org/10.1002/nvsm.431.

MCKINLEY, D. C. et al. Citizen science can improve conservation science, natural resource management, and environmental protection. Biological Conservation, [s.I.], v. 208, p.15-28, abr. 2017. Elsevier BV. http://dx.doi.org/10.1016/j.biocon.2016.05.015.

MCLACHLAN, A. et al. Beach clam fisheries. Oceanography and Marine Biology: An Annual Review, [s.I], v. 34, n. 1, p.163-232, dez. 1996.

MCLACHLAN, A.. Physical factors in benthic ecology: effects of changing sand particle size on beach fauna. Marine Ecology Progress Series, [s.I.], v. 131, p.205-217, 1996. Inter-Research Science Center. http://dx.doi.org/10.3354/meps131205. 
MEDEIROS, E. L.; HENRY-SILVA, G. G. Distribuição e densidade do bivalve Tivela mactroides (Born, 1778) em região estuarina tropical do semiárido do nordeste brasileiro,. , v. 27, n. April 2009, p. 79-91, 2014.

MEMARSADEGHI, N.. Citizen Science. Computing In Science \& Engineering, s.I., v. 17, n. 4, p.8-10, jul. 2012.

MIGOTTO, A. E.; TIAGO, C. G.; MAGALHÃES, A. E. M.. Malacofauna marinha da região costeira do Canal de São Sebastião, SP, Brasil: Gastropoda, Bivalvia, Polyplacophora e Scaphopoda. Bol. Inst. Oceanográfico. São Paulo, v. 41, n. 1/2, p. 13-27. [s. ed.], 1993.

MINISTÉRIO DO MEIO AMBIENTE. Instrução Normativa n 5, de 21 de maio de 2004. Diário da União. Brasília, DF.

MINISTÉRIO DO MEIO AMBIENTE. Instrução Normativa $n^{\circ} 9$, de 13 de junho de 2012. Diário Oficial da União. Brasília, DF.

MINISTÉRIO DO MEIO AMBIENTE. Portaria n 445, de 17 de dezembro de 2014. Diário da União. Brasília, DF.

MORINHA, F. et al. A spatially-explicit dynamic modelling framework to assess habitat suitability for endangered species: The case of Red-billed Chough under land use change scenarios in Portugal. Biological Conservation, [s.l.], v. 210, n. 1, p.96-106, jun. 2017. Elsevier BV. http://dx.doi.org/10.1016/j.biocon.2017.04.013.

NARCHI, W.; DARIO, F. di. The anatomy and functional morphology of Tivela ventricosa (Gray, 1838) (Bivalvia : Veneridae). The Nautilus, Melbourne, v. 116, n. 1, p.13-24, abr. 2002.

NARCHI, W.. Comparative Study of the Functional Morphology of Anomalocardia brasiliana (Gmelin, 1791) and Tivela mactroides (Born, 1778) (Bivalvia, Veneridae). Bul. Mar. Sci. [s.I.], v. 22, n. 3, p. 643-670. 1973.

NATURAM. Caraguatatuba. Disponível em: <https://naturam.com.br/caraguatatuba/>. Acesso em: 28 mar. 2019.

NORKKO, Alf et al. Size matters: implications of the loss of large individuals for ecosystem function. Scientific Reports, [s.I.], v. 3, n. 1, p.1-7, 12 set. 2013. Springer Nature. http://dx.doi.org/10.1038/srep02646.

NUCCI, P. R.; TURRA, A.; MORGADO, E. H.. Diversity and distribution of crustaceans from 13 sheltered sandy beaches along São Sebastião Channel, south-eastern Brazil. Journal Of The Marine Biological Association Of The Uk, [s.I.], v. 81, n. 03, p.475484, jun. 2001. Cambridge University Press (CUP). http://dx.doi.org/10.1017/s0025315401004118.

OBSERVATÓRIO LITORAL SUSTENTÁVEL (São Paulo). Instituto Pólis. Diagnóstico urbano socioambiental: Município de Ubatuba. Ubatuba: S. Ed., 2012. 547 p.

OCCDOWNLOAD GBIF.ORG. GBIF Occurrence DownloadThe Global Biodiversity Information Facility, , 2019. Disponível em: <https://www.gbif.org/occurrence/download/ 0008744-190320150433242>. Acesso em: 25 abr. 2019 
OLIVEIRA, N; R.; SANTOS, C. R. dos; TURRA, A.. Percepção ambiental como subsídio para gestão costeira da Baía do Araçá, Litoral Norte do Estado de São Paulo, Brasil. Desenvolvimento e Meio Ambiente, [s.I.], v. 44, p.140-163, 28 fev. 2018. Universidade Federal do Parana. http://dx.doi.org/10.5380/dma.v44i0.53825.

PETROBRÁS. Relatório de Finalização dos Projetos de Compensação da Atividade Pesqueira (PCAP) da Bacia de Santos. Rio de Janeiro: Sine Ed., 2007. $128 \mathrm{p}$.

PEZZUTO, P. R. et al. Environmental Impacts of the Nourishment of Balneário Camboriú Beach, SC, Brazil. Journal Of Coastal Research, S.I., v. 39, n. 1, p.863869, fev. 2006.

PIKITCH, E. K. et al. Ecosystem-Based Fishery Management. Science, [s.I.], v. 305, n. 5682, p.346-347, 16 jul. 2004. American Association for the Advancement of Science (AAAS). http://dx.doi.org/10.1126/science.1098222.

PINCINATO, F. L.. Mapeamento da sensibilidade ambiental a derramamentos de óleo para a região costeira de São Sebastião e Caraguatatuba, Litoral Norte de São Paulo (SP), com uso de modelagem em SIG de sistema especialista baseado em conhecimento e árvore de decisão. 2007. 72 f. Tese (Doutorado) - Curso de Geociências, Universidade Estadual Paulista, Rio Claro, 2007.

POFFO, I. R. F.; XAVIER, J. C. M.; SERPA, R. R.. A História dos 27 anos de Vazamento de Óleo no Litoral Norte do Estado de São Paulo (1974-2000). Revista Meio Ambiente Industrial, n. 30, p.98-104, 2001.

POSSINGHAM, H. P et al. Limits to the use of threatened species lists. Trends In Ecology \& Evolution, [s.I.], v. 17, n. 11, p.503-507, nov. 2002. Elsevier BV. http://dx.doi.org/10.1016/s0169-5347(02)02614-9.

POTASMAN, Israel; PAZ, Alona; ODEH, Majed. Infectious Outbreaks Associated with Bivalve Shellfish Consumption: A Worldwide Perspective. Clinical Infectious Diseases, [s.I.], v. 35, n. 8, p.921-928, 15 out. 2002. Oxford University Press (OUP). http://dx.doi.org/10.1086/342330.

PRAIAS-360. Praias-360. Disponível em: <http://www.praias-360.com.br/sao-paulo/>. Acesso em: 28 mar. 2019.

PREFEITURA MUNICIPAL DE CARAGUATATUBA. Alunos do CIEFI Massaguaçu fazem plantio de jundu na orla. Transparência. Caraguatatuba, p. 1-1. 06 jul. 2018

PREFEITURA MUNICIPAL DE CARAGUATATUBA. Atrativos. Disponível em: <http://www.turismocaragua.com.br/atrativos>. Acesso em: 28 mar. 2019.

PREFEITURA MUNICIPAL DE SÃO SEBASTIÃO. Busque a praia perfeita. Disponível em: <http://www.turismosaosebastiao.com.br/busque-a-praia-perfeita>. Acesso em: 28 mar. 2019.

PREFEITURA MUNICIPAL DE UBATUBA. Turismo Ubatuba. Disponível em: <https://turismo.ubatuba.sp.gov.br/praias/>. Acesso em: 10 ago. 2017.

PROJETO BERBIGÃO. Home. 2013. Disponível em: <http://projetoberbigao.org/>. Acesso em: 12 abr. 2019. 
REDPATH, S. M. et al. Understanding and managing conservation conflicts. Trends In Ecology \& Evolution, [s.I.], v. 28, n. 2, p.100-109, fev. 2013. Elsevier BV. http://dx.doi.org/10.1016/j.tree.2012.08.021.

RESSUREIÇÃO, R. D. São Sebastião. São Paulo: Humanitas, 2002. 256 p.

REYES-MARTÍNEZ, M. J. et al. Response of intertidal sandy-beach macrofauna to human trampling: An urban vs. natural beach system approach. Marine Environmental Research, [s.I.], v. 103, n. 1, p.36-45, fev. 2015. Elsevier BV. http://dx.doi.org/10.1016/j.marenvres.2014.11.005.

RIBEIRO, J. dos S. et al. Evolução da vulnerabilidade à erosão costeira na Praia de Massaguaçú (SP), Brasil. Revista de Gestão Costeira Integrada, [s.I.], p.253-265, 8 out. 2013. Associacao Portuguesa dos Recursos Hidricos (APRH). http://dx.doi.org/10.5894/rgci377.

RIOS, E. C.. Seashells of Brazil. Rio Grande, Brasil: Museu Oceanográfico da Fundação Universidade do Rio Grande; 1985.

ROCHA, A. A.; PEREIRA, N.; MALAGRINO, W. Efeitos de baixas concentrações de detergentes aniônicos sobre o hábito de escavação de Tivela mactróides (BORN, 1778), Bivalvia, Veneridae. Departamento de Saúde Ambiental, São Paulo, v. 45, n. 142, p.313-315, set. 1983.

ROCHA, T. C. F.. Mapeamento da sensibilidade ambiental do litoral de UbatubaSP a vazamentos de petróleo. 2008. 129 f. Dissertação (Mestrado) - Curso de Geociências e Meio Ambiente, Universidade Estadual Paulista, Instituto de Geociências e Ciências Exatas, Rio Claro, 2008.

RODRIGUES, A. et al. The value of the IUCN Red List for conservation. Trends in Ecology \& Evolution, [s.l.], v. 21, n. 2, p.71-76, fev. 2006. Elsevier BV. http://dx.doi.org/10.1016/j.tree.2005.10.010.

RODRÍGUEZ, J. P. et al. Establishing IUCN Red List Criteria for Threatened Ecosystems. Conservation Biology, [s.I.], v. 25, n. 1, p.21-29, 5 nov. 2010. Wiley. http://dx.doi.org/10.1111/j.1523-1739.2010.01598.x.

SANTOS, J. B.. Qualidade Ecotoxicológica do Sedimento de Caraguatatuba, SP. 2016. 104 f. Dissertação (Mestrado) - Curso de Oceanografia, Universidade de São Paulo, São Paulo, 2016.

SANTOS, M. F. L.; PIRES-VANIN, A. M. S.. Structure and dynamics of the macrobenthic communities of Ubatuba Bay, southeastern Brazilian Coast. Brazilian Journal Of Oceanography, São Paulo, v. 52, n. 1, p.59-73, mar. 2004. FapUNIFESP (SciELO). http://dx.doi.org/10.1590/s1679-87592004000100006.

SÃO PAULO (Estado). Resolução $n^{\circ}$ 002, de 16 de junho de 2015. Diário Oficial do Estado. São Paulo, SP, 17 jun. 2015.

SÃO PAULO. Bernadette Cunha Waldvogel. Fundação Sistema Estadual de Analise de Dados. A População Regional Paulista em Perspectiva Hitórica: Projeções Demográficas até 2050. São Paulo: S. Ed., 2017. 21 p.

SÃO PAULO. Celia Regina de Gouveia Souza. Instituto Geológico-SMA. Atualização 
do Mapa de Risco à Erosão Costeira para o Estado de São Paulo. São Paulo: Sine Ed., 2011. 3 p.

SÃO PAULO. Fundação Florestal. Governo do Estado de São Paulo. Sobre a APA. 2014b.

Disponível

em:

<http://fflorestal.sp.gov.br/unidades-de-conservacao/apas/areas-de-protecao-

ambiental-marinha-do-esta>. Acesso em: 12 maio 2017.

SÃO PAULO. Instituto de Pesca (IP). Secretaria de Agricultura e Abastecimento. Relatórios Públicos. Disponível em: <http://www.propesq.pesca.sp.gov.br/relatorio/30\#form-container>. Acesso em: 11 mar. 2019.

SÃO PAULO. Nádia Gilma Beserra de Lima. Secretaria do Meio Ambiente (Org.). Meio Ambiente Paulista: Relatório de Qualidade Ambiental 2018. São Paulo: Sine Ed., 2017b. 381 p.

SÃO PAULO. Resolução $n^{\circ}$ 02, de 02 de janeiro de 2015. Estabelece as condições para a utilização, em caráter excepcional, do caranguejo uçá (Ucides cordatus) como recurso pesqueiro faunístico.. Diário Oficial do Estado. São Paulo, SÃO PAULO, 22 jan. 2015b. p. 55-58.

SARDI, A. E. et al. Effects of an in situ diesel oil spill on oxidative stress in the clam Anomalocardia flexuosa. Environmental Pollution, [s.I.], v. 230, p.891-901, nov. 2017. Elsevier BV. http://dx.doi.org/10.1016/j.envpol.2017.07.040.

SARDI, A. E.; RAMOS, R.; GARCÍA, E. M.. Hydrocarbon Biomarkers Responses in the Bivalve, Tivela mactroides, Exposed to Polluted Sediments. Bulletin Of Environmental Contamination And Toxicology, [s.I.], v. 90, n. 1, p.1-8, 20 out. 2012. Springer Nature. http://dx.doi.org/10.1007/s00128-012-0862-x.

SCHÄFER, W.. Ecology and palaeoecology of marine environments. 9. ed. Edinburgh: Oliver \& Boyd, 1972. 568 p.

SCHLACHER, T. A.; THOMPSON, L,. Beach recreation impacts benthic invertebrates on ocean-exposed sandy shores. Biological Conservation, [s.I.], v. 147, n. 1, p.123132, mar. 2012. Elsevier BV. http://dx.doi.org/10.1016/j.biocon.2011.12.022.

SCHLACHER, Thomas A. et al. Sandy beaches at the brink. Diversity And Distributions, [s.I.], v. 13, n. 5, p.556-560, 14 maio 2007. Wiley. http://dx.doi.org/10.1111/j.1472-4642.2007.00363.x.

SERRÃO, P. F.. Dinâmica morfo-sedimentar da praia de Maresias, Litoral Norte do Estado de São Paulo. 2014. 50 f. TCC (Graduação) - Curso de Oceanografia, Universidade de São Paulo, São Paulo, 2014.

SHACKEROFF, J. M; CAMPBELL, L. M. Traditional ecological knowledge in conservation research: problems and prospects for their constructive engagement. Conservation \& Society, Beaufort, v. 5, n. 3, p.343-360, maio 2007.

SHEPPARD, N.; PITT, K. A.; SCHLACHER, T. A.. Sub-lethal effects of off-road vehicles (ORVs) on surf clams on sandy beaches. Journal Of Experimental Marine Biology And Ecology, [s.I.], v. 380, n. 1-2, p.113-118, nov. 2009. Elsevier BV. http://dx.doi.org/10.1016/j.jembe.2009.09.009. 
SHUKLA, J. B. et al. Degradation and subsequent regeneration of a forestry resource: A mathematical model. Ecological Modelling, [s.l.], v. 44, n. 3-4, p.219-229, jan. 1989. Elsevier BV. http://dx.doi.org/10.1016/0304-3800(89)90031-8.

SINBIOTA. Sobre o SinBiota. 2017. Disponível em: <http://sinbiota.biota.org.br/occurrence/>. Acesso em: 24 mar. 2017.

SOUSA-BAENA, M. S.; GARCIA, L. C.; PETERSON, A. Townsend. Knowledge behind conservation status decisions: Data basis for "Data Deficient" Brazilian plant species. Biological Conservation, [s.I.], v. 173, p.80-89, maio 2014. Elsevier BV. http://dx.doi.org/10.1016/j.biocon.2013.06.034.

SOUSA, P. H..; SIEGLE, E.; TESSLER, M. G.. Vulnerability assessment of Massaguaçú Beach (SE Brazil). Ocean \& Coastal Management, [s.I.], v. 77, n. 1, p.24-30, jun. 2013. Elsevier BV. http://dx.doi.org/10.1016/j.ocecoaman.2012.03.003.

SOUZA, C. R. G. Praias arenosas oceânicas o estado de São Paulo (Brasil): síntese dos conhecimentos sobre morfodinâmica, sedimentologia, transporte costeiro e erosão costeira. Geography Department, University of Sao Paulo, [s.I.], p.307-371, 2012. Geography Department, University of Sao Paulo. http://dx.doi.org/10.7154/rdg.2012.0112.0015.

SOUZA, C. R. G.; LUNA, G. da C.. Taxas de retrogradação e balanço sedimentar em praias sob risco muito alto de erosão no município de Ubatuba (Litoral Norte de São Paulo). Quaternary And Environmental Geosciences, [s.I.], v. 1, n. 1, p.25-41, 30 jun. 2009. Universidade Federal do Parana. http://dx.doi.org/10.5380/abequa.v1i1.14489.

SOUZA, C. R. G.. As células de deriva litorânea nas praias do estado de São Paulo. 1997. 204 f. Tese (Doutorado) - Curso de Geologia Sedimentar, Universidade Federal de São Paulo, São Paulo, 1997.

SOUZA, C. R. G.. Impactos das mudanças climáticas no Litoral do Estado de São Paulo (sudeste do Brasil) In: Seminário Ibero Americano de Geografia Física, 2., 2010, Coimbra. Resumos. Coimbra: Universidade de Coimbra, 2010. p. 1 - 17.

SPECIESLINK, Coleção de Moluscos (MCP-Moluscos), OBIS Brasil (OBIS_BR), Sistema de Informação do Programa Biota/Fapesp (SinBiota), Coleção de Bivalvia do Museu de Zoologia da UNICAMP (ZUEC-BIV). Disponível em <http://www.splink.org.br>. Acesso em: 14 jun. 2017.

SULLIVAN, B. L. et al. Using open access observational data for conservation action: A case study for birds. Biological Conservation, [s.I.], v. 208, p.5-14, abr. 2017. Elsevier BV. http://dx.doi.org/10.1016/j.biocon.2016.04.031.

TEIXEIRA, L. R.; IWAMA, A. Y.. Caracterização dos grandes projetos de infraestrutura do Litoral Norte paulista. In: SANTOS, Claudia Regina dos; TURRA, Alexander (Org.). RUMOS DA SUSTENTABILIDADE COSTEIRA: UMA VISÃO DO LITORAL NORTE PAULISTA. São Paulo: Sine Ed., 2017. p. 98-153.

TESSLER, M, G et al. São Paulo. In: MUEHE, D. (Org.). Erosão e Progradação do Litoral Brasileiro. São Paulo: MMA, 2006. Cap. 13. p. 297-346. 
TESSLER, M. G.; GOYA, S. C. y. Processos Costeiros Condicionantes do Litoral Brasileiro. Revista do Departamento de Geografia, São Paulo, v. 17, n. 1, p.11-23, jan. 2005.

TOLEDO, V. M. M.; BARRERA-BASSOLS, N.. A etnoecologia: uma ciência pós-normal que estuda as sabedorias tradicionais. Desenvolvimento e Meio Ambiente, [s.l.], v. 20, p.31-46, 21 dez. 2009. Universidade Federal do Parana. http://dx.doi.org/10.5380/dma.v20i0.14519.

TOMASINI, S.. Unpacking the Red List: Use (and Misuse?) of Expertise, Knowledge, and Power. Conservation And Society, [s.I.], v. 16, n. 4, p.505-518, 2018. Medknow. http://dx.doi.org/10.4103/cs.cs_16_52.

TOMMASI, L. R. Diagnóstico ambiental oceânico e costeiro das regiões sul e sudeste do Brasil. FUNDESPA/PETROBRÁS. Rio de Janeiro, 1994;. v 9/10v.

TURRA, A. et al. Assessment of recreational harvesting of the trigonal clam Tivela mactroides: Socioeconomic aspects and environmental perception. Fisheries Research, [s.I.], v. 174, p.58-67, fev. 2016. Elsevier BV. http://dx.doi.org/10.1016/j.fishres.2015.08.026.

TURRA, A. et al. Environmental Impact Assessment Under an Ecosystem Approach: the São Sebastião Harbor Expansion Project. Ambiente \& Sociedade, [s.I.], v. 20, n. 3, p.155-176, set. 2017. FapUNIFESP (SciELO). http://dx.doi.org/10.1590/18094422asoc166v2022017.

TURRA, A. et al. Frequency, magnitude, and possible causes of stranding and massmortality events of the beach clam Tivela mactroides (Bivalvia: Veneridae). Plos One, [s.I.], v. 11, n. 1, p.1-11, 8 jan. 2016. Public Library of Science (PLoS). http://dx.doi.org/ 10.1371/journal.pone.0146323.

TURRA, A. et al. Population biology and secondary production of the harvested clam Tivela mactroides (Born, 1778) (Bivalvia, Veneridae) in Southeastern Brazil. Marine Ecology, [s.I.], v. 36, n. 2, p.221-234, 6 maio 2014. Wiley-Blackwell. http://dx.doi.org/10.1111/maec.12137.

TURRA, A. et al. Temporal variation in life-history traits of the clam Tivela mactroides (Bivalvia: Veneridae). Estuarine, Coastal and Shelf Science, [s.I.], v. 150, p.157-164, out. 2015. Elsevier BV. http://dx.doi.org/10.1016/j.ecss.2013.06.004.

TURRA, A.; DENADAI, M. R.. O marisco-da-areia (berbigão) na Enseada de Caraguatatuba. Ubatuba: Instituto Costa Brasilis, 2005. 11 p.

TURRA, A.. Conservação marinha - histórico, bases conceituais e estratégias. In: Biologia Marinha. [s.I.]: [s.p.], 2017, in press.

U. S. FISH AND WILDLIFE SERVICE. Habitat Evaluation Procedures. Washington: S. Ed., 1980. 29 p.

UNELL, J. CASTLE, R. 2012. Developing sustainable volunteering within the Natural Connections Demonstration Project: A review of evidence. Natural England Commissioned Reports, London, 2012. 
UNITED NATIONS CONFERENCE ON ENVIRONMENT AND DEVELOPMENT, Declaração do Rio de Janeiro. Estud. av., São Paulo , v. 6, n. 15, p. 153-159, Aug. 1992. http://dx.doi.org/10.1590/S0103-40141992000200013

WEBB, T. J.; MINDEL, B. I.. Global Patterns of Extinction Risk in Marine and Nonmarine Systems. Current Biology, [s.I.], v. 25, n. 4, p.506-511, fev. 2015. Elsevier BV. http://dx.doi.org/10.1016/j.cub.2014.12.023.

WEST, S.; PATEMAN, R. Recruiting and Retaining Participants in Citizen Science: What Can Be Learned from the Volunteering Literature?. Citizen Science: Theory and Practice, [s.I.], v. 1, n. 2, p.1-10, 31 dez. 2016. Ubiquity Press, Ltd.. http://dx.doi.org/10.5334/cstp.8.

WNUK, K.; GARREPALLI, T.. Knowledge Management in Software Testing:A Systematic Snowball Literature Review. E-informatica Software Engineering Journal, [s.I.], v. 12, n. 1, p.51-78, jan. 2018.

WYN-JONES, A. Peter et al. Surveillance of adenoviruses and noroviruses in European recreational waters. Water Research, [s.I.], v. 45, n. 3, p.1025-1038, jan. 2011. Elsevier BV. http://dx.doi.org/10.1016/j.watres.2010.10.015.

YANG, Y. Adjusting for Perception Bias in Citizens' Subjective Evaluations. Public Performance \& Management Review, [s.I.], v. 34, n. 1, p.38-55, 1 set. 2010. Informa UK Limited. http://dx.doi.org/10.2753/pmr1530-9576340103.

YOKOYAMA, C. K.; SIEGLE, E.. Mobilidade sedimentar da plataforma continental do Estado de São Paulo em função da propagação de ondas. 2013. $68 \mathrm{f}$. Dissertação (Mestrado) - Curso de Oceanografia, Universidade Federal de São Paulo, São Paulo, 2013.

YOUNG, J. C. et al. A methodological guide to using and reporting on interviews in conservation science research. Methods In Ecology And Evolution, [s.I.], v. 9, n. 1, p.10-19, jan. 2018. Wiley. http://dx.doi.org/10.1111/2041-210x.12828.

ZAPPONI, L. et al. Citizen science data as an efficient tool for mapping protected saproxylic beetles. Biological Conservation, [s.l.], v. 208, p.139-145, abr. 2017. Elsevier BV. http://dx.doi.org/10.1016/j.biocon.2016.04.035. 
ICON CREDITS

All icons used in the maps were sourced from OpenMoji (http://openmoji.org/) and the following creators from Flaticon (www.flaticon.com):

- Smashicons

- $\quad$ Freepik

- $\quad$ srip

- Good Ware

- $\quad$ mavadee

- $\quad$ Creaticca Creative Agency

- $\quad$ Swifticons 


\section{ANNEX 1}

Sources of the data used to improve the Simplified Habitat Suitability (SHS).

\begin{tabular}{|c|c|c|}
\hline Source & Characteristic & Beaches \\
\hline Coelho (2016) & Grain Size & Paúba \\
\hline Serrão (2014) & Grain Size, Slope & Maresias \\
\hline Antoneli (2004) & Grain Size & $\begin{array}{l}\text { Juquehy; Havaizinho; Conchas; Preta (São Sebastião); } \\
\text { Barra do Sahy }\end{array}$ \\
\hline Andrade (2002) & Grain Size & Fortaleza \\
\hline Cardoso (2013) & Grain Size & Lázaro; Domingas Dias; Sununga \\
\hline $\begin{array}{l}\text { Hurtado, Goya e } \\
\text { Tessler (2016) }\end{array}$ & Grain Size, Slope & Itamambuca \\
\hline Narchi (1973) & Grain Size & Itaguá \\
\hline Barros (1997) & Grain Size & Fazenda; Puruba; Itaguá \\
\hline Martins (2006) & Grain Size & Sununga \\
\hline $\begin{array}{l}\text { Gubitoso et al. } \\
(2008)\end{array}$ & Grain Size & Araçá \\
\hline Bers et al. (2013) & Grain Size & Caraguatatuba Bay \\
\hline $\begin{array}{l}\text { Santos e Pires- } \\
\text { Vanin }(2004)\end{array}$ & Grain Size & Perequê-açu; Iperoig; Itaguá; Vermelha \\
\hline Santos (2016) & Grain Size & $\begin{array}{l}\text { Enseada (São Sebastião); Caraguatatuba Beach; } \\
\text { Martim Sá; Mococa; Tabatinga }\end{array}$ \\
\hline Souza (1997) & $\begin{array}{l}\text { Grain Size, Slope, } \\
\text { Exposure }\end{array}$ & $\begin{array}{l}\text { Juquehy; Baleia; Boiçucanga; Maresias; Toque-Toque } \\
\text { Pequeno; Guaecá; Barequeçaba; Caragutatuba; } \\
\text { Massaguaçú; Mococa; Martim de Sá; Tabatinga; } \\
\text { Maranduba; Sapé; Lagoinha; Fortaleza; Vermelha da } \\
\text { Fortaleza; Lázaro; Dura; Itaguá }\end{array}$ \\
\hline $\begin{array}{l}\text { Amaral et al. } \\
(2003)\end{array}$ & Grain Size, Slope & Caraguatatuba Bay \\
\hline $\begin{array}{l}\text { Nucci, Turra e } \\
\text { Morgado (2001) }\end{array}$ & $\begin{array}{l}\text { Grain Size, Slope, } \\
\text { Exposure }\end{array}$ & $\begin{array}{l}\text { Araçá, Barequeçaba; Pontal da Cruz; Siriúba; } \\
\text { Garapocaia; Cigarras; Praia Grande (São Sebastião); } \\
\text { Enseada (São Sebastião); Segredo; Barra Velha; } \\
\text { Engenho d'Água; São Francisco }\end{array}$ \\
\hline
\end{tabular}




\section{ANNEX 2}

\section{Strategies for evaluating the cockle Tivela mactroides (Born, 1778) (Bivalvia) for classification in the List of Threatened Species of the State of São Paulo}

Researcher:

Date:

1. On which beaches of the North Coast have you observed Tivela mactroides?

2. In what year was the first time you observed T. mactroides on this beach?

3. Does T. mactroides still exist on this beach? a. Yes; b. No; c. I don't know.

4. If not or do not know, when was the last year you saw it?

5. If so, do you think the number of organisms has changed since the first time you observed T. mactroides? a. Yes; b. No; c. I don't know.

6. If so, how did it change?

7. Do you think there is any threat to populations of T. mactroides?

8. If so, is it possible to point out specific threats to each beach?

9. If so, what are these specific threats to each beach?

10. Do you think the intensity of any of the threats on the beach will change in the future? a. Yes; b. No; c. I don't know.

11. If yes, how (for more, for less) and why?

12. Given the intensity of the threats, is it possible for T. mactroides to disappear on this beach? a. No; b. Yes, within 20 years; c. Yes, within 100 years; d. I don't know.

13. If not, what would these threats be?

14. Do you think that the intensity of threats will change in the future? a. Yes; b. No; c. I don't know.

15. If intensity will change, how (for more, for less) and why?

16. Considering the intensity of the threats, is it possible that T. mactroides will disappear on the North Coast of São Paulo?

a. No; b. Yes, within 20 years; c. Yes, within 100 years; d. I don't know.

17. Any further comments?

18. Do you know anyone else with experience and knowledge about $T$. mactroides or the North Coast who can help with this research? 
ANNEX 3

\section{TERM OF FREE AND ENLIGHTENED CONSENT \\ (Maiores de 18 anos)}

You are being invited to participate in the research project mentioned above. This document contains the necessary information about the research we are doing. Your collaboration in this study will be of great importance to us.

I,....... resident and domiciled in bearer of the Identity Card, RG enrolled in the CPF. born in I _ undersigned, freely agree to participate in the study Strategies for evaluating the cockle Tivela mactroides (Born, 1778) (Bivalvia) for classification in the List of Endangered Species of the State of São Paulo, and I clarify that I have obtained all the necessary information. I am aware that:

I) The study is necessary to increase the knowledge about Tivela mactroides cockle, including the places in which it lives and the size of the population, and to provide information for its use and conservation;

II) As a methodology of the study, interviews will be conducted through a questionnaire and audio recording.

III) Participation in this research does not involve physical risks. However, there may be discomfort due to the presence of the recorder;

IV) I have the freedom to give up or interrupt the collaboration in this study at the moment you wish, without the need for any explanation;

V) The results obtained during this research will be kept confidential, but I agree to be published in scientific publications, provided that the personal data that allow my identification are not mentioned;

$\mathrm{VI}$ ) If I wish, I will be able to know the results at the end of this research.

- I want to know the results of this research. Email:

- I do not want to know the results of this research.

VII) If photographs have been taken:

- I agree to include them in scientific publications or presentations;

- I agree to include them in scientific publications or presentations if my face does not appear or is out of focus;

- I do not agree that they are included in any type of publication or presentation.

VIII) The collected material will be stored under the responsibility of the Institute of Biosciences - USP and under the custody of Thaís Fonseca Rech, for the time necessary for the data analysis and adequate mapping and characterization of the 
results and their influence for the research area.

São Paulo, de de $20 \ldots \ldots$

Signature of Participant

Signature of the Researcher Responsible for the Project

Thaís Fonseca Rech

Graduate Student of Biological Oceanography Course at IOUSP

(11) 958379506

thais.rech@usp.br

If there are doubts about the ethical aspects of this study, you can consult:

Researcher Responsible: Thaís Fonseca Rech

Address: Oceanographic Institute of the University of São Paulo

Plaza do Oceanográfico, 191, Room 112 - CEP: 05508-120

University City, São Paulo (SP) - Brazil

e-mail: thais.rech@usp.br

Phone for contact: (11) 958379506

Advisor: Alexander Turra

Address: Oceanographic Institute of the University of São Paulo

Plaza do Oceanográfico, 191, Room 112 - CEP: 05508-120

University City, São Paulo (SP) - Brazil

e-mail: turra@usp.br

Phone for contact: (11) 30916594

To contact CEP-IB:

Research Ethics Committee - Human Beings (CEP) of the Institute of Biosciences of the University of São Paulo

Rua do Matão - travessa 14, 321 - Cidade Universitária, CEP: 05508-090 - São Paulo SP

Telephone (11) 3091-8761 - e-mail: cepibusp@ib.usp.br. 


\section{ANNEX 4}

Strategies for evaluating the cockle Tivela mactroides (Born, 1778) (Bivalvia) for classification in the List of Threatened Species of the State of São Paulo Local:

Date:

Interviewee:

1. Do you know this animal? a. Yes; b. No.

2. How do you name this animal?

3. Is it the same as this one? (interviewer shows shells of Anomalocardia brasiliana) a. Yes; b. No; c. I don't know.

4. On which beaches on the north coast have you ever seen this animal?

5. In what year was the first time you saw this animal on this beach?

6. Is there still this animal on this beach? a. Yes; b. No; c. I don't know

7. If not, when was the last year you saw it?

8. Do you think the number of organisms has changed since the first time you saw this animal? a. Yes; b. No; c. I don't know.

9. If so, how did it change?

10. Do you think that there is a threat to this animal (something that can make the amount of this animal decrease / disappear)? a. Yes; b. No; c. I don't know.

11. If so, is it possible to point out specific threats to each beach? a. Yes; b. No; c. I don't know

12. If so, what are these specific threats to each beach?

13. Do you think the intensity of these threats on each beach will change in the future?

a. Yes; b. No; c. I don't know.

14. If so, what threats, how and why?

15. If the threats are the same for each beach, what are these threats?

16. Do you think the intensity of these threats will change in the future? a. Yes;

b. No; c. I don't know.

17. If so, what threats, how and why?

18. Do you know anyone else with experience and knowledge about this animal that can help with this research?

19. Any further comments? 


\section{ANNEX 5}

Below is the text of the online questionnaire, sent to followers of the social media pages, in order to find possible interviewees. The questions were illustrated with photos of T. mactroides and Anomalocardia brasiliana, and of the types of beaches, to aid the understanding of the questions.

\section{DO YOU KNOW THIS ANIMAL?}

My name is Thaís Fonseca Rech, I am a graduate student of Biological Oceanography at the Oceanographic Institute of the University of São Paulo, directed by Prof. Alexander Turra. In my master's work, I am trying to estimate on which beaches a bivalve mollusk called Tivela mactroides appears in the municipalities of the Northern Coast of São Paulo. This organism has many names, among them mussels, clam or shellfish. I'll call it a clam, because that's the name I'm used to.

To find where this animal is, in addition to searching the scientific literature, I am looking for people who know this clam. This species is on the List of Threatened Species of Extinction of the State of São Paulo and is also an important food resource, which makes its conservation a delicate subject that must take into account these two factors. Your knowledge about mussels can help with this process! To help me, just answer the questionnaire.

From this questionnaire, I will select some people for a more in-depth interview, with more details of where and when you saw this mussel. If you want to participate in the next phases of the study, you will have the opportunity to post your email later. When filling in your email, you agree to participate in this questionnaire. By participating in this questionnaire, you state: - That you are over 18 years old; - That their consent to participate in this research refers only to the electronic questionnaire present; - That you were informed about the objectives of the study; - That is aware that the methodology of this study includes interviews via electronic questionnaire; That is aware that this research does not include physical risks, but that there may be some drawbacks caused by the electronic form; - That you can quit at any time, just leave the questionnaire, without any embarrassment; - That the results obtained during this research will be kept confidential, but agrees that they be published in scientific publications, provided that the personal data that allow their identification are not mentioned; - That material collected will be stored under the responsibility of the Institute of Biosciences - USP and under the custody of Thaís Fonseca Rech, for the 
time necessary to analyze the data; - That you accept that I contact for participation in the next phase of my research.

Do not worry, if you are chosen to participate in the interviews, I will ask again if there is interest in continuing to participate.

Email address:

1. Do you know this clam?

a. Yes; b. No; c. I don't know

2. On what types of coast does this clam live?

a. Beaches with coarse sand, "de tombo" (Ex.: Pauba Beach); b. Beaches with fine sand (Ex.: Indaia); d. Muddy beaches or mudflats (Ex.: Araça Bay Beach); e. Mangrove (Ex.: Araça Mangrove); f. Other.

3. Have you seen this clam on the beaches of the municipalities below? a. São Sebastião; b. Ilhabela; c. Caraguatatuba; d. Ubatuba; e. None.

4. Is the animal in the photo below the same species as the first photo? a. Yes; b. No; c. I don't know. 


\section{ANNEX 6}

List of the beaches, with the papers which recorded Tivela mactroides (1), the names of the collections (2), the Simplified Habitat Suitability value (3), the number of evidences of the presence of Tivela mactroides from interviews with experts (4), from citizen science (5), interviews with communities (6) and shell observation (7).

\begin{tabular}{|c|c|c|c|c|c|c|c|c|}
\hline \multirow[b]{2}{*}{ Beach } & \multirow[b]{2}{*}{ Municipality } & \multicolumn{7}{|c|}{ Sources of information } \\
\hline & & 1. Literature & 2. Collections & 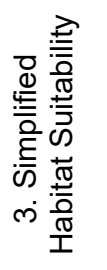 & 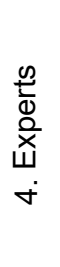 & 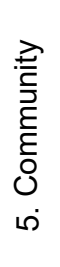 & 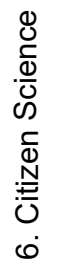 & 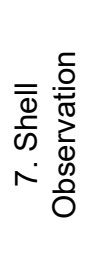 \\
\hline $\begin{array}{l}\text { Enseada de } \\
\text { Caraguatatuba (Enseada, } \\
\text { Porto Novo/Palmeiras, } \\
\text { Flecheiras, Centro, Pan- } \\
\text { Brasil, Indaiá, Romance, } \\
\text { Camaroeiros) }\end{array}$ & $\begin{array}{l}\text { São Sebastião } \\
\text { Caraguatatuba }\end{array}$ & $\begin{array}{l}\text { Arruda, Domaneschi e } \\
\text { Amaral (2003); Amaral, et } \\
\text { al. (2003); Denadai, } \\
\text { Amaral e Turra (2005b); } \\
\text { Denadai, et al. (2006); } \\
\text { Leal (2008); Introini et al. } \\
\text { (2009); Bers et al. (2013); } \\
\text { Caobelli (2016). }\end{array}$ & $\begin{array}{l}\text { SINBIOTA; } \\
\text { ZUEC-BIV; } \\
\text { OBIS_BR; }\end{array}$ & 7 & 8 & 7 & 15 & \\
\hline Fazenda & Ubatuba & $\begin{array}{l}\text { Denadai, E.P.; } \\
\text { Domaneschi, O. and } \\
\text { Amaral, A.C.Z. (2003) }\end{array}$ & $\begin{array}{l}\text { OBIS_BR; } \\
\text { SINBIOTA; } \\
\text { MZUSP; } \\
\text { ZUEC-BIV². }\end{array}$ & 7 & 1 & 3 & 2 & \\
\hline Preta (Costa Sul) & São Sebastião & & & 7 & & & & Yes \\
\hline Almada & Ubatuba & & & 6 & & & & No \\
\hline Baleia & São Sebastião & & $\begin{array}{l}\text { ZUEC-BIV; } \\
\text { MZUSP. }\end{array}$ & 6 & & & & Yes \\
\hline $\begin{array}{l}\text { Barequeçaba } \\
\text { (Baraqueçaba) }\end{array}$ & São Sebastião & $\begin{array}{l}\text { Migotto, Tiago e } \\
\text { Magalhães, (1993);Corte } \\
\text { (2016). }\end{array}$ & $\begin{array}{l}\text { MZUSP; NHM/ } \\
\text { Rotterdam. }\end{array}$ & 6 & 3 & & 7 & \\
\hline Boracéia & São Sebastião & & & 6 & & & 1 & \\
\hline Engenho & São Sebastião & & & 6 & & & & Yes \\
\hline Enseada & Ubatuba & & $\begin{array}{l}\text { MZUSP; } \\
\text { SINBIOTA. }\end{array}$ & 6 & & 3 & & \\
\hline Estaleiro do Padre & Ubatuba & & & 6 & & & & Yes \\
\hline Itaguá & Ubatuba & Narchi (1973). & MZUSP; & 6 & 3 & 8 & 1 & \\
\hline Lagoinha & Ubatuba & & MZUSP. & 6 & & 4 & & \\
\hline Tenório & Ubatuba & & & 6 & & & & No \\
\hline Toninhas & Ubatuba & & MZUSP. & 6 & & 2 & 2 & \\
\hline Ubatumirim & Ubatuba & & MZUSP. & 6 & 1 & 3 & 5 & \\
\hline Alto & Ubatuba & & & 5 & & & 1 & \\
\hline Barra do Sahy & São Sebastião & & & 5 & & & 4 & \\
\hline Bonete & Ilhabela & & MZUSP. & 5 & & 1 & & \\
\hline
\end{tabular}

2 The specimens in these collections have very similar field information, so they may be from the same survey 


\begin{tabular}{|c|c|c|c|c|c|c|c|}
\hline Brava da Almada & Ubatuba & & 5 & & 1 & & \\
\hline Brava de Boiçucanga & São Sebastião & & 5 & & & & \\
\hline Brava de Guaecá & São Sebastião & & 5 & & & & \\
\hline Brava do Camburi & Ubatuba & & 5 & & & & \\
\hline Calhetas & São Sebastião & & 5 & & & & \\
\hline Cambury & São Sebastião & & 5 & & & & Yes \\
\hline Castelhanos & Ilhabela & & 5 & & & & \\
\hline Cedro (Cedrinho) & Ubatuba & & 5 & & & & \\
\hline Centro & São Sebastião & & 5 & & & & No \\
\hline Conchas & São Sebastião & & 5 & & & & \\
\hline Dura & Ubatuba & MZUSP. & 5 & & 3 & & \\
\hline Engenho & Ubatuba & & 5 & & & & \\
\hline Eustáquio & Ilhabela & & 5 & & & & \\
\hline Félix & Ubatuba & & 5 & & 1 & & \\
\hline Fortaleza & Ubatuba & & 5 & 2 & 1 & & \\
\hline Freira (Garcez) & Caraguatatuba & & 5 & & & & \\
\hline Grande & Ubatuba & MZUSP. & 5 & 1 & 1 & & \\
\hline Itamambuca & Ubatuba & & 5 & & 1 & & \\
\hline Juquehy & São Sebastião & & 5 & & & 2 & \\
\hline Maranduba & Ubatuba & & 5 & 1 & 4 & & \\
\hline Perequê-Açú & Ubatuba & $\begin{array}{l}\text { MZUSP; } \\
\text { SINBIOTA; } \\
\text { NHM/ } \\
\text { Rotterdam; } \\
\text { BMSM/Florida; } \\
\text { MCP-MOL; } \\
\text { Tarasconi; }\end{array}$ & 5 & & 1 & 1 & \\
\hline Porto Grande & São Sebastião & & 5 & & & & No \\
\hline Armação & Ilhabela & & 4 & & & & \\
\hline Arrastão & São Sebastião & & 4 & & & & \\
\hline Barra do Una & São Sebastião & FZB/RS. & 4 & & & & \\
\hline Barra Seca & Ubatuba & $\begin{array}{l}\text { MZUSP; } \\
\text { Museu } \\
\text { Nacional/RIO. }\end{array}$ & 4 & & 2 & & \\
\hline Barra Velha & Ilhabela & & 4 & & 1 & & \\
\hline Barreiros & Ilhabela & MZUSP. & 4 & & & & \\
\hline Brava da Boracéia & São Sebastião & & 4 & & & & \\
\hline Brava da Fortaleza & Ubatuba & & 4 & & & & \\
\hline Caçandoquinha & Ubatuba & & 4 & & & & \\
\hline Camburi & Ubatuba & & 4 & & 1 & & \\
\hline Camburizinho & São Sebastião & & 4 & & & & \\
\hline Caveira & Ilhabela & & 4 & & & & \\
\hline Cedro do Sul & Ubatuba & & 4 & & & & \\
\hline Cigarras & São Sebastião & & 4 & & & & \\
\hline Costa & Ubatuba & & 4 & & & 1 & \\
\hline
\end{tabular}




\begin{tabular}{|c|c|c|c|c|c|c|c|c|}
\hline Deserta & São Sebastião & & & 4 & & & & \\
\hline Dionísia & Ubatuba & & & 4 & & & & \\
\hline $\begin{array}{l}\text { Engenho d'Água } \\
\text { (Pequeá) }\end{array}$ & Ilhabela & & MZUSP. & 4 & & & & \\
\hline Enseada do Araçá & São Sebastião & $\begin{array}{l}\text { Migotto, Tiago e } \\
\text { Magalhães, (1993); } \\
\text { Belucio (1995); Corte } \\
(2016) .\end{array}$ & MZUSP. & 4 & & 1 & & \\
\hline Figueira & Ubatuba & & & 4 & & & & \\
\hline Figueira & São Sebastião & & & 4 & & & & \\
\hline Flamengo & Ubatuba & & & 4 & & & & \\
\hline Flamenguinho & Ubatuba & & & 4 & & & & \\
\hline Fome & Ilhabela & & & 4 & & & & \\
\hline $\begin{array}{l}\text { Garapucaia (Pedra do } \\
\text { Sino) }\end{array}$ & Ilhabela & & $\begin{array}{l}\text { Tarasconi; } \\
\text { MZUSP. }\end{array}$ & 4 & & & & \\
\hline $\begin{array}{l}\text { Grande (Balneário dos } \\
\text { Trabalhadores) }\end{array}$ & São Sebastião & & MZUSP. & 4 & & & 1 & \\
\hline Grande do Bonete & Ubatuba & & & 4 & & & & \\
\hline Guaecá & São Sebastião & & & 4 & 3 & & 2 & \\
\hline Havaizinho & São Sebastião & & & 4 & & & & \\
\hline Indaiaúba & Ilhabela & & & 4 & & & & \\
\hline Itaguaçu & Ilhabela & & Tarasconi. & 4 & & & & \\
\hline Itaquanduba & Ilhabela & & & 4 & & & & \\
\hline Jabaquara & Ilhabela & & & 4 & & & & \\
\hline Julião & Ilhabela & & & 4 & & & & \\
\hline Juréia & São Sebastião & & & 4 & & & & \\
\hline Lagoa & Ubatuba & & & 4 & & 1 & & \\
\hline Mansa & Ubatuba & & & 4 & & & & \\
\hline Mansa & Ilhabela & & & 4 & & & & \\
\hline Maresias & São Sebastião & & & 4 & 1 & & & \\
\hline Martim de Sá & Caraguatatuba & & MZUSP. & 4 & & & & \\
\hline Pacuiba & Ilhabela & & & 4 & & & & \\
\hline Paúba & São Sebastião & & Femorale. & 4 & & & & \\
\hline Pedras Miúdas & Ilhabela & & Tarasconi & 4 & 1 & & & \\
\hline Perequê & Ilhabela & & & 4 & 1 & & & \\
\hline Pinto & Ilhabela & & & 4 & & & & \\
\hline Ponta Aguda & Ubatuba & & & 4 & & 1 & & \\
\hline Ponta Azeda & Ilhabela & & & 4 & & & & \\
\hline Pontal da Cruz & São Sebastião & & & 4 & & & & \\
\hline Portal da Olaria & São Sebastião & & & 4 & & & & \\
\hline Prainha & Caraguatatuba & & & 4 & & & & \\
\hline Puruba & Ubatuba & & & 4 & & & & \\
\hline Saco da Capela & Ilhabela & & & 4 & & & & \\
\hline Saco da Ribeira & Ubatuba & & MZUSP; & 4 & & 2 & & \\
\hline
\end{tabular}




\begin{tabular}{|c|c|c|c|c|c|c|c|c|}
\hline & & & $\begin{array}{l}\text { Museu } \\
\text { Nacional/RIO }\end{array}$ & & & & & \\
\hline Santa Teresa & Ilhabela & & & 4 & & & & \\
\hline Santiago & São Sebastião & & & 4 & & & & \\
\hline São Francisco & São Sebastião & & & 4 & & & & \\
\hline Sapê & Ubatuba & & & 4 & & & & \\
\hline Segredo & São Sebastião & & & 4 & & & & \\
\hline Serraria & Ilhabela & & & 4 & & & & \\
\hline Sete Fontes & Ubatuba & & & 4 & & & & \\
\hline Simão (Brava do Frade) & Ubatuba & & & 4 & & & & \\
\hline Siriúba & Ilhabela & & & 4 & & & & \\
\hline Tabatinga & Caraguatatuba & & MZUSP. & 4 & & 1 & & \\
\hline Timbó (Zimbro) & São Sebastião & $\begin{array}{l}\text { Migotto, Tiago e } \\
\text { Magalhães (1993). }\end{array}$ & & 4 & & & & \\
\hline Vermelha & Ilhabela & & & 4 & & & & \\
\hline Vermelha do Norte & Ubatuba & & & 4 & & & & \\
\hline Viana & Ilhabela & & & 4 & & & & \\
\hline Vila & Ilhabela & & MZUSP. & 4 & & & & \\
\hline Boiçucanga & São Sebastião & & & 3 & & & & \\
\hline Bonete (Bonetinho) & Ubatuba & & & 3 & & & & \\
\hline Brava & Caraguatatuba & & & 3 & & & & \\
\hline Cabelo Gordo & São Sebastião & & & 3 & & & & \\
\hline Caçandoca & Ubatuba & & & 3 & & & & \\
\hline Cocanha & Caraguatatuba & & & 3 & & 1 & & \\
\hline Codó & Ubatuba & & & 3 & & & & \\
\hline Curral & Ilhabela & & & 3 & & & & \\
\hline Domingas Dias & Ubatuba & & MZUSP. & 3 & & & & \\
\hline Enchovas (Anchovas) & Ilhabela & & & 3 & & & & \\
\hline Grande & Ilhabela & & Tarasconi. & 3 & & & & \\
\hline $\begin{array}{l}\text { Iperoig (Cruzeiro) } \\
\text { (Centro) }\end{array}$ & Ubatuba & & MZUSP. & 3 & & & & \\
\hline Justa & Ubatuba & & & 3 & & & & \\
\hline Lázaro & Ubatuba & & MZUSP. & 3 & 2 & 1 & & \\
\hline Massaguaçu & Caraguatatuba & & $\begin{array}{l}\text { Tarasconi; } \\
\text { MZUSP. }\end{array}$ & 3 & & & & \\
\hline Matarazzo & Ubatuba & & & 3 & & & & \\
\hline Mococa & Caraguatatuba & & MZUSP. & 3 & 1 & & & \\
\hline Oscar & Ilhabela & & & 3 & & & & \\
\hline Perequê-Mirim & Ubatuba & & & 3 & & 1 & & \\
\hline Peres & Ubatuba & & & 3 & & & & \\
\hline Preta (Centro) & São Sebastião & & & 3 & & & & \\
\hline Prumirim & Ubatuba & & & 3 & & & & \\
\hline Pulso & Ubatuba & & & 3 & & & & \\
\hline
\end{tabular}




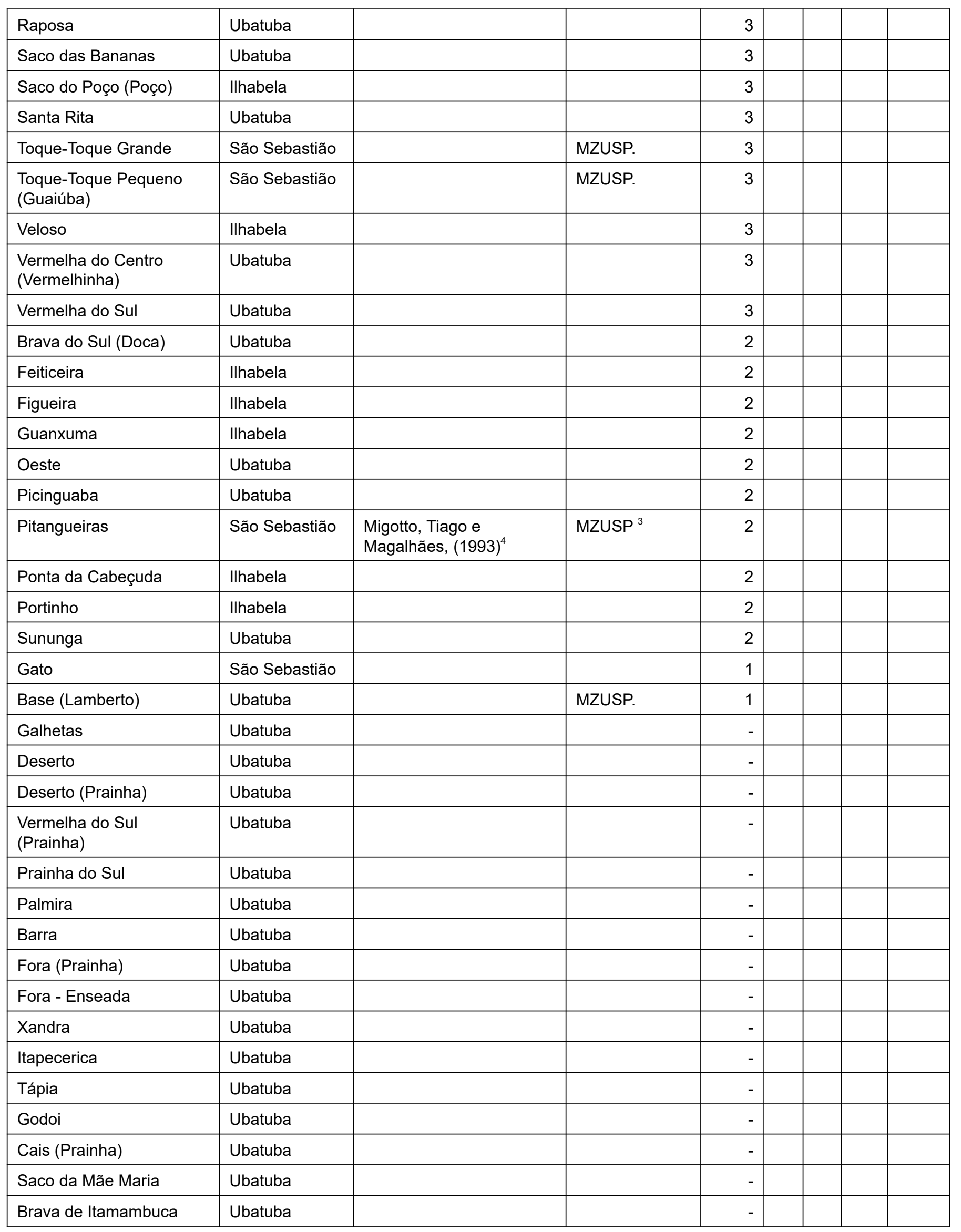

3 The specimens in this paper and this collection entry have very similar field information, so they may be from the same survey 


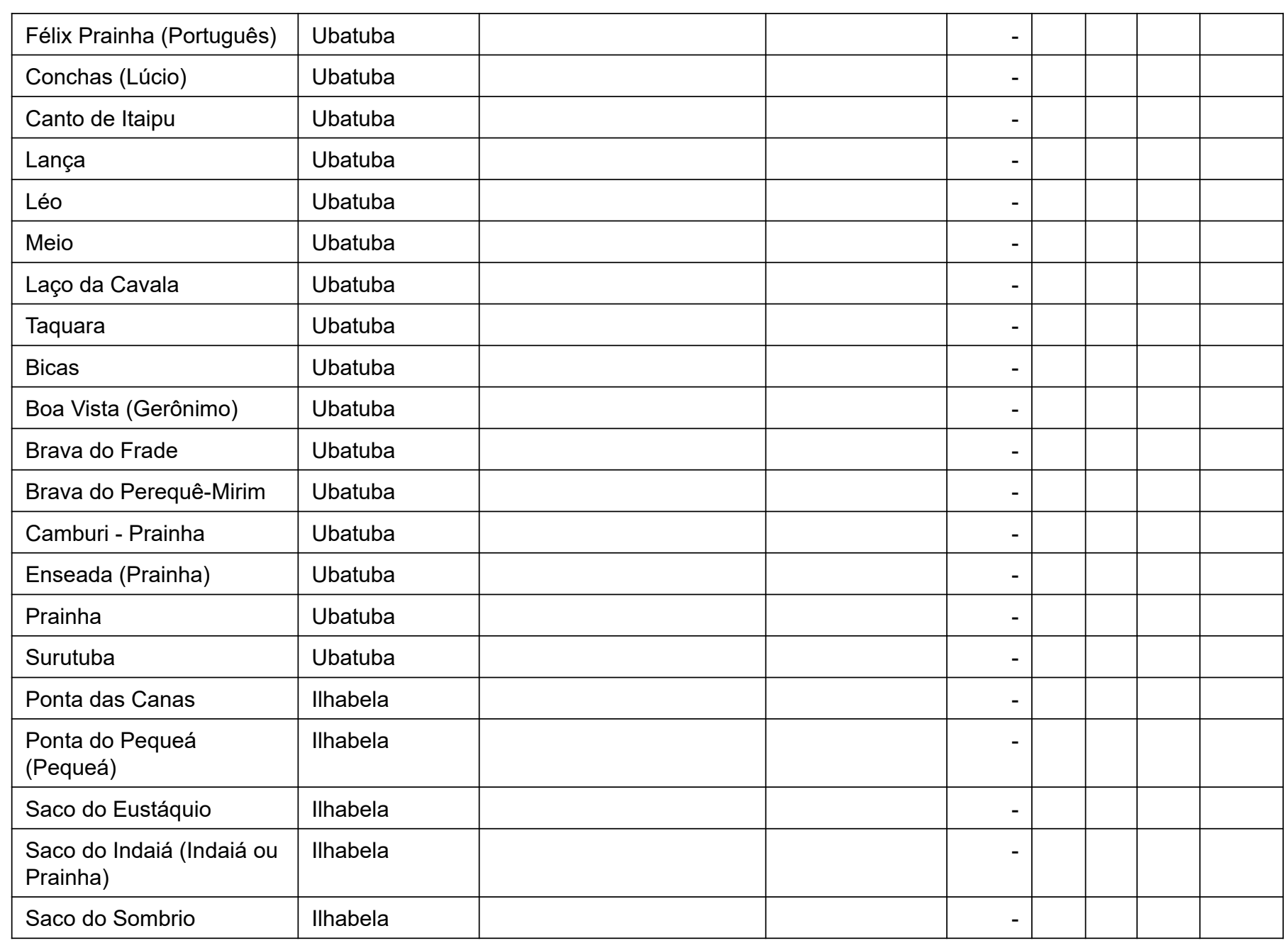




\section{ANNEX 7}

Most recent year of the records or evidence of Tivela mactroides for each one of the beaches. Last records includes literature review and collection records, while last evidence consists of interviews with experts, citizen science, interviews with community members and shell observation.

\begin{tabular}{|c|c|c|c|c|}
\hline Beach & Municipality & $\begin{array}{c}\text { Last } \\
\text { Record }\end{array}$ & $\begin{array}{c}\text { Last } \\
\text { Evidence }\end{array}$ & $\begin{array}{l}>20 \text { years } \\
\text { (before } \\
1998)\end{array}$ \\
\hline $\begin{array}{l}\text { Enseada de Caraguatatuba } \\
\text { (Enseada, Porto Novo/Palmeiras, } \\
\text { Flecheiras, Centro, Pan-Brasil, } \\
\text { Indaiá, Romance, Camaroeiros) }\end{array}$ & $\begin{array}{l}\text { São Sebastião } \\
\text { Caraguatatuba }\end{array}$ & 2015 & 2018 & No \\
\hline Fazenda & Ubatuba & 2004 & 2018 & No \\
\hline Preta (Costa Sul) & São Sebastião & & 2018 & No \\
\hline Baleia & São Sebastião & 1995 & 2018 & No \\
\hline Barequeçaba (Baraqueçaba) & São Sebastião & 2011 & 2018 & No \\
\hline Boracéia & São Sebastião & & 2018 & No \\
\hline Engenho & São Sebastião & & 2018 & No \\
\hline Enseada & Ubatuba & 1995 & 2018 & No \\
\hline Estaleiro do Padre & Ubatuba & & 2018 & No \\
\hline Itaguá & Ubatuba & 1989 & 2018 & No \\
\hline Lagoinha & Ubatuba & - & 2018 & No \\
\hline Toninhas & Ubatuba & - & 2018 & No \\
\hline Ubatumirim & Ubatuba & 1994 & 2018 & No \\
\hline Alto & Ubatuba & & 2018 & No \\
\hline Barra do Sahy & São Sebastião & & 2018 & No \\
\hline Bonete & Ilhabela & 2014 & 1980's & No \\
\hline Brava da Almada & Ubatuba & & 2018 & No \\
\hline Cambury & São Sebastião & & 2018 & No \\
\hline Dura & Ubatuba & 1968 & 2018 & No \\
\hline Engenho & Ubatuba & & 2018 & No \\
\hline Félix & Ubatuba & & 2018 & No \\
\hline Fortaleza & Ubatuba & & 2018 & No \\
\hline Grande & Ubatuba & 1988 & 2018 & No \\
\hline Itamambuca & Ubatuba & & 2018 & No \\
\hline Juquehy & São Sebastião & & 2018 & No \\
\hline Maranduba & Ubatuba & & 2018 & No \\
\hline Perequê-Açú & Ubatuba & 2000 & 2017 & No \\
\hline Armação & Ilhabela & - & & No \\
\hline Barra do Una & São Sebastião & 1978 & & Yes \\
\hline Barra Seca & Ubatuba & 2011 & & No \\
\hline Barra Velha & Ilhabela & & 2018 & No \\
\hline
\end{tabular}




\begin{tabular}{|c|c|c|c|c|}
\hline Barreiros & Ilhabela & - & & Unknown \\
\hline Camburi & Ubatuba & & 2018 & No \\
\hline Engenho d'Água (Pequeá) & Ilhabela & - & & Unknown \\
\hline Enseada do Araçá & São Sebastião & 2012 & & No \\
\hline Garapucaia (Pedra do Sino) & Ilhabela & 2000 & & No \\
\hline $\begin{array}{l}\text { Grande (Balneário dos } \\
\text { Trabalhadores) }\end{array}$ & São Sebastião & - & 2018 & No \\
\hline Itaguaçu & Ilhabela & 2000 & & No \\
\hline Lagoa & Ubatuba & & 2016 & No \\
\hline Maresias & Caraguatatuba & & 2018 & No \\
\hline Martim de Sá & Caraguatatuba & 1988 & & Yes \\
\hline Paúba & São Sebastião & 2010 & & No \\
\hline Ponta Aguda & Ubatuba & & 2016 & No \\
\hline Saco da Ribeira & Ubatuba & 1967 & 1985 & Yes \\
\hline Perequê-mirim & Ubatuba & & 1980 & \\
\hline Tabatinga & Caraguatatuba & & 2016 & No \\
\hline Timbó (Zimbro) & São Sebastião & 1983 & & Yes \\
\hline Vila & Ilhabela & - & & Unknown \\
\hline Cocanha & Caraguatatuba & & 2016 & No \\
\hline Domingas Dias & Ubatuba & 1969 & & Yes \\
\hline Grande & Ilhabela & 2000 & & No \\
\hline Lázaro & Ubatuba & 1994 & 2018 & No \\
\hline Perequê-mirim & Ubatuba & & 2018 & No \\
\hline Massaguaçu & Caraguatatuba & 2001 & & No \\
\hline Mococa & Caraguatatuba & 1968 & 2018 & No \\
\hline Toque-Toque Grande & São Sebastião & - & & Unknown \\
\hline Toque-Toque Pequeno (Guaiúba) & São Sebastião & - & & Unknown \\
\hline Pitangueiras & São Sebastião & 1996 & & Yes \\
\hline Lamberto & Ubatuba & 1962 & & Yes \\
\hline
\end{tabular}




\section{ANNEX 8}

Every beach by each Simplified Habitat Suitability (SHS) category, organized by municipality for clarity.

\begin{tabular}{|c|c|c|}
\hline $\begin{array}{l}\text { Standard } \\
\text { Habitat } \\
\text { Suitability }\end{array}$ & Municipality & Beach \\
\hline \multirow[t]{2}{*}{7} & Ubatuba & Fazenda \\
\hline & $\begin{array}{l}\text { Caraguatatuba } \\
\text { São Sebastião }\end{array}$ & $\begin{array}{l}\text { Caraguatatuba Bay (Enseada, Porto Novo/Palmeiras, Flecheiras, Centro, Pan-Brasil, Indaiá, } \\
\text { Romance, Camaroeiros) }\end{array}$ \\
\hline \multirow[t]{2}{*}{6} & Ubatuba & Lagoinha; Enseada; Toninhas; Tenório; Itaguá; Ubatumirim; Estaleiro do Padre; Almada \\
\hline & São Sebastião & Baleia; Barequeçaba; Boracéia; Engenho. \\
\hline \multirow[t]{4}{*}{5} & Ubatuba & $\begin{array}{l}\text { Maranduba; Dura; Grande; Cedro (Cedrinho); Perequê-Açú; Alto; Itamambuca; Félix; Engenho; } \\
\text { Brava da Almada; Brava do Camburi; Fortaleza }\end{array}$ \\
\hline & Caraguatatuba & Freira (Garcez) \\
\hline & São Sebastião & $\begin{array}{l}\text { Juquehy; Conchas; Barra do Sahy; Cambury; Brava de Boiçucanga; Calhetas; Brava de Guaecá; } \\
\text { Centro; Porto Grande }\end{array}$ \\
\hline & Ilhabela & Castelhanos; Eustáquio; Bonete \\
\hline \multirow[t]{4}{*}{4} & Ubatuba & $\begin{array}{l}\text { Figueira; Ponta Aguda; Mansa; Lagoa; Simão (Brava do Frade); Caçandoquinha; Sapê; Grande } \\
\text { do Bonete; Cedro do Sul; Brava da Fortaleza; Costa; Sete Fontes; Flamenguinho; Flamengo; } \\
\text { Dionísia; Saco da Ribeira; Barra Seca Vermelha do Norte Puruba Camburi }\end{array}$ \\
\hline & Caraguatatuba & Prainha; Martim de Sá; Tabatinga. \\
\hline & São Sebastião & $\begin{array}{l}\text { Brava da Boracéia; Juréia; Barra do Una; Havaizinho; Camburizinho; Maresias; Paúba; Santiago; } \\
\text { Guaecá; Segredo; Timbó (Zimbro); Grande (Balneário dos Trabalhadores); Enseada do Araçá; } \\
\text { Deserta; Pontal da Cruz; Arrastão; Portal da Olaria; São Francisco; Cigarras; Figueira. }\end{array}$ \\
\hline & Ilhabela & $\begin{array}{l}\text { Engenho d'Água (Pequeá); Pedras Miúdas; Armação; Itaquanduba; Garapucaia (Pedra do Sino); } \\
\text { Barra Velha; Barreiros; Caveira; Fome; Indaiaúba; Julião; Pacuíba; Ponta Azeda; Saco da } \\
\text { Capela; Santa Teresa; Serraria. }\end{array}$ \\
\hline \multirow[t]{4}{*}{3} & Ubatuba & $\begin{array}{l}\text { Raposa; Saco das Bananas; Caçandoca; Pulso; Peres; Bonete (Bonetinho); Vermelha do Sul; } \\
\text { Domingas Dias; Lázaro; Codó; Perequê-Mirim; Santa Rita; Vermelha do Centro (Vermelhinha); } \\
\text { Iperoig (Cruzeiro) (Centro). }\end{array}$ \\
\hline & Caraguatatuba & Brava; Massaguaçu; Capricórnio; Cocanha; Mococa \\
\hline & São Sebastião & $\begin{array}{l}\text { Preta (Centro) Boiçucanga Toque-Toque Pequeno (Guaiúba) Toque-Toque Grande Preta (Centro) } \\
\text { Cabelo Gordo }\end{array}$ \\
\hline & Ilhabela & Curral; Enchovas (Anchovas); Grande; Oscar; Saco do Poço (Poço); Veloso \\
\hline \multirow[t]{3}{*}{2} & Ubatuba & Brava do Sul (Doca); Sununga; Picinguaba; Oeste \\
\hline & São Sebastião & Pitangueiras \\
\hline & Ilhabela & Feiticeira; Figueira; Guanxuma; Ponta da Cabeçuda; Portinho \\
\hline \multirow[t]{2}{*}{1} & Ubatuba & Lamberto \\
\hline & Ilhabela & Gato \\
\hline \multirow[t]{2}{*}{ - } & Ilhabela & Ponta das Canas; Ponta do Pequeá; Saco do Eustáquio; Saco do Indaiá; Saco do Sombrio \\
\hline & Ubatuba & $\begin{array}{l}\text { Galhetas; Deserto; Deserto (Prainha); Vermelha do Sul (Prainha); Prainha do Sul; Palmira; Barra; } \\
\text { Fora; Fora - Enseada; Xandra; Itapecerica; Tápia; Godoi; Cais; Saco da Mãe Maria; Brava de } \\
\text { Itamambuca; Félix Prainha (Português); Conchas (Lúcio); Canto de Itaipu; Lança; Léo; Meio; } \\
\text { Laço da Cavala; Taquara; Bicas; Boa Vista (Gerônimo); Brava do Frade; Brava do Perequê- } \\
\text { Mirim; Camburi - Prainha; Enseada (Prainha); Prainha; Surutuba }\end{array}$ \\
\hline
\end{tabular}




\section{ANNEX 9}

Table showing the experts, by institution, with the method they were discovered/ contacted and the reason they where considered experts. Acronyms used in this table: USP - Universidade de São Paulo; UNICAMP - Universidade de Campinas; UNIFESP - Universidade Federal de São Paulo; ETEC - Escola Técnica Estadual.

\begin{tabular}{|c|c|c|c|}
\hline Expert & Institution & Contact method & Why is this person an expert? \\
\hline 1 & USP & $\begin{array}{l}\text { Identified through } \\
\text { literature }\end{array}$ & Author of papers about Tivela mactroides \\
\hline 2 & USP & Snowball & Author of papers about Tivela mactroides \\
\hline 3 & UNICAMP & Snowball & Author of papers about Tivela mactroides \\
\hline 4 & USP & Snowball & Researcher of beach fauna in the region \\
\hline 5 & UNICAMP & Snowball & Researcher of beach fauna in the region \\
\hline 6 & USP & Snowball & Taxonomist and malacologist \\
\hline 7 & USP & Snowball & Researcher of beach fauna in the region \\
\hline 8 & UNIFESP & Snowball & Researcher of beach fauna in the region \\
\hline 9 & ETEC & Snowball & Researcher of the region \\
\hline
\end{tabular}


Interviews with community members, by location, organized from North to South, the method through which they were found, with dates and if they treat Tivela mactroides and Anomalocardia brasiliana. "Location" means that the interviewee was found during one the visits to the location and approached without previous reference.

\begin{tabular}{|c|c|c|c|c|}
\hline Interviewee & $\begin{array}{l}\text { Location where the } \\
\text { interview was } \\
\text { conducted }\end{array}$ & Date & $\begin{array}{l}\text { Contact } \\
\text { method }\end{array}$ & $\begin{array}{l}\text { Understands Tivela mactroides and } \\
\text { Anomalocardia brasiliana as the same } \\
\text { thing }\end{array}$ \\
\hline 1 & Fazenda & 09/04/2018 & Snowball & No \\
\hline 2 & Fazenda & 09/04/2018 & Snowball & No \\
\hline 3 & Ubatumirim & $30 / 08 / 2018$ & Snowball & Yes \\
\hline 4 & Perequê-açu & $31 / 08 / 2018$ & Location & Yes \\
\hline 5 & Perequê-açu & $31 / 08 / 2018$ & Snowball & Yes \\
\hline 6 & Perequê-açu & $31 / 08 / 2018$ & Location & Yes \\
\hline 7 & Perequê-açu & $31 / 08 / 2018$ & Snowball & Yes \\
\hline 8 & Ilha dos Pescadores & 20/07/2018 & Snowball & No \\
\hline 9 & Centro (Ubatuba) & 07/05/2018 & Snowball & No \\
\hline 10 & Centro (Ubatuba) & $23 / 07 / 2018$ & Snowball & No \\
\hline 11 & Itaguá & $11 / 04 / 2018$ & $\begin{array}{l}\text { Social } \\
\text { Media }\end{array}$ & Yes \\
\hline 12 & Itaguá & $31 / 08 / 2018$ & Snowball & Yes \\
\hline 13 & Itaguá & $31 / 08 / 2018$ & Snowball & Yes \\
\hline 14 & Itaguá & $10 / 08 / 2018$ & Snowball & No \\
\hline 15 & Base & $10 / 04 / 2018$ & Location & No \\
\hline 16 & Base & $10 / 04 / 2018$ & Snowball & Did not know \\
\hline 17 & Base & $24 / 08 / 2018$ & Snowball & No \\
\hline 18 & Base & $24 / 08 / 2018$ & Snowball & Yes \\
\hline 19 & Saco da Ribeira & $10 / 04 / 2018$ & Location & No \\
\hline 20 & Lázaro & 08/04/2018 & Location & No \\
\hline 21 & Lázaro & 08/04/2018 & Location & No \\
\hline 22 & Lázaro & 08/04/2018 & Snowball & Yes \\
\hline 23 & Lázaro & 08/04/2018 & Snowball & Yes \\
\hline 24 & Lázaro & $27 / 07 / 2018$ & Snowball & Yes \\
\hline 25 & Maranduba & $24 / 07 / 2018$ & Snowball & Yes \\
\hline 26 & Maranduba & 02/09/2018 & Location & No \\
\hline 27 & Tabatinga & 20/02/2018 & Location & No \\
\hline 28 & Camaroeiro & $20 / 02 / 2018$ & Location & Yes \\
\hline 29 & Camaroeiro & 20/02/2018 & Snowball & No \\
\hline 30 & Camaroeiro & 23/02/2018 & Location & Yes \\
\hline 31 & Indaiá & 20/07/2019 & Snowball & Yes \\
\hline 32 & Britânia & $01 / 12 / 2017$ & Location & No \\
\hline 33 & Porto Novo & $20 / 02 / 2018$ & Location & Yes \\
\hline 34 & Porto Novo & $20 / 02 / 2018$ & Location & No \\
\hline
\end{tabular}




\begin{tabular}{|c|c|c|c|c|}
\hline 35 & Porto Novo & $20 / 02 / 2018$ & Snowball & Yes \\
\hline 36 & Porto Novo & $20 / 02 / 2018$ & Location & Yes \\
\hline 37 & São Francisco & $21 / 02 / 2018$ & Location & Yes \\
\hline 38 & São Francisco & $21 / 02 / 2018$ & Location & Yes \\
\hline 39 & Cebimar & $20 / 07 / 2918$ & Snowball & No \\
\hline 40 & Barequeçaba & 04/09/2018 & Snowball & No \\
\hline 41 & Baleia & $10 / 09 / 2018$ & Location & Yes \\
\hline 42 & $\begin{array}{l}\text { Camburi (São } \\
\text { Sebastião) }\end{array}$ & $19 / 07 / 2018$ & Location & Yes \\
\hline 43 & Jabaquara & $22 / 02 / 2018$ & Location & Yes \\
\hline 44 & Jabaquara & $22 / 02 / 2018$ & Snowball & Yes \\
\hline 45 & Vila (Ilhabela) & $28 / 06 / 2018$ & Location & Yes \\
\hline 46 & Perequê & $28 / 06 / 2018$ & Location & Yes \\
\hline 47 & Portinho & $22 / 02 / 2018$ & Location & No \\
\hline 48 & Portinho & $29 / 06 / 2018$ & Snowball & Yes \\
\hline
\end{tabular}


Results from the Citizen Science effort, ordered chronologically, with the beach, name of the participants, the medium it was submitted, the day the picture was taken and coordinates (if known).

\begin{tabular}{|c|c|c|c|c|}
\hline Beach & Submitter & Media & Municipality & Day \\
\hline Porto Novo & Camila Luvizaro & Facebook & Caraguatatuba & $04 / 01 / 2018$ \\
\hline $\begin{array}{l}\text { do Costa (Lat -23,51631; } \\
\text { Long }-045,16582 \text { ) }\end{array}$ & Nagui Ubatuba & Facebook & Ubatuba & $13 / 01 / 2018$ \\
\hline Toninhas & Neto Ubatuba & WhatsApp & Ubatuba & $11 / 01 / 2018$ \\
\hline Porto Novo & Pedro Santos & Facebook & Caraguatatuba & $12 / 01 / 2018$ \\
\hline Fazenda & Cecília Amaral & WhatsApp & Ubatuba & $31 / 01 / 2018$ \\
\hline Ubatumirim & Neto Ubatuba & WhatsApp & Ubatuba & $02 / 02 / 2018$ \\
\hline Perequê-açu & Neto Ubatuba & WhatsApp & Ubatuba & $08 / 02 / 2018$ \\
\hline Guaecá & Debora Laura & WhatsApp & São Sebastião & $25 / 02 / 2018$ \\
\hline Barequeçaba & Gaby Podologa & Instagram & São Sebastião & $8 / 5 / 2018$ \\
\hline Indaia & Pedro Santos & Facebook & Caraguatatuba & $11 / 5 / 2018$ \\
\hline \begin{tabular}{|l|} 
Balneário dos \\
Trabalhadores
\end{tabular} & Tayná Pires & Instagram & São Sebastião & $22 / 5 / 2018$ \\
\hline Barequeçaba & Katherine Amorim & Facebook & São Sebastião & $26 / 5 / 2018$ \\
\hline Aruan & Victor Pugliese & Instagram & Caraguatatuba & $12 / 6 / 2018$ \\
\hline Ubatumirim & Marília Raganin & WhatsApp & Ubatuba & $12 / 6 / 2018$ \\
\hline Indaiá & Zenaide Nascimento & Instagram & Caraguatatuba & $13 / 6 / 2018$ \\
\hline Porto Novo & Zenaide Nascimento & Facebook & Caraguatatuba & $13 / 6 / 2018$ \\
\hline Fazenda & Marília Raganin & WhatsApp & Ubatuba & $14 / 6 / 2018$ \\
\hline Ubatumirim & Doris Satie Fontes & Instagram & Ubatuba & $15 / 6 / 2018$ \\
\hline Juquehy & Léa Ferro & Instagram & São Sebastião & $16 / 6 / 2018$ \\
\hline Ubatumirim & Doris Satie Fontes & Instagram & Ubatuba & $18 / 6 / 2018$ \\
\hline Barra do Sahy & Ligia Ungerer & Instagram & São Sebastião & $19 / 6 / 2018$ \\
\hline Guaecá & Zize Souza & Instagram & São Sebastião & $24 / 6 / 2018$ \\
\hline Barequeçaba & Luís Eugênio Moreira & Instagram & São Sebastião & $24 / 6 / 2018$ \\
\hline Ubatumirim & Doris Satie Fontes & Instagram & Ubatuba & $25 / 6 / 2018$ \\
\hline Barra do Sahy & Lê Macedo & Facebook & São Sebastião & $30 / 6 / 2018$ \\
\hline Barequeçaba & Elisabeth Goeritz & Facebook & São Sebastião & $8 / 7 / 2018$ \\
\hline Boracéia & Priscilla Waack & Facebook & São Sebastião & $13 / 7 / 2018$ \\
\hline Barequeçaba & Luís Eugênio Moreira & Instagram & São Sebastião & $14 / 7 / 2018$ \\
\hline Itaguá & Marimárcia de Moura & Instagram & Ubatuba & $15 / 7 / 2018$ \\
\hline Indaia & Debora Rose & Facebook & Caraguatatuba & $15 / 7 / 2018$ \\
\hline Toninhas & Ludgero Parolin Risaliti & Facebook & Ubatuba & $19 / 7 / 2018$ \\
\hline Palmeiras & Natasha Guedes Demars & Instagram & Caraguatatuba & $20 / 7 / 2018$ \\
\hline Palmeiras & Natasha Guedes Demars & Instagram & Caraguatatuba & $21 / 7 / 2018$ \\
\hline do Alto & Silvana Batista Penninck & Facebook & Ubatuba & $22 / 7 / 2018$ \\
\hline Barequeçaba & Luís Eugênio Moreira & Instagram & São Sebastião & $24 / 7 / 2018$ \\
\hline Palmeiras & Elaine Clemens Torres & Facebook & Caraguatatuba & $?$ \\
\hline Romance & Izilda Dernichanian & Facebook & Caraguatatuba & $24 / 7 / 2018$ \\
\hline Palmeiras & Izilda Dernichanian & Facebook & Caraguatatuba & $25 / 7 / 2018$ \\
\hline Juquehy & Léa Ferro & Instagram & São Sebastião & $1 / 9 / 2018$ \\
\hline Barra do Sahy & Léa Ferro & Instagram & São Sebastião & $1 / 9 / 2018$ \\
\hline Indaiá & Natasha Guedes Demars & Instagram & Caraguatatuba & $1 / 9 / 2018$ \\
\hline Barequeçaba & Luis Eugênio Moreira & Instagram & São Sebastião & $2 / 9 / 2018$ \\
\hline Palmeiras & Lenise Clemens & Facebook & Caraguatatuba & $21 / 9 / 2018$ \\
\hline Centro & Elisa van & WhatsApp & Caraguatatuba & $26 / 9 / 2018$ \\
\hline Camaroeiro & Jessica & Instagram & Caraguatatuba & $30 / 9 / 2018$ \\
\hline Centro & Natasha Guedes Demars & Instagram & Caraguatatuba & $3 / 10 / 2018$ \\
\hline Barra do Sahy & Léa Ferro & Instagram & São Sebastião & $13 / 10 / 18$ \\
\hline
\end{tabular}

